UNIVERSIDADE DE SÃO PAULO

FACULDADE DE ECONOMIA, ADMINISTRAÇÃO E CONTABILIDADE DEPARTAMENTO DE CONTABILIDADE E ATUÁRIA PROGRAMA DE PÓS-GRADUAÇÃO EM CIÊNCIAS CONTÁBEIS

\author{
A CONTABILIDADE A VALOR JUSTO \\ E A CRISE FINANCEIRA MUNDIAL
}

Autor: Eric Barreto

Orientador: Prof. Dr. Iran Siqueira Lima

SÃo PAULO 
Profa. Dra. Suely Vilela

Reitora da Universidade de São Paulo

Prof. Dr. Carlos Roberto Azzoni

Diretor da Faculdade de Economia, Administração e Contabilidade

Prof. Dr. Fábio Frezatti

Chefe do Departamento de Contabilidade e Atuária

Prof. Dr. Edgard Bruno Cornachionne

Coordenador do Programa de Pós-Graduação em Ciências Contabilidade 


\title{
ERIC BARRETO
}

\section{A CONTABILIDADE A VALOR JUSTO \\ E A CRISE FINANCEIRA MUNDIAL}

\begin{abstract}
Dissertação apresentada ao Departamento de Contabilidade e Atuária da Faculdade de Economia, Administração e Contabilidade da Universidade de São Paulo como requisito para a obtenção do título de Mestre em Ciências Contábeis.
\end{abstract}

Orientador: Prof. Dr. Iran Siqueira Lima

\section{SÃO PAULO}


Dissertação defendida e aprovada no Departamento de Contabilidade e Atuária da Faculdade de Economia, Administração e Contabilidade da Universidade de São Paulo - Programa de Pós-Graduação em Ciências Contábeis, pela seguinte banca examinadora:

\section{FICHA CATALOGRÁFICA}

Elaborada pela Seção de Processamento Técnico do SBD/FEA/USP

\section{Barreto, Eric}

A contabilidade a valor justo e a crise financeira mundial / Eric Barreto.

-- São Paulo, 2009.

$145 \mathrm{p}$.

Dissertação (Mestrado) - Universidade de São Paulo, 2009. Bibliografia.

1. Valor (Contabilidade) 2. Crise financeira 3. Crise Bancária

4. Contabilidade Internacional I. Universidade de São Paulo. Faculdade de Economia, Administração e Contabilidade II. Título.

CDD -657.013 
Dedico este trabalho aos meus pais, sempre os primeiros a acreditar, e também às mulheres da minha vida, Tathiana e Sophia. 
Após cerca de 30 meses de trabalho, créditos concluídos, dissertação concluída, são muitos a quem agradecer, mas devo limitar-me a estas duas páginas, para não exceder em muito a recomendação da Universidade para esta seção do trabalho.

Não poderia deixar de começar pelo Professor Dr. Iran Siqueira Lima, que além de assumir a orientação deste trabalho, já havia me orientado na monografia de graduação, e foi um dos principais responsáveis por eu ter alterado o rumo da minha carreira, ingressando no Programa de Pós-Graduação em Ciências Contábeis da FEA-USP.

No período de graduação, lembro o quanto ele era temido... Professor Dr. Nelson Carvalho. Ao contrário do que pensa quem vê sua aparência séria, é uma figura carismática e solícita. Devo a ele a escolha do tema deste trabalho, muitos conselhos profissionais e o apoio fundamental para que eu conseguisse um grupo tão especial de entrevistados.

Pela amizade e disponibilidade fora do período de aula, agradeço ao simpático Professor Dr. Luiz João Corrar, e também ao Professor Dr. Gerlando Augusto S. F. de Lima.

Outro entre os "temidos" da graduação, o corinthiano (ninguém é perfeito) Professor Dr. Ariovaldo dos Santos, merece destaque pela didática e pelo bom humor. E, por falar em didática e bom humor, nada mais justo que lembrar da oportunidade que tive ao ser aluno do Professor Dr. Eliseu Martins, um exemplo para todos da nossa profissão.

Também agradeço ao Professor Dr. Bruno Meirelles Salotti, que participou e forneceu grandes ideias no momento de concepção deste trabalho, e ao Professor Dr. Fábio Moraes da Costa, que me ajudou com o "acabamento" da pesquisa.

Os professores Dr. Edgard Bruno Cornachione e Dr. Gilberto de Andrade Martins colaboraram em uma fase em que a metodologia de pesquisa era necessária para que boas ideias não se dispersassem no emaranhado de atividades a realizar.

Entre tantos outros professores que mereciam ser lembrados, destaco Edson Luiz Riccio, Reinaldo Guerreiro, Vinicius Aversari Martins, Fábio Frezatti, Welington Rocha e Lázaro Plácido Lisboa, que contribuíram com meu aprendizado nos anos de graduação e/ou pós.

Entre os colegas discentes, aqueles que mais contribuíram para aumentar meus conhecimentos sobre a contabilidade e a vida: Camila, Michelly, Cynthia, Castilho, Carlos Quinteiro e Bleise, Ricardo, Daniel, Edilmar, Maurício, Ludwig, Aldomar, Bruna, Gustavo, Sérgio Mendel, Hugo, Murcia, Artur, Ana Luísa, Cris Benetti, Luciane, José Elias, Jesusmar, Eric Martins, Felipe Garran, Fabiano Gabriel, Renato, Simone e Guillermo. 
Entre as instituições, agradeço pelo apoio e estrutura da FIPECAFI e do Departamento de Contabilidade da FEA-USP e às suas equipes.

Profissionalmente, abrimos mão de muitas oportunidades quando decidimos nos dedicar a um curso de Mestrado ou Doutorado. Mesmo assim, muitos estiveram por perto para assistir a essas decisões. Agradeço aos amigos da SAP Brasil, em especial Valentim, Ciro, Bujes, Giam, Domingos, Bassi, Luis Arouche, Kaway, Cacalis e José Almeida; às amigas Adriana e Márcia, da Complex, aos amigos Giuliano, Belentani, Bayarri, Pinotti, Marco Tulio, Julia Vilac, Forti e outros, da Finity; à equipe de Financial Services e aos amigos Elizeu, Naéde, Élcio, Morales, Merkison, Manolo e Dirk, da Politec; à Família Pinheiro e todos do Banco Pine; aos amigos da Lógica e Tixy, em especial Rafael e Luis Fagundes; aos muitos amigos que passaram pela Matera Systems; auditores do antigo BankBoston; auditores e consultores da Deloitte; consultores da Accenture e da IBM; Renato Barros, Claudia Pavani, Léo e Bandeira, da Kiman Solutions; e aos novos amigos do Grupo FBM. Não poderia deixar de lembrar dos meus clientes e ex-clientes do Banco Schahin, Standard Bank, HSBC, Riachuelo, Lojas Marisa, Banco Ibi, Banco CR2, Bic Banco, JP Morgan, Credicard, Orbitall, Banco Carrefour, CNH Capital, UBS, Cetelem, HP Leasing, Banif, Banco Ficsa, Banco Prosper, Tribanco, Banco BMC, Banco Cruzeiro do Sul, Banco da Amazônia, Itaú-Unibanco, Unicred, Santander, antigos Bank of America, Fininvest, Hedging-Griffo e Wachovia.

Também agradeço aos coordenadores e alunos da Faculdade Sumaré, Fecap, pósgraduação da UniÍtalo, Mackenzie e Fipecafi.

Fora da academia, agradeço e dedico este trabalho a toda minha família e amigos, em especial Thays, Diego, Maria Fernanda e Nando, e aos amigos Leandro, Joe, Pace e Franco. Por fim, agradeço infinitamente aos ilustres economistas e grandes conhecedores do mercado que contribuíram com este trabalho: Marcos Eugênio da Silva, Hélio Nogueira da Cruz, Alkimar Moura, Gustavo Loyola, Clive Botelho, Roberto Padovani, Gustavo Franco, Ilan Goldfajn, Mailson da Nóbrega, Maria Helena Santana, Arminio Fraga, Teresa Grossi e Delfim Netto. Sem eles, este trabalho não teria sido possível. Com seu brilho, aumentaram as chances de sucesso de um novo pesquisador. 
"Enquanto a música estiver tocando, é preciso se levantar e dançar". Chuck Prince, ex-presidente-executivo do Citigroup 


\section{RESUMO}

A contabilidade a valor justo tem sido discutida desde meados do século passado; porém, tomou força maior a partir de publicações recentes do FASB (Financial Accounting Standards Board) e do IASB (International Accounting Standards Board). Mais recentemente, em resposta à crise global de 2008, inicialmente chamada de "crise do subprime", a SEC (Securities Exchange Comission), o FASB e o IASB rediscutiram exaustivamente este critério de mensuração, com o objetivo de detectar falhas que poderiam ter deflagrado ou agravado a crise, e também a fim de esclarecer como o valor justo deve ser estimado no caso de mercados ilíquidos ou ausência de um mercado ativo.

Esta dissertação questiona se, na visão de especialistas em economia e mercado financeiro, a contabilidade a valor justo teve papel decisivo na deflagração ou agravamento da crise financeira mundial.

A primeira parte deste trabalho se desenvolve primariamente com base nos pronunciamentos do IASB e do FASB sobre o valor justo na contabilidade, e tem por finalidade a revisão de alguns conceitos sobre mensuração e, principalmente, buscar o entendimento da teoria e da aplicabilidade da contabilidade baseada em valores de mercado. Na segunda parte, são estudadas diferentes teorias sobre a crise, culminando no assunto "a contabilidade e a crise financeira mundial”. A parte empírica do trabalho consiste na realização de entrevistas com grandes especialistas em economia e mercado financeiro.

O estudo é concluído com base não só nas entrevistas, mas também nos estudos recentes da SEC, do IASB e do FASB, e na literatura sobre a crise, que evidenciam que, entre diversos fatores que podem ter levado o mundo a esta crise, a contabilidade a valor justo teve papel pouco relevante. Pelo contrário, ainda colaborou com um diagnóstico mais rápido. 


\begin{abstract}
The fair value accounting has been discussed since the middle of last century, however, it became stronger after recent publications of FASB (Financial Accounting Standards Board) and IASB (International Accounting Standards Board). More recently, in response to the global crisis of 2008, initially called as "subprime crisis", SEC (Securities Exchange Commission), FASB and IASB have rediscussed a lot this measurement criterion, with the objective of detecting flaws that could have started off or worsened the crisis, and also explain how the fair value should be estimated in case of non-liquid markets or in the absence of an active market.

This dissertation asks, from economy and financial market specialists point of view, if the fair value accounting had a decisive role in the explosion or in the aggravation of the global crisis. The first part of this job is developed primarily based on IASB and FASB pronouncements about fair value accounting, with the purpose of reviewing some concepts about measurement and, mainly, look for an understanding of the theory and applicability of an accounting based on market values. In the second part, different theories about crisis are studied, culminating in the subject "fair value accounting and the global crisis". The empiric part of the job consists of interviews with great specialists in economy and financial market.

The study is concluded based not only on the interviews, but also on the recent studies of SEC, IASB and FASB, and on the literature about crisis, that evidence that, among several factors that might have led the world to this crisis, the fair value accounting had a small relevant role. Instead, the fair value collaborated yet with a faster diagnosis.
\end{abstract}




\section{SUMÁRIO}

GLOSSÁRIO DE TERMOS TÉCNICOS .....................................................................

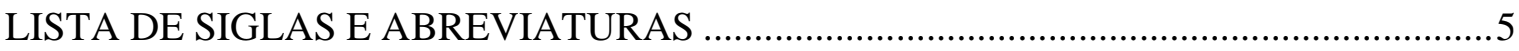

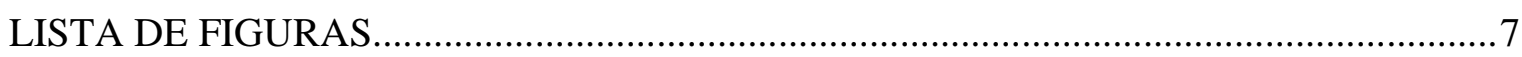

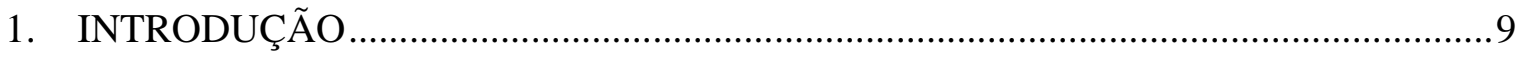

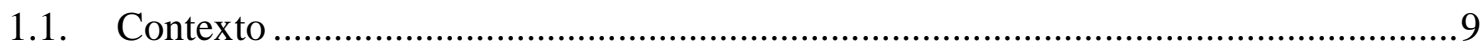

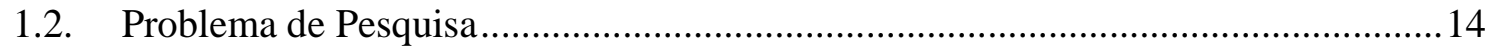

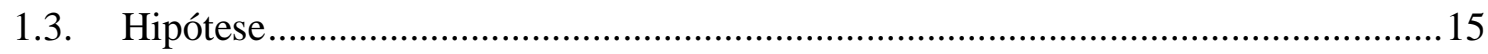

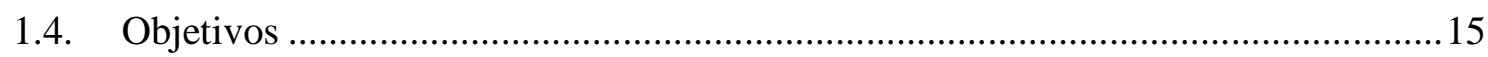

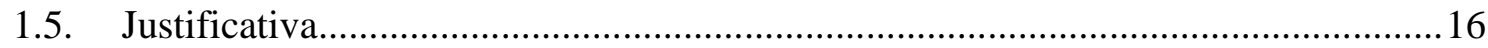

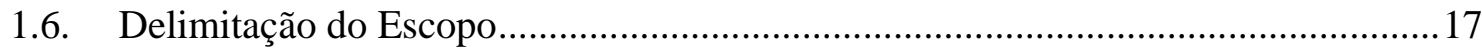

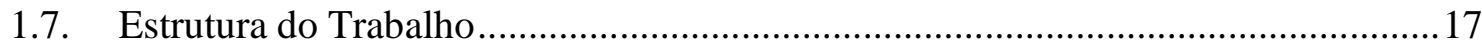

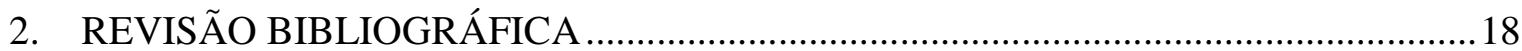

2.1. MENSURAÇÃO DE ATIVOS E PASSIVOS....................................................... 18

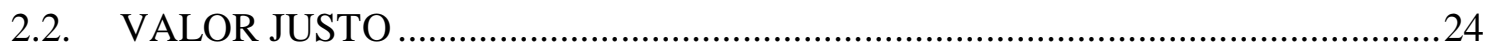

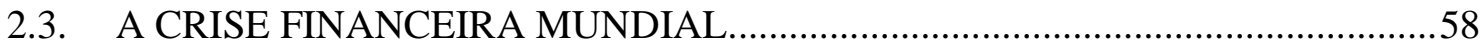

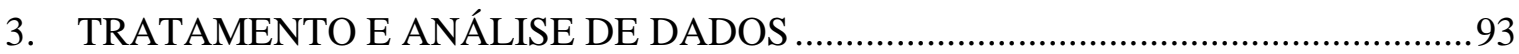

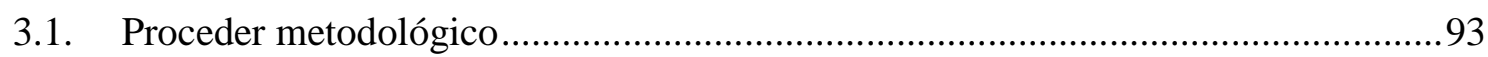

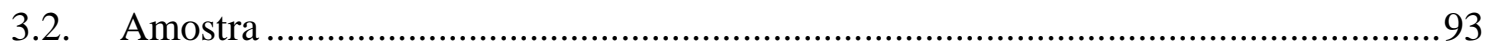

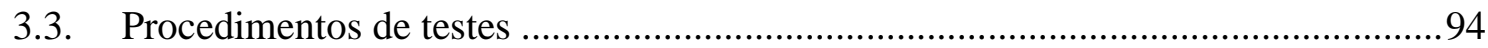

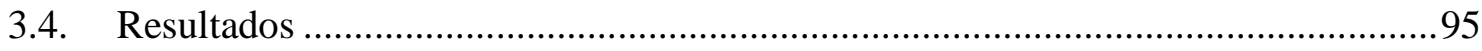

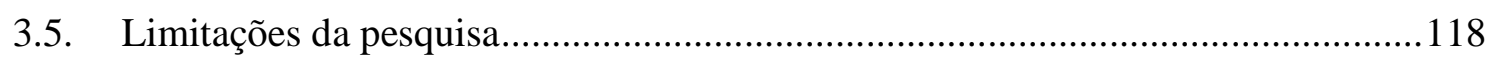

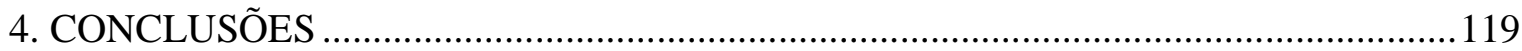

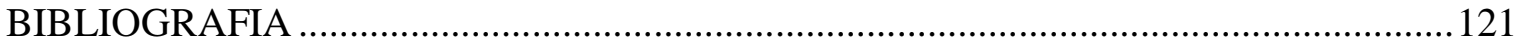

APÊNDICE A - CURRICULUM RESUMIDO DOS ENTREVISTADOS ........................127

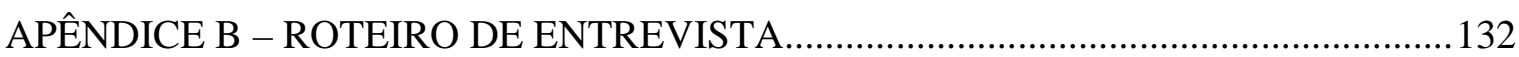




\section{GLOSSÁRIO DE TERMOS TÉCNICOS}

Acordos de Basileia: os países do G10 (Bélgica, Canadá, França, Alemanha, Itália, Japão, Luxemburgo, Holanda, Suécia, Suíça, Reino Unido e Estados Unidos), percebendo que a fragilidade do sistema bancário poderia ameaçar a estabilidade financeira interna e externa, redigiram, em 1988, na cidade de Basileia, Suíça, o primeiro acordo visando assegurar um nível adequado de capital no sistema bancário internacional. Em junho de 2004, foi publicado o segundo acordo, conhecido como Basileia II.

Agências de rating: são entidades contratadas por emissores de títulos de dívida ou patrimoniais para avaliar ativos específicos ou a própria companhia. Os investidores e potenciais investidores são usuários das análises preparadas pelas agências de classificação de risco.

Ato: Ato de Estabilização Econômica Emergencial de 2008.

Carta de fiança: a carta de fiança é um tipo de garantia, normalmente prestada por um banco a um cliente que, em contrapartida, paga uma comissão de fiança. Se o cliente não honrar a dívida que está vinculada a esta carta de fiança, o banco, prestador da garantia, é obrigado a efetuar o pagamento no lugar do cliente. Caso o cliente não deixe de pagar seu compromisso, o banco simplesmente recebe sua comissão.

Commercial Papers: valores mobiliários de curto prazo, valores e vencimentos fixos, de emissão de sociedade anônima. Trata-se de uma nota promissória não garantida, ou seja, o risco de inadimplência é o risco de crédito do emissor da nota.

Discussion Paper: documento técnico que é colocado em discussão pelo FASB ou pelo IASB, precedendo a publicação de um Exposure Draft.

Derivativos - instrumentos financeiros cujos preços dependem de outro ativo, denominado ativo objeto. Os derivativos mais comuns são os swaps, as opções e as operações de futuros.

Duration: é o prazo médio entre o reconhecimento inicial e o vencimento de uma classe de ativos ou passivos. Por exemplo: em determinado banco, o duration das operações de CDC Veículos é de 15 meses. Significa que, independentemente do prazo original pelo qual as operações são negociadas, o prazo médio desse ativo específico no banco é de 15 meses.

Exposure Draft: documento técnico que precede a publicação de uma norma do FASB ou do IASB. 
Factoring: mecanismo de fomento mercantil que possibilita à empresa fomentada vender seus créditos, gerados por suas vendas a prazo, a uma empresa de Factoring.

Futuros: derivativos que se assemelham a uma operação por encomenda liquidada em parcela única; porém, somente os preços do ativo são negociados, pois não ocorre entrega física.

Hedge Funds: fundos de investimento que podem utilizar uma imensa gama de técnicas e estratégias para obter retorno positivo, independentemente da conjuntura econômica ou da evolução dos mercados.

Impairment: o termo tem sido traduzido para a língua portuguesa como imparidade. Trata-se da redução dos ativos ao seu valor recuperável.

Instrumentos de equities: instrumentos patrimoniais.

Keynesiana: relativo a John Maynard Keynes, economista.

Laissez faire: princípio defendido pelos liberalistas, no qual o Estado deveria interferir o mínimo possível nas atividades econômicas, deixando o mercado evoluir livremente.

Maturity: vencimento.

Mercados de balcão: são mercados onde são negociados instrumentos financeiros padronizados e não padronizados, fora do ambiente das Bolsas.

Opções: derivativos que oferecem ao seu titular a opção de comprar ou vender por um preço prédeterminado o ativo objeto da opção. Para obter esse direito, o titular paga um prêmio ao lançador da opção, que tem a obrigação de comprar ou vender o ativo, caso a opção seja exercida. Operações off-balance sheet: são operações não contabilizadas, fora do balanço.

Rating: classificação de crédito de uma entidade. Nota atribuída por um banco, empresa de classificação ou outra entidade para identificar o nível de confiança e a capacidade de pagamento de uma entidade.

Report and Recommendations Pursuant to Section 133 of the Emergency Economic Stabilization Act: Ato de Estabilização Econômica Emergencial de 2008 ("EESA” ou o “Ato”).

Securitização: processo estruturado através do qual ativos financeiros ou não-financeiros são "empacotados" em forma de títulos, os quais podem ser vendidos a investidores interessados.

Schumpeteriana: relativa ao economista Joseph Schumpeter, que desenvolveu, entre outras, teorias sobre ciclos econômicos e desenvolvimento.

Subprime: créditos de segunda linha. Segmento que acolhe mutuários com problemas de crédito recentes, ou que gastam quantia significativa com o serviço da dívida. 
Swaps: derivativos que têm como finalidade a troca de indexadores de fluxo de caixa. Cada uma das partes da operação "aposta" um valor base em um indexador, fica "ativo" nesse indexador e "passivo" no indexador da sua contraparte. No vencimento da operação, o participante recebe (ou paga) a diferença entre o valor base corrigido pelo indexador ativo e o valor base corrigido pelo indexador passivo.

Técnicas de Valuation: técnicas de avaliação utilizadas para estimar o valor de ativos que não possuem cotação em um mercado ativo.

Trading: negociação. 


\section{LISTA DE SIGLAS E ABREVIATURAS}

ABCP: Asset-Backed Commercial Paper

AFS: Available for Sale ou disponível para a venda

BCB: Banco Central do Brasil

BOVESPA: Bolsa de Valores do Estado de São Paulo

BRIC: grupo de países emergentes formado por Brasil, Rússia, Índia e China

CFA Institute: Chartered Financial Analyst

CPC: Comitê de Pronunciamentos Contábeis

CDO: Collateralized Debt Obligations. Ver seção 2.3.5

CDS: Credit Default Swap. Ver seção 2.3.5

FASB: Financial Accounting Standards Board

Fed: Federal Reserve System, o Banco Central Americano

FMI: Fundo Monetário Internacional

FSF: Financial Stability Forum

FVTPL: Fair Value Through Profit and Loss ou Valor justo através dos resultados

HFI: Held for Investment ou Mantidos para fins de investimento

HFS: Held for Sale ou Mantidos para venda

HTM: Held to Maturity ou Mantidos até o vencimento

IAS: International Accounting Standards

IASB: International Accounting Standards Board

IBRE - Instituto Brasileiro de Economia da FGV

IEPECDG - Instituto de Estudos e Pesquisas Econômicas Casa das Garças

IPCA: Índice de Preços ao Consumidor Amplo

IFRS: International Financial Reporting Standards

L\&R: Loans and Receivables ou Empréstimos e Recebíveis

OCI - Other Comprehensive Income ou Outros resultados compreensivos

PCLD: Provisão para Créditos de Liquidação Duvidosa

PDS: Portfolio Default Swap. Ver seção 2.3.5

SEC: Securities Exchange Comission 
SFAC: Statement of Financial Accounting Concepts

SFAS: Statement of Financial Accounting Standards

SIV: Structured Investment Vehicles ou Veículos de Investimento Estruturados

SUSEP: Superintendência de Seguros Privados

USGAAP: United States Generally Accepted Accounting Practices

VaR (Value at Risk Value at Risk): A técnica do valor em risco foi um dos primeiros modelos utilizados pelas instituições financeiras

VIX: Chicago Board Options Exchange Volatility Index 


\section{LISTA DE FIGURAS}

\begin{tabular}{|c|c|}
\hline Figura 1 & Proporção de ativos contabilizados pelo valor justo, ao final de 2007 \\
\hline Figura 2 & Proporção de ativos mensurados ao valor justo, ao final do primeiro trimestre de 2008 \\
\hline Figura 3 & Proporção de ativos mensurados ao valor justo por indústria, ao final do primeiro trimestre de 2008 \\
\hline Figura 4 & Proporção de ativos mensurados ao valor justo por tamanho, ao final do primeiro trimestre de 2008 \\
\hline Figura 5 & Percentual de passivos mensurados ao valor justo \\
\hline Figura 6 & Percentual de passivos mensurados ao valor justo por tamanho da entidade \\
\hline Figura 7 & Hierarquia Fair Value \\
\hline Figura 8 & $\begin{array}{l}\text { Classificação de ativos mensurados ao valor justo, de acordo com a hierarquia do valor justo, ao final } \\
\text { do primeiro trimestre de } 2008\end{array}$ \\
\hline Figura 9 & Classificação de ativos ao valor justo, de acordo com a hierarquia do valor justo \\
\hline Figura 10 & $\begin{array}{l}\text { Classificação de passivos mensurados ao valor justo, de acordo com a hierarquia do valor justo, ao } \\
\text { final do primeiro trimestre de } 2008\end{array}$ \\
\hline Figura 11 & Utilidade da informação contábil \\
\hline Figura 12 & Modelo de divulgação do valor justo de instrumentos financeiros em um banco \\
\hline Figura 13 & Modelo de divulgação do valor justo de instrumentos financeiros em uma instituição não-financeira \\
\hline Figura 14 & $\begin{array}{l}\text { Percentual de ativos para os quais as mudanças no valor justo afetam o resultado, comparado com } \\
\text { aqueles que não afetam o resultado e com outros que não são mensurados pelo valor justo, ao final do } \\
\text { primeiro trimestre de } 2008\end{array}$ \\
\hline Figura 15 & Fair value option de ativos financeiros \\
\hline Figura 16 & Fair value option de passivos financeiros \\
\hline Figura 17 & Natureza de passivos mensurados ao valor justo \\
\hline Figura 18 & Natureza dos ativos mensurados ao valor justo \\
\hline Figura 19 & Poupanças, investimentos e conta corrente dos países de alta renda \\
\hline Figura 20 & $\begin{array}{l}\text { Poupanças, investimentos e conta corrente dos mercados emergentes e dos países exportadores de } \\
\text { petróleo }\end{array}$ \\
\hline Figura 21 & Taxa de juros real de longo prazo do mundo \\
\hline Figura 22 & Evolução do VIX \\
\hline Figura 23 & Fluxo simplificado de uma CDO \\
\hline Figura 24 & Diagrama de uma CDO Sintética Simples \\
\hline Figura 25 & Evolução de várias formas de papel comercial \\
\hline Figura 26 & Bancos americanos falidos em 2008 \\
\hline Figura 27 & Empréstimos contabilizados pelo custo amortizado \\
\hline Figura 28 & Ativos e passivos mensurados recorrentemente pelo valor justo \\
\hline Figura 29 & $\begin{array}{l}\text { Investimentos em títulos (perdas no valor justo reconhecidas no resultado somente em casos de } \\
\text { impairment) }\end{array}$ \\
\hline Figura 30 & Ativos contabilizados pelo menor valor entre custo e valor justo \\
\hline Figura 31 & Empréstimos contabilizados pelo custo amortizado \\
\hline Figura 32 & Ativos e passivos mensurados recorrentemente pelo valor justo \\
\hline Figura 33 & $\begin{array}{l}\text { Investimentos em títulos (perdas no valor justo reconhecidas no resultado somente em casos de } \\
\text { impairment) }\end{array}$ \\
\hline Figura 34 & Ativos contabilizados pelo menor valor entre custo e valor justo \\
\hline Figura 35 & Resultado líquido, por holding categories, para bancos de menor porte \\
\hline Figura 36 & Resultado líquido, por holding categories, para bancos de médio porte \\
\hline Figura 37 & Resultado líquido, por holding categories, para o Banco Washington Mutual \\
\hline
\end{tabular}


Figura 38 Resultado líquido, por holding categories, para o Banco IndyMac

Figura 39 Resultado líquido, por holding categories, para o Downey Savings and Loan

Figura 40 Tópicos mencionados espontaneamente durante resposta à primeira questão

Figura 41 Relação equilibrada entre dois grupos de países

Figura 42 Relação não equilibrada entre dois grupos de países

Figura 43 Agrupamentos para apresentação da questão 2

Figura 44 Fatores mais relevantes para a deflagração da crise

Figura 45 Fatores de média relevância na deflagração da crise

Figura 46 Fatores menos relevantes na deflagração da crise

Figura 47 Fatores mais relevantes no agravamento da crise

Figura 48 Fatores de média relevância no agravamento da crise

Figura 49 Fatores menos relevantes no agravamento da crise

Figura 50 Significado de fair value accounting

Figura 51 Concordância com efeito pró-cíclico da contabilidade a valor justo

Concordância com proposição de que a crise seria descoberta mais tardiamente, sem contabilidade a

Figura 52 valor justo

Figura 53 Concordância com a proposição de que a contabilidade a valor justo agravou a crise

Concordância com a proposição de que sem o valor justo o efeito dos preços sobre a crise seria

Figura 54 semelhante 


\section{INTRODUÇÃO}

\subsection{Contexto}

Segundo Wolf (2009, p. 15), se todas as informações estiverem disponíveis no mercado, quem não investir em sua obtenção pode beneficiar-se dos esforços onerosos de quem gastou recursos para consegui-las. Esse fato reduzirá os incentivos para investir em informações, deixando os mercados mais sujeitos aos caprichos da "ignorância racional". Se os ignorantes seguirem as pessoas que consideram mais bem informadas, ocorrerá o "comportamento de manada". Finalmente, quando a incerteza é difusa e inevitável, as manadas poderão tanto inflar quanto estourar "bolhas".

Seguindo o raciocínio do parágrafo acima, pareceria óbvio entender que, quanto maior o nível de evidenciação de uma companhia, menor seria a assimetria de informações e, consequentemente, o que os economistas chamam de "efeito manada" seria reduzido. Por outro lado, o aumento de disclosure nem sempre é desejado pelas empresas, pois quando a evidenciação é privilegiada, corre-se o risco de abrir informações estratégicas.

$\mathrm{O}$ mundo caminha em direção à redução da assimetria de informações, acrescentando qualidade às informações contábeis, mas ainda assim está longe de produzir verdades absolutas.

Os anos de 2006 e 2007 confirmaram as expectativas de um grande salto qualitativo nas normas brasileiras de contabilidade. Isso porque, desde o início deste século, os principais acadêmicos e profissionais da área já vinham discutindo e negociando o Projeto de Lei 3.741, que tinha entre seus objetivos desvincular a evolução da contabilidade societária das amarrações tributárias e legais e colocar o Brasil no caminho das Normas Internacionais de Contabilidade. O Projeto de Lei culminou na publicação da Lei 11.638, em dezembro de 2007. Antes da publicação da Lei, o Banco Central do Brasil, a SUSEP e a CVM já haviam se pronunciado, com a publicação do Comunicado 14.259/06, da Circular 357/07 e da Instrução 457/07, respectivamente. Com a adoção das Normas Internacionais de Contabilidade do IASB International Accounting Standards Board - não só pelos bancos, mas pelas empresas nãofinanceiras, a partir do exercício findo em 31 de dezembro de 2010, a mensuração de ativos e passivos pelo seu valor justo será prática comum nas companhias brasileiras. Desta forma, torna- 
se fundamental o estudo e a disseminação do valor justo na contabilidade, assim como suas eventuais implicações em cenários onde são experimentadas grandes mudanças. Nesse contexto, o presente trabalho pretende contribuir, destacando os principais pontos de discussão acerca do assunto, com base em um referencial teórico ainda escasso no Brasil. A Figura 1, abaixo, ilustra a representatividade desse tipo de mensuração no total de ativos de 11 bancos que atuam nos Estados Unidos da América, onde o FASB - Financial Accounting Standards Board, órgão que emite pronunciamentos contábeis, em setembro de 2006 publicou a SFAS 157, norma de aplicação obrigatória para exercícios iniciados a partir de 15 de novembro de 2007, inclusive em demonstrações interinas, e serviu como base para a publicação de um Discussion Paper e do Exposure Draft do IASB sobre valor justo. Com uma amostra formada por 50 instituições, entre bancos, seguradoras, corretoras, instituições de crédito e empresas governamentais, a SEC (2008, p. 46) também buscou quantificar a relevância da mensuração pelo valor justo, como pode ser visto nas Figuras 2, 3 e 4, que mostram o percentual de ativos ao valor justo de uma forma geral, segregado por indústria e por tamanho, respectivamente.

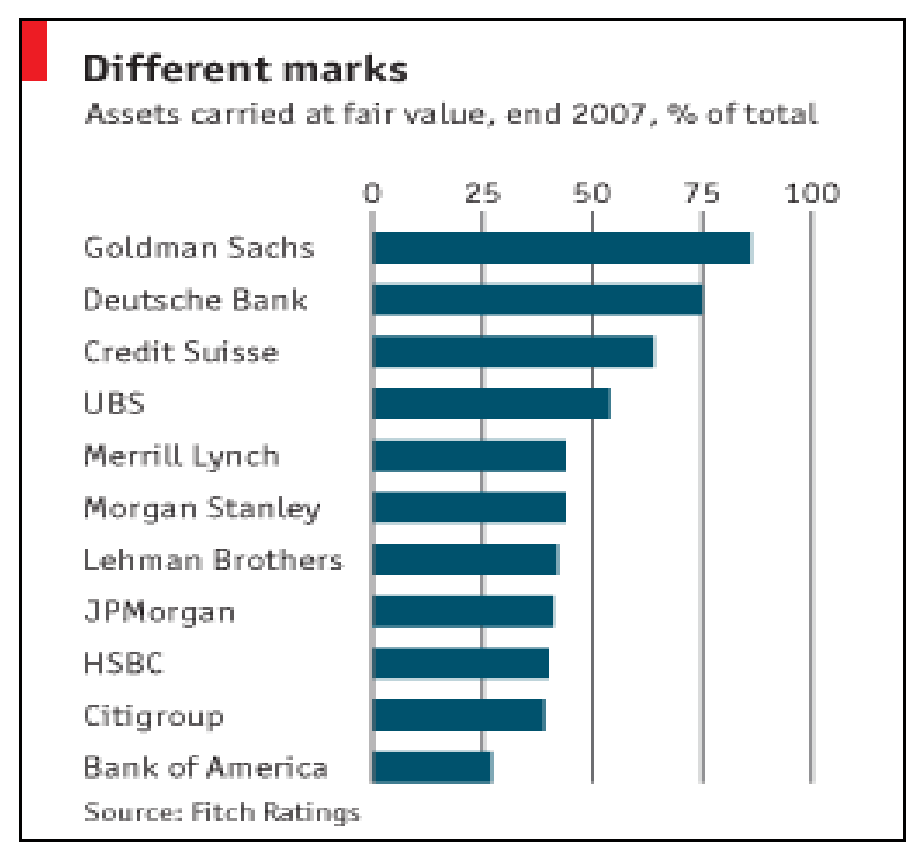

Figura 1: Proporção de ativos contabilizados pelo valor justo, ao final de 2007 - Fitch Rating

Fonte: http://www.economist.com/finance/displaystory.cfm?story_id=12274096

Ressalta-se que a SFAS 157 é um guia para a aplicação do valor justo, o qual foi desenvolvido pelo FASB para agregar em um único documento as definições, características e recomendações para a aplicação e evidenciação do valor justo, as quais estavam antes espalhadas 
em diversos outros pronunciamentos. Há cerca de dois anos, as duas principais instituições de pronunciamentos contábeis do mundo, FASB e IASB, redigiram um documento chamado Memorandum of Understanding, no qual acenaram para o mundo que as normas emitidas pelas duas instituições tendem a convergir para o mesmo sentido, criando um padrão internacional de contabilidade único. Com isso em pauta, o IASB reproduziu a ideia do FASB, redigindo um Discussion Paper, e posteriormente, um Exposure Draft, cujo objetivo é a criação de um guia único para a aplicação do valor justo, documento totalmente baseado na SFAS 157, com poucas, porém importantes, ressalvas e considerações. Estudo da SEC (2008, p. 58) mostra que a publicação da norma do FASB não impactou aumento significativo na mensuração de ativos ao valor justo, aparentemente porque o mercado, ao realizar uma mensuração pelo valor justo, já aplicava conceitos da SFAS 157. Os ativos mensurados ao valor justo, na amostra utilizada pela SEC, passaram de $42 \%$ do total, em 2006, para 45\% do total, no primeiro trimestre de 2008.
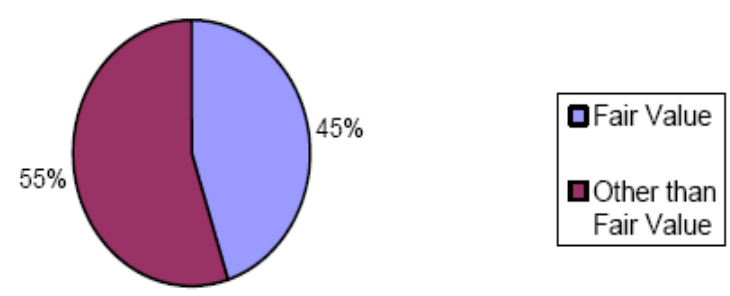

Figura 2: Proporção de ativos mensurados ao valor justo, ao final do primeiro trimestre de 2008 - SEC (2008, p. 46)

A definição de valor justo, segundo o Parágrafo 10 do Discussion Paper do IASB, se refere ao montante pelo qual um ativo poderia ser trocado ou um passivo liquidado entre partes interessadas, não relacionadas e com suficiente conhecimento sobre a transação ${ }^{l}$.

\footnotetext{
1 "The amount for which an asset could be exchanged, or a liability settled, between knowledgeable, willing parties in an arm's length transaction" (with some slight variations in wording in different standards).
} 


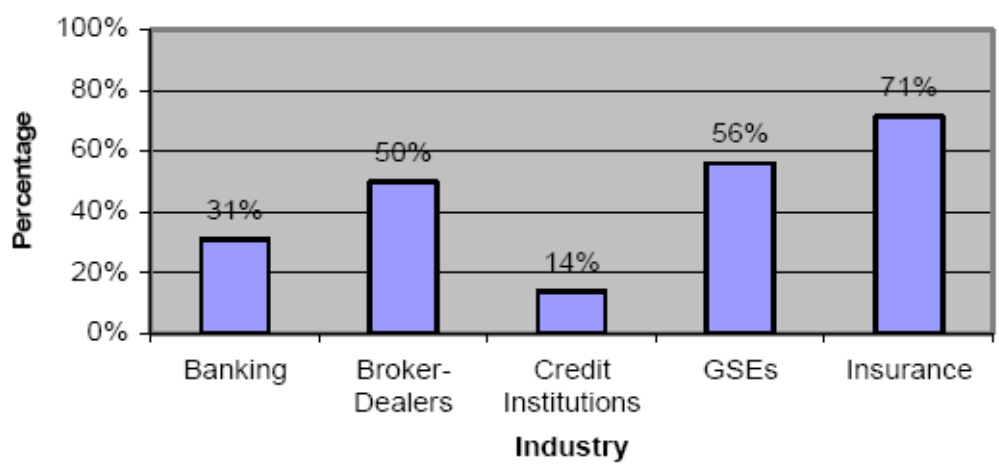

Figura 3: Proporção de ativos mensurados ao valor justo por indústria, ao final do primeiro trimestre de 2008 SEC (2008, p. 47)

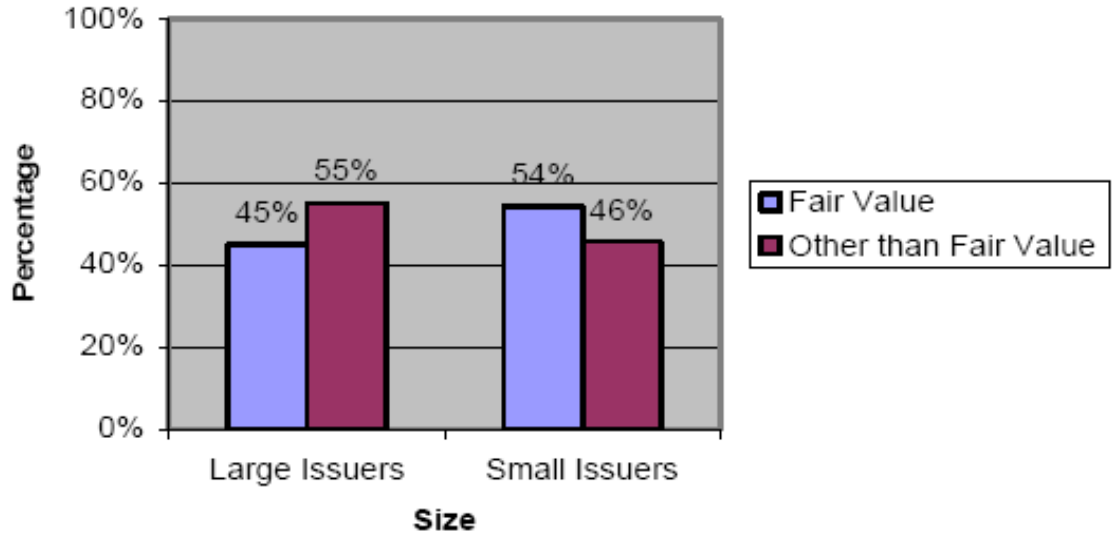

Figura 4: Proporção de ativos mensurados ao valor justo por tamanho, ao final do primeiro trimestre de 2008 SEC (2008, p. 48)

O entendimento completo dessa breve definição não é algo simples, pois a própria definição do discussion paper do IASB, quando confrontada com a definição da SFAS 157 ou de outros autores, demonstra divergências ou deixa abertura para ambiguidades e discussões. Outro ponto importante: $\mathrm{O}$ exposure draft publicado recentemente pelo IASB traz uma definição exatamente igual à do FASB, que é apresentada na nota 2 deste estudo.

No entanto, mesmo se a definição fosse completamente aceita e entendida, ainda assim a prática da mensuração pelo valor justo abriria questões como a que segue:

- Como definir o valor justo de um ativo ou passivo, se nem sempre existe um valor de mercado ou uma informação totalmente objetiva sobre o objeto a ser mensurado? 
Sobre este assunto, o FASB se posiciona apresentando uma hierarquia de mensuração. Segundo a SFAS 157, a hierarquia para a definição do valor justo dá a prioridade mais alta aos preços cotados em mercados dinâmicos para ativos e passivos idênticos, e a menor prioridade aos inputs que não são observáveis em um mercado.

A seguinte hierarquia é aplicada com o propósito de determinar o valor justo de um ativo ou passivo, segundo Mard [et al.] (2007, p. 7-8):

- Nível I: As entradas são observáveis e refletem preços cotados em um mercado ativo a que a entidade tem acesso na data de mensuração, para ativos ou passivos idênticos;

- Nível II: As entradas são observáveis, porém não refletem preços cotados em um mercado ativo a que a entidade tem acesso na data de mensuração, para ativos ou passivos idênticos. As entradas do nível II incluem os seguintes itens:

- Preços cotados em mercados ativos para ativos ou passivos similares;

- Preços cotados para ativos ou passivos idênticos ou similares em mercados que não são ativos, isto é, mercados onde existem poucas transações para o ativo ou passivo mensurado; os preços podem variar substancialmente, podem depender de market makers, ou ainda, onde poucas informações sobre o ativo ou passivo são divulgadas;

○ Informações de mercado que não sejam as cotações dos ativos ou passivos mensurados, tais como taxas de juros, curvas de juros, volatilidades ou taxas de inadimplência observáveis;

○ Informações de mercado que não são diretamente observáveis para o ativo ou passivo a ser mensurado, mas derivam principalmente de outros dados de mercado, estes sim observáveis. Por exemplo, por meio de extrapolação ou interpolação corroborada por outros dados de mercado observáveis.

- Nível III: As entradas não são dados observáveis de mercado. Por exemplo, entradas que derivam de extrapolação ou interpolação não corroboradas por dados observáveis. Entradas não-observáveis podem ser utilizadas quando inputs observáveis não estão disponíveis. Também são permitidas quando há pouca ou nenhuma atividade de mercado para o ativo ou passivo avaliado. No entanto, o objetivo da mensuração a valor justo permanece o mesmo, isto é, um valor de saída sob a perspectiva de um participante do mercado. 
Então, se o mercado não é líquido para certo ativo ou passivo, de acordo com os níveis II e III, uma Entidade determinaria o valor justo usando uma técnica de valuation, incluindo:

- Transações recentes com partes não relacionadas;

- Referência ao atual valor justo ou outro ativo financeiro substancialmente semelhante;

- Análise de fluxo de caixa descontado;

- Modelos de precificação de opções.

Muitas vezes, a utilização dessas técnicas envolve entradas e/ou critérios subjetivos. Foi nesse sentido que a SFAS 157 introduziu exigências adicionais de evidenciação, com o objetivo de tornar mais transparente o processo de mensuração ao valor justo.

A primeira grande crise econômica deste século, chamada inicialmente de crise americana ou crise do subprime, e posteriormente de crise bancária, crise de crédito, crise do sistema financeiro, crise de liquidez, crise financeira mundial e até crise global, foi deflagrada nos Estados Unidos da América após um longo período de euforia, supervalorização de imóveis e subavaliação de riscos. Muitos culpados já foram apontados, ou por terem servido de gatilho para o problema, ou por terem criado um ambiente propício, ou mesmo por terem agravado a situação. A contabilidade não escapou ilesa dessa discussão, e um dos principais vilões foi a chamada contabilidade a valor justo. Neste trabalho nos referiremos a este critério de mensuração ora pelo nome em inglês (fair value), ora em português (valor justo), pois apesar de haver uma tradução para o nosso idioma, o termo em inglês é utilizado largamente por diversos autores nacionais.

Desta forma, o presente trabalho pretende estudar o valor justo à luz do pensamento de especialistas em economia e mercado financeiro, verificando se, entre fatores que prepararam ou agravaram a crise, a contabilização pelo valor justo desempenhou papel decisivo.

\subsection{Problema de Pesquisa}

A primeira etapa a ser cumprida para alcançar os objetivos de uma investigação científica é o descobrimento do problema ou lacuna num conjunto de conhecimentos, segundo Lakatos e Marconi (2008, p. 84). 
No caso deste trabalho, o próprio estudo da contabilidade a valor justo já explora uma lacuna na literatura contábil. E quando se trata dos motivadores ou agravadores da crise financeira mundial, os acadêmicos da contabilidade têm a obrigação de olhar para o mercado e entender um complexo cenário que envolve globalização, mudanças no fluxo internacional de recursos, novos instrumentos financeiros, falhas de cunho regulatório, etc., para preparar sua resposta.

Assim, este trabalho procura responder à seguinte questão: Na visão de especialistas em economia e mercado financeiro, a contabilidade ao valor justo teve papel decisivo na deflagração ou agravamento da crise financeira mundial?

\subsection{Hipótese}

A hipótese de pesquisa é que a contabilização pelo valor justo, na visão de especialistas em economia e mercado financeiro, não contribuiu para a deflagração da crise, mas atuou como agravador da crise financeira mundial.

\subsection{Objetivos}

O objetivo geral deste trabalho é entender o papel da contabilidade ao valor justo na crise financeira mundial.

Para alcançar o objetivo geral, o trabalho mostra um panorama sobre a teoria do valor justo e seus principais pontos de discussão.

Como objetivo específico, o procedimento de pesquisa busca entender a opinião de especialistas em economia e mercado financeiro a respeito do tema.

Para entender a visão desses especialistas, o trabalho traz uma revisão de publicações recentes da área de economia, com o objetivo de elencar os principais fatores que desencadearam a crise, assim como aqueles que agravaram esta. 


\subsection{Justificativa}

Atualmente, o Brasil e diversos países do mundo se encontram em pleno processo de adoção das normas internacionais de contabilidade do IASB, nas quais o uso do valor justo como critério de mensuração é um dos tópicos mais controversos.

O valor justo como critério de mensuração já estava presente nas normas do FASB desde o início da década de 1990, e, muito antes das publicações de discussões desta década, também nos pronunciamentos do IASB sobre instrumentos financeiros. Nos Estados Unidos da América, em 2006, o FASB publicou a SFAS 157 para fazer o papel de guia de mensuração e divulgação, enquanto para o resto do mundo, o IASB prepara um pronunciamento, que, na data de conclusão desta pesquisa, estava em fase de Exposure Draft. A divulgação de informações sobre esse tipo de mensuração já era sugerida ou exigida por pronunciamentos específicos; no entanto, a publicação desses guias traz entre seus principais objetivos aumentar a transparência do processo de avaliação, o que se traduz na possibilidade de o usuário da informação contábil refazer um número quando não concordar com técnicas ou premissas adotadas.

A avaliação de ativos e passivos ao seu valor justo não é de fato assunto totalmente novo, mas, ao ser trazida para a realidade das empresas pelos dois principais órgãos de normatização contábil do mundo, foi colocada em evidência de forma nunca vista. Assim, surgiram cerca de uma dezena de livros nos Estados Unidos e na Europa e diversos papers sobre o assunto.

No Brasil, o assunto ainda foi pouco discutido. Até junho de 2009, não havia normas específicas sobre valor justo, apenas tentativas isoladas do Banco Central, da CVM e do CPC, que falavam em valor de mercado de instrumentos financeiros, com detalhamento bastante reduzido sobre o que se esperava desse tipo de mensuração e, principalmente, sobre premissas e técnicas de avaliação. Em junho de 2009, ainda não havia nenhum livro publicado no Brasil específico sobre o tema, e menos de uma dezena de artigos publicados.

O impacto da contabilização pelo valor justo foi estudado em iniciativa conjunta pelo IASB e pelo FASB, que esclareceram algumas práticas, face aos novos desafios que a crise trouxe para a discussão. Em primeira instância, estão sendo atendidas as recomendações do Financial Stability Forum (FSF). 


\subsection{Delimitação do Escopo}

Este trabalho faz uma análise dos Pronunciamentos do FASB e do IASB sobre valor justo, e na sequência busca um entendimento geral sobre a atual crise econômica. Ao buscar esse entendimento, o trabalho procura respostas para a questão de pesquisa.

Trata-se de um trabalho do Departamento de Contabilidade da FEA-USP; portanto, não é seu objetivo esmiuçar as teorias econômicas, embora delas faça uso.

Propositadamente, não foram selecionados contadores entre os profissionais entrevistados. Os contadores não foram considerados para evitar respostas enviesadas pelos conhecimentos da contabilidade tradicional ou da contabilidade internacional.

\subsection{Estrutura do Trabalho}

Este trabalho está estruturado da seguinte forma:

- Primeiro capítulo - contextualiza o objeto estudado, expõe os objetivos e a justificativa do projeto, delimita o escopo da pesquisa e enuncia sua estrutura.

- Segundo capítulo - revisão da literatura. Revisita o arcabouço teórico da mensuração de ativos e passivos na contabilidade e explora os principais aspectos da teoria do valor justo.

- Terceiro capítulo - análise da parte empírica relacionada ao assunto em estudo, seguindo os objetivos enunciados no capítulo 1 e buscando responder à questão de pesquisa.

- Quarto capítulo - conclusões.

- Referências bibliográficas. 


\section{REVISÃO BIBLIOGRÁFICA}

\subsection{MENSURAÇÃO DE ATIVOS E PASSIVOS}

A primeira parte deste trabalho trata de mensuração, assunto discutido historicamente tanto entre os economistas como entre os contadores.

Para Adam Smith (2003, p. 46), o trabalho é a única medida exata e universal de valor, o único padrão que permite comparar os valores de diferentes mercadorias em todos os tempos e em todos os lugares. Ricardo (2001, p. 35) evoluiu este conceito, alertando sobre flutuações nos preços do trabalho e de outros bens utilizados como moeda de troca, e também admitindo a influência do aperfeiçoamento da mão-de-obra e do capital empregados. Pouco mais de um século depois, o conceito econômico de valor evoluiu ainda mais, até chegar a Keynes (1982, p. 228), que ensina que a formação de preços geralmente é definida em função das condições de oferta e procura e das variações no custo marginal e da elasticidade da oferta. Em uma indústria específica, o nível de preços dependeria da remuneração dos fatores produtivos que fazem parte do custo marginal e, em parte, da escala de produção.

A moeda é o elemento que liga o presente ao futuro, sendo que a sua quantidade também impacta a formação de preços. Além da quantidade de moeda e dos elementos relacionados à oferta e à demanda, o volume de emprego e o nível de salários também são citados por Keynes (1982, p. 230) entre fatores que impactam a formação dos preços.

A Contabilidade, assumindo a função de relatar fatos econômicos, deve entender, acompanhar e, de maneira mais ambiciosa, antecipar a evolução desses conceitos.

Para chegar ao assunto valor justo, faz-se necessário entender antes o que é mensuração e quais são os principais critérios aceitos na ciência contábil.

Segundo Hendriksen e Van Breda (1999, p. 304), “em contabilidade, mensuração é o processo de atribuição de valores monetários significativos a objetos ou eventos associados a uma empresa, e obtidos de modo a permitir agregação (tal como na avaliação total de ativos) ou desagregação, quando exigida em situações específicas”.

Da discussão iniciada no Parágrafo 16 do Discussion Paper do IASB, conclui-se que a melhor expressão do valor econômico no ato de uma transação é o próprio preço acordado entre o 
comprador e o vendedor. Essa afirmação decorre do Princípio do custo como base de valor. Não só no ato da transação, mas principalmente em momentos posteriores, a discussão sobre bases de mensuração é uma das principais no mundo da contabilidade. Iudícibus (2006, p. 63) lembra que algumas considerações mais recentes, como o Statement of Financial Accounting Standard SFAS 133, inovaram violentamente, deixando para trás o entendimento original do custo como base de valor. A representação dos ativos deve ser verdadeira e justa (true and fair), o que leva ao esforço de avaliação aos valores de mercado, sendo que, quando esses não existem objetivamente para o ativo que está sendo avaliado, deverão ser calculados subjetivamente através de fórmulas que levem em conta os fluxos de caixa gerados pelos ativos, as taxas de desconto apropriadas e o horizonte de geração dos fluxos.

Os critérios de mensuração são divididos neste trabalho em valores de saída e valores de entrada, tendo como base as considerações de Martins (2001, p. 94 - 121), Hendriksen e Van Breda (1999, p. 303 - 313) e Iudícibus (2006, p. 140 - 152).

Martins (2001, p. 25) lembra que o conflito entre a utilidade, a praticabilidade e a objetividade faz parte do cotidiano do gestor do sistema de informações. Segundo o mesmo autor, os valores de entrada são aqueles obtidos nos segmentos de mercado de compra da entidade e refletem a importância associada à obtenção dos recursos, enquanto os valores de saída, obtidos nos segmentos de venda, refletem a importância dada pelo mercado aos recursos de que a empresa dispõe.

\subsubsection{Valores de saída}

Os valores de saída buscam aproximar a informação referente ao item avaliado ao seu valor econômico. Por isso, costumam levar vantagem no quesito "relevância". No entanto, encontrar um valor de saída adequado nem sempre é uma tarefa simples na prática, o que faz com que a informação seja mais subjetiva.

Outra crítica frequentemente atribuída aos valores de saída é que, em geral, esses critérios permitem o reconhecimento de receitas ainda não realizadas, ou seja, o potencial ganho da entidade sobre determinado ativo é reconhecido antes da transferência desse ativo para uma terceira parte. 
- Valor presente dos fluxos de caixa futuros

Também conhecido por Valor Presente Líquido, ou VPL, o método se baseia em um fluxo de caixa descontado, fluxo este que considera todas as despesas e receitas referentes ao ativo ou passivo principal. O VPL deve ser utilizado somente quando os fluxos de caixa futuros podem ser estimados com razoável segurança. Além disso, deve ser aplicado em ativos ou passivos que se realizarão em longo prazo, ou em prazo indiferente quando resultar em efeito relevante.

As principais críticas ao VPL são direcionadas à busca de uma taxa de desconto apropriada para trazer um fluxo a valor presente.

O valor presente dos fluxos de caixa futuros pode ser calculado de forma simples, agrupando fluxos positivos e negativos em períodos, conforme a fórmula a seguir:

- $\mathrm{FlCx}_{0}$ : Agrupamento das entradas e saídas do período 0, ou seja, fluxos positivos e negativos que ocorrem imediatamente, a vista;

- $\mathrm{FlCx}_{1}$ : Agrupamento das entradas e saídas do período 1, ou seja, fluxos positivos e negativos que ocorrem ao final do primeiro período;

- $\mathrm{FlCx}_{2}$ : Agrupamento das entradas e saídas do período 2, ou seja, fluxos positivos e negativos que ocorrem ao final do segundo período;

- $\mathrm{FlCx}_{\mathrm{n}}$ : Agrupamento das entradas e saídas do período n, ou seja, fluxos positivos e negativos que ocorrem ao final do n-ésimo período;

$$
V P L=\frac{F l C x_{0}}{(1+i)^{0}}+\frac{F l C x_{1}}{(1+i)^{1}}+\frac{F l C x_{2}}{(1+i)^{2}}+\ldots+\frac{F l C x_{n}}{(1+i)^{n}}
$$

- n é o número de períodos considerados no cálculo;

- i é a taxa de juros utilizada para descontar os fluxos a valor presente. 


\section{- Preços correntes de venda}

Trata-se de um valor de mercado de saída, ou seja, o valor que se espera obter com a venda de um ativo ou liquidação de um passivo, em uma transação sem favorecimento. Em um mercado ativo, o preço corrente de venda tende a ser uma aproximação bastante adequada para o valor que seria recebido em caixa ou equivalentes com a realização de um ativo.

Quando não se espera vender um ativo em um curto prazo, seu preço atual deveria ser descontado ao valor presente. Custos e despesas adicionais também deveriam ser considerados. Uma vantagem importante deste método é aproximar o valor contábil do valor econômico. Por outro lado, a objetividade dos valores de venda muitas vezes é prejudicada na prática de sua obtenção.

\section{- Valor realizável líquido}

Contém as principais características do método anterior, e pode ser entendido como um preço corrente de venda deduzido dos gastos necessários para a realização do item avaliado. O valor realizável líquido é amplamente utilizado nos testes de impairment, que verificam se o valor contábil de um ativo é superior ao seu valor de realização, e buscam reduzir o valor contabilizado a este valor de realização.

\section{- Valores de liquidação}

Ao contrário dos métodos anteriores, que trabalham em situações normais, os valores de liquidação servem para uma hipótese de descontinuidade, quando existe urgência na venda dos ativos e/ou na liquidação dos passivos. É presumida uma venda forçada. A utilização deste método não é recorrente e é aplicada quando existe a descontinuidade total ou parcial de um empreendimento. 


\subsubsection{Valores de entrada}

Como muitas vezes não existe um valor de mercado para valores de venda, os valores de entrada são comumente considerados mais adequados como base da avaliação de ativos. Também são considerados mais objetivos.

A despeito do que foi descrito no parágrafo acima, os critérios baseados em valores de entrada tendem a distanciar o resultado contábil do resultado econômico, à medida que não reconhecem os ganhos potenciais do item avaliado, reconhecendo somente as receitas e despesas efetivamente "realizadas".

\section{- Custo histórico}

É o método mais tradicional, amplamente utilizado por ser objetivo, verificável e simples. O custo histórico corresponde ao valor de troca somente no momento em que um ativo é adquirido. As principais críticas ao método residem justamente no fato de que, em momentos posteriores, o valor de troca não é representado. O método não permite a separação entre o ganho nas operações e os ganhos decorrentes de aquisições fortuitas ou variações imprevistas de preços. Em defesa do custo histórico, a contabilidade tradicional possuía o "Princípio do registro pelo valor original", também conhecido como "custo como base de valor", enunciado pelo CRC SP (1999, p. 22) conforme segue: "Os componentes do patrimônio devem ser registrados pelos valores originais das transações com o mundo exterior, expressos a valor presente na moeda do País, que serão mantidos na avaliação das variações patrimoniais posteriores, inclusive quando configurarem agregações ou decomposições no interior da ENTIDADE”.

\section{- Custos correntes}

São valores de mercado, de compra. O método oferece a possibilidade de distinguir o lucro decorrente da transação dos ganhos ou perdas resultantes da posse de ativos antes de sua utilização. 
Segundo Hendriksen (1999, p. 235) o método permite predição superior dos resultados da empresa. Os custos podem ser substancialmente diferentes dos preços correntes, principalmente quando são avaliados estoques e imobilizados.

\section{- Custos históricos corrigidos}

Trata-se do mesmo conceito do custo histórico. No entanto, com a vantagem de refletir a correção decorrente de aumentos ou diminuições do valor da unidade monetária. Esse critério é compatível com o Princípio do Registro pelo Valor Original, segundo CRC SP (1999, p. 23), tendo como pilar o "Princípio da Atualização Monetária”, o qual é enunciado conforme segue: "Os efeitos da alteração do poder aquisitivo da moeda nacional devem ser reconhecidos nos registros contábeis através do ajustamento da expressão formal dos valores dos componentes patrimoniais".

\section{- Custos correntes corrigidos}

Aproveitam-se das vantagens dos métodos de custos correntes e custos corrigidos. Assim, um custo de reposição obtido em $t_{0}$ pode ser comparado com um custo de reposição de $\mathrm{t}_{1}$, evidenciando a variação monetária entre os períodos.

O custo histórico evoluiu para o custo histórico corrigido, depois para o custo corrente, seguindo para o custo corrente corrigido para, finalmente, chegar ao valor justo e verdadeiro, seu valor econômico. Em relação às exigibilidades, Iudícibus (2006, p. 160) declara que "o valor de balanço deveria ser determinado pelo valor presente dos montantes a serem pagos no futuro."

Iudícibus (2006, p. 154) também diz que os valores de entrada são entendidos sempre sob uma premissa de continuidade, enquanto os valores de saída são entendidos, principalmente, sob uma premissa de descontinuidade, embora também possam ser entendidos sob premissa de continuidade.

A contabilidade tradicional não se preocupou em mostrar o verdadeiro valor, mas guardou a preocupação com a objetividade das avaliações. Nesse contexto, percebe-se que a mensuração 
ao valor justo caminha na direção da subjetividade, ao mesmo tempo em que tenta se aproximar do valor econômico.

\subsection{VALOR JUSTO}

\subsubsection{Conceitos e definições}

Em uma tradução livre, o parágrafo 5 da SFAS 157 define valor justo como o valor que seria recebido ao vender um ativo ou pago ao transferir um passivo em uma transação corriqueira entre participantes do mercado na data de mensuração ${ }^{2}$. Em 1990, ao receber as cartascomentário do Exposure Draft da SFAS 107, o FASB percebeu que o termo market value, amplamente usado no pronunciamento, causava confusão, fazendo com que muitos leitores entendessem que o tal valor de mercado era um valor próprio do mercado secundário. Assim, conforme a SFAS 107 (1991, p. 16), o termo market value foi substituído por fair value, para evitar a confusão mencionada e também para manter uniformidade com pronunciamentos contábeis americanos e internacionais emitidos por outras entidades.

Como a tradução literal não revela totalmente a ideia por trás da definição de valor justo, Iudícibus e Martins (2007, p. 3) trazem uma definição alternativa: "Valor justo é o montante pelo qual um determinado item poderia ser transacionado entre participantes dispostos e conhecedores do assunto, numa transação sem favorecimento".

A definição da SFAS 157 difere das definições das encontradas nas atuais IFRS em três importantes pontos, os quais serão estudados nos próximos tópicos:

a. A definição da SFAS 157 fala explicitamente em valor de saída (selling price), enquanto as definições das IFRS não explicitam se o valor justo deve ser um valor de saída ou de entrada (buying price).

b. A definição da SFAS 157 se refere explicitamente a participantes de mercado, enquanto as IFRS falam de partes interessadas, não relacionadas e com suficiente conhecimento.

\footnotetext{
${ }^{2}$ Fair value is the price that would be received to sell an asset or paid to transfer a liability in an orderly transaction between market participants at the measurement date.
} 
c. Em relação aos passivos, a definição da SFAS 157 repousa sobre a noção de transferência dos passivos, onde entendemos que o passivo continua com a contraparte da transação, não sendo liquidado. A definição nas IFRS se refere ao montante pelo qual um passivo poderia ser liquidado entre partes interessadas, não relacionadas e com suficiente conhecimento.

Para Araujo (2003, p. 1), a moderna gestão de empresas descarta a postura convencional da busca pela medição de lucro e rentabilidade e cede espaço a uma gestão voltada à geração de riqueza dos acionistas. Segundo a autora, o objetivo da contabilidade é atuar como instrumento de administração, suportando o planejamento da entidade, identificando e determinando objetivos, analisando alternativas e efetuando projeções. Acompanha ainda o processo de execução de tomada de decisões. Como consequência desse cenário, situado em uma estrutura denominada Gestão Baseada em Valor ${ }^{3}$, alguns usuários da informação contábil demandam modelos que elucidem a criação ou não de riqueza pela entidade. A contabilidade tradicional, baseada no custo histórico, não atende em sua plenitude à gestão baseada em valor; por isso, são incorporados à contabilidade diversos conceitos provenientes da teoria de finanças.

Em oposição ao uso do valor justo na contabilidade, Sá $(2008$, p. 1) diz que "a questão não está em conservar valores históricos, mas, sim, em saber como de forma objetiva atualizálos. A questão não está em volatilidade, mas, em responsabilidade técnica e social. Se a informação contábil fica ao sabor do subjetivismo tem toda a condição de lesar a quem dela se utiliza”. Com opinião distinta, Lopes (2008) afirma que não existe uma discussão sobre o uso do fair value na avaliação de instrumentos financeiros, e reforça: "O fair value é o único meio para a avaliação de derivativos, já que a maioria desses instrumentos não tem um valor de custo. Abandonar o fair value seria como retornar à década de 1980, quando esses instrumentos ainda eram off-balance".

\footnotetext{
${ }^{3}$ VBM - Value Based Management
} 


\subsubsection{Valores de Saída}

\section{- segundo o FASB:}

O objetivo da mensuração por valor justo é determinar o valor que seria recebido na venda de um ativo ou pago pela transferência de um passivo na data da mensuração, isto é, um valor de saída. Esta definição incorpora expectativas presentes sobre fluxos de entrada futuros associados com o ativo e fluxos de saída associados com o passivo, sob a perspectiva dos participantes do mercado.

O parágrafo 25 do Concepts Statement 6 define ativos em termos de benefícios econômicos futuros (fluxos de entrada futuros), enquanto o parágrafo 35 do mesmo Concepts Statement 6 define passivos em termos de sacrifícios de benefícios econômicos (fluxos de saída futuros).

\section{- segundo o IASB:}

O parágrafo 49 do Framework for the Preparation and Presentation of Financial Statements do IASB da mesma forma define ativos e passivos em termos de entradas e saídas de benefícios econômicos. De acordo com o Parágrafo 13 do Discussion Paper do IASB, a maioria dos membros do IASB acredita que o valor justo como um preço de saída é coerente com as definições de ativos e passivos, além de ser mais apropriado, por refletir expectativas correntes do mercado sobre fluxos de entrada ou saída. Outros membros do IASB concordam com esta visão, mas não deixam de acreditar que os preços de entrada também refletem expectativas correntes do mercado sobre fluxos de caixa futuros. Desta forma, eles sugerem que o termo valor justo seja substituído por algum termo que descreva melhor esse tipo de mensuração, como preços correntes de entrada ou preços correntes de saída.

\section{- working papers:}

Conforme Barth e Landsman (1995), os conceitos de valor de entrada, valor de saída e valor em uso têm uma longa história na literatura contábil. Beaver e Demski (1979) deixam claro que é a ausência de mercados perfeitos e completos que faz com que esses conceitos resultem em valores diferentes. Assim, cada um deles pode prover uma informação diferente a respeito do valor de um ativo. Na data de aquisição, o valor em uso será nada menos que um valor de entrada, supondo a compra do ativo de forma racional. Em contraste, um valor de saída pode ser 
mais ou menos importante que um valor em uso, ou valor de entrada, pois ele é estabelecido por terceiros. Claramente, o valor em uso de um ativo pode ser diferente em cada firma.

Em consonância com os autores supracitados, conclui-se que os valores de saída são bastante adequados na mensuração de ativos e passivos destinados à negociação. No entanto, para ativos em uso, é possível que um valor de entrada represente melhor sua realidade econômica.

As diferenças entre valor em uso e valores de entrada e saída são medidas de capacidade gerencial. De acordo com a definição do FASB sobre o valor justo, que foca nos valores de saída, pode-se definir o valor da capacidade gerencial como a diferença entre valor em uso e valor de saída.

Segundo Barth e Landsman (1995), como o valor em uso é a única medida que sempre captura o valor total da firma associado a um ativo, é esse o valor que deveria ser considerado para a mensuração do valor justo.

\subsubsection{Participantes do mercado}

O Parágrafo 18 do Discussion Paper do IASB levanta a discussão que é colocada nesse trecho.

A SFAS 157 enfatiza que o valor justo é uma mensuração baseada no mercado, e não em atributos específicos de uma entidade. Assim, a definição exige que fiquem claras as principais características dos participantes de mercado referidas na SFAS 157:

- Não são partes relacionadas;

- Têm conhecimento suficiente da transação e do mercado, possuindo todas as informações relevantes, incluindo a obtenção de informações através de diligências usuais e costumeiras;

- Estão habilitados a transacionar o ativo ou passivo;

- Têm interesse na transação, ou seja, estão motivados, mas não compelidos a negociar.

Segundo o IASB, o comprador ou o vendedor está interessado, mas não compelido a negociar. Ele efetivará a negociação somente por valores de mercado, pois tem razoável conhecimento do mercado e outras oportunidades para negociar. A definição também se refere a partes não relacionadas, ou seja, a contraparte age com interesses totalmente independentes da 
entidade principal, o que visa garantir que o preço não foi arbitrado para atender interesses específicos de qualquer uma das partes.

De acordo com Keynes (1982, p. 247), é próprio da natureza dos mercados financeiros organizados, sob a influência de compradores, em sua maioria ignorantes do que compram, e de especuladores que estão mais interessados nas previsões da próxima mudança de opinião do mercado do que em uma estimativa racional dos futuros rendimentos dos bens de capital, que as cotações desçam em um movimento súbito e catastrófico quando uma decepção atinge mercados otimistas e superabastecidos. Keynes tem o apoio de outros economistas, como Galbraith (2007, p. 265-270), que escreveram sobre especulação e mercados em euforia, o que poderia comprometer a premissa de que os participantes do mercado deveriam ter "conhecimento suficiente da transação e do mercado". Por este motivo, pronunciamentos recentes do FASB e do IASB se preocupam mais com a mensuração do valor justo em mercados ilíquidos ou estressados.

\subsubsection{Transferência versus liquidação de um passivo}

A definição do FASB fala na transferência de passivos, enquanto o discussion paper do IASB falava em liquidação de passivos. Apesar de, em sua definição, o IASB falar em valor de liquidação, de acordo com Ernst\&Young (2007, p. 6) ele já admitia que o valor justo seria mais bem representado pela transferência de um passivo, pois pressupunha a existência de cotação em um mercado ativo ou um modelo de precificação que representasse valores de mercado, em vez de uma visão específica de cada entidade, quando se fala em valores de liquidação. Esta preferência foi confirmada com a publicação do exposure draft do IASB (2009, p. 13).

\subsubsection{Valor da transação e valor do reconhecimento inicial}

A IAS 39, em seu Parágrafo AG 76, diz que a melhor evidência do valor justo no reconhecimento inicial de um instrumento financeiro é o próprio valor da transação, exceto quando o valor justo do instrumento é evidenciado pela comparação com transações correntes 
observáveis do mesmo instrumento no mercado, ou baseado em técnicas de valuation em que são incluídas apenas variáveis de mercado observáveis.

O parágrafo 16 da SFAS 157, no entanto, menciona que preços de entrada e de saída são conceitualmente diferentes. A SFAS 157 alterou as regras das USGAAP para o reconhecimento inicial, permitindo o surgimento de ganhos ou perdas provenientes de valor justo diferente do valor de transação. Em certas situações, mesmo quando utilizada uma técnica de avaliação nível 3 (não observável), o reconhecimento de perdas ou ganhos no primeiro dia é permitido. Esta prática está em acordo com a decisão de mensurar o valor justo com base em preços de saída, em vez de preços de entrada.

Em resumo, hoje o FASB considera que, mesmo no primeiro reconhecimento, o valor da transação, por ser um valor de entrada, não poderia ser utilizado como evidência do valor justo, ao contrário do IASB, que possui pronunciamentos mencionando que o valor da transação é a melhor evidência do valor justo no reconhecimento inicial.

Se as definições da SFAS 157 forem incorporadas pelas IFRS sem futuras modificações nas presentes normas, algumas inconsistências serão geradas no conjunto das normas. Um conflito, por exemplo, surgiria do fato do valor da transação ser um valor de entrada.

O custo-benefício de avaliar um ativo ou passivo ao valor justo na data do seu reconhecimento inicial pode não compensar esse esforço, mesmo que, conceitualmente, pareça a decisão mais adequada. Por isso, exceto quando houver evidências de que o valor da transação seja significativamente divergente do seu valor justo, algum esforço nesse sentido valerá a pena.

O exposure draft do IASB (2009, p. 22-23) diferencia preços de entrada e preços de saída; enfatiza que o valor justo é um preço de saída, porém, continua reconhecendo que o valor da transação, no reconhecimento inicial, é a melhor evidência do valor justo, com algumas exceções listadas no documento.

\subsubsection{Mercado principal (ou mais vantajoso)}

O parágrafo 8 da SFAS 157 diz que o mercado mais vantajoso é aquele onde a entidade reportada venderia seu ativo ou transferiria seu passivo pelo preço que maximizaria o montante 
recebido pelos ativos ou minimizaria o montante pago na transferência dos passivos, considerando os custos de transação dos respectivos mercados.

O FASB concluiu que uma mensuração por valor justo deveria representar o preço no mercado principal (se observável, ou determinado por meio de técnicas de valuation), mesmo se o preço em um mercado diferente estiver potencialmente mais vantajoso na data de mensuração.

Desta forma, é possível perceber que o FASB procura preservar o Princípio da Consistência, ou seja, o mercado principal deve ser o mercado onde o ativo ou passivo é mais negociado, não devendo ser definido arbitrariamente, com o objetivo de gerenciar os valores contábeis da entidade.

Já o exposure draft do IASB (2009, p. 16), enuncia que, na ausência de evidências contrárias, uma entidade pode assumir que o mercado principal é o mercado mais vantajoso que ela pode ter acesso para determinado ativo ou passivo. O mercado principal é aquele com maior volume e nível de atividade para o ativo ou passivo.

\subsubsection{Atributos específicos}

O parágrafo 6 da SFAS 157 diz que uma medida de valor justo deveria considerar atributos específicos do ativo ou passivo; por exemplo, a condição e/ou localização do ativo ou passivo e restrições, se houver alguma, sobre a venda ou uso do ativo na data de medição. O IASB tem visão semelhante à do FASB.

Esta definição caminha na direção da subjetividade, porém, é consistente com uma visão estratégica, que pode ser diferente em cada entidade. Significa que um mesmo ativo pode produzir benefícios maiores ou menores, dependendo da estratégia de cada entidade.

Além da questão estratégica, as condições ou a localização de um ativo podem determinar que ele seja útil para uma entidade, mas não traga benefícios semelhantes para outra. 


\subsubsection{Valorização de passivos}

A SFAS 157 requer que a entidade considere os efeitos do risco de crédito no valor justo de um passivo. A IAS 39, em seu parágrafo AG69, declara que o valor justo deve refletir a qualidade de crédito do instrumento, e não o risco de crédito da própria entidade, como na SFAS 157.

Segundo Barth e Landsman (1995), embora conceitualmente a valorização de passivos seja feita da mesma forma que a valorização de ativos, ela é problemática para algumas firmas com condições financeiras em situação de deterioração, onde os valores dos passivos geralmente declinam.

Atualmente, algumas instituições financeiras avaliam instrumentos financeiros, como derivativos, por exemplo, pelo valor que eles poderiam ser totalmente protegidos (através de instrumentos de hedge), em vez de liquidados.

A avaliação de um passivo emitido pela própria entidade ao seu valor justo é justificável quando a entidade pretende recomprar o passivo em um prazo curto. No entanto, conforme ilustra a Figura 5, apenas uma minoria dos passivos é mensurada pelo valor justo. Na amostra analisada pela SEC ao final do primeiro trimestre de 2008, apenas 15\% dos passivos são mensurados pelo valor justo.

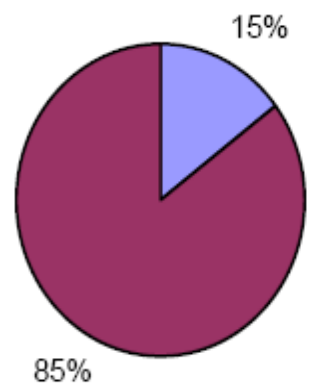


Fato interessante pode ser notado na Figura 6, que mostra que esses passivos mensurados ao valor justo estão concentrados nas companhias de grande porte, que costumam trabalhar com instrumentos financeiros de maior complexidade, segundo o estudo da SEC.

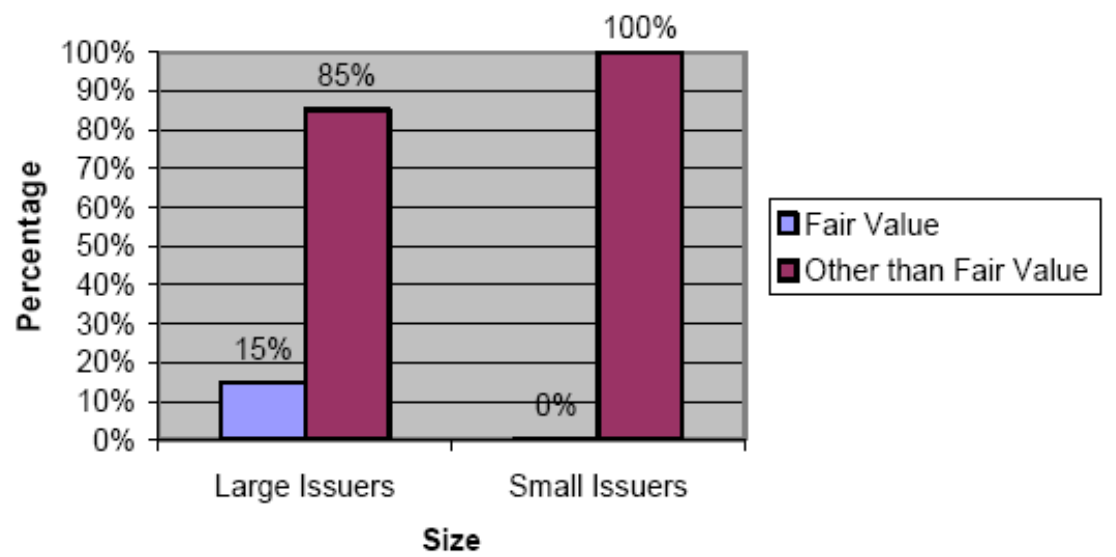

Figura 6: Percentual de passivos mensurados ao valor justo por tamanho da entidade - SEC (2008, p. 67)

\subsubsection{Entradas para técnicas de valuation}

De acordo com o Parágrafo AG 82 do Discussion Paper do IASB, as entradas para técnicas de avaliação podem ser observáveis ou não observáveis, conforme se expõe abaixo:

- Entradas observáveis são entradas que assumem que os participantes do mercado usariam na precificação dos ativos ou passivos, informações desenvolvidas com base em dados do mercado, obtidos de fontes independentes da entidade reportada. Preferencialmente, devem ser utilizadas entradas observáveis na mensuração de ativos e passivos, pois além de serem mais facilmente aceitas pelos auditores, oferecem maior possibilidade de reconstrução da informação reportada.

- Entradas não observáveis são entradas que refletem as próprias assunções da entidade reportada, que assume que os participantes do mercado precificariam ativos e passivos com base na melhor informação disponível na circunstância.

A SFAS 157 normatizou os diferentes tipos de entradas, dividindo-os em 3 níveis, conforme uma hierarquia, item abordado no próximo tópico. 


\subsubsection{Hierarquia do valor justo}

Técnicas de valuation devem ser selecionadas de forma que utilizem ao máximo os inputs do mercado, incluindo as expectativas do mesmo e medidas de fatores risco-retorno do ativo, utilizando o mínimo possível de inputs específicos da entidade.

Conforme mencionado na seção de contextualização deste trabalho, para aumentar a consistência e a comparabilidade da mensuração a valor justo e divulgações relacionadas, o FASB criou três grandes níveis de entradas para técnicas de valuation.

A prioridade mais alta é dada para preços cotados em mercados ativos para ativos e passivos idênticos aos avaliados pela entidade (Nível 1) e prioridade mais baixa às entradas não observáveis (Nível 3). A Figura 7, abaixo, ilustra os 3 níveis existentes na hierarquia do valor justo, mostrando no topo da pirâmide que no Nível 1 são utilizadas entradas observáveis, ou seja, sempre que a informação estiver disponível, e assim por diante.

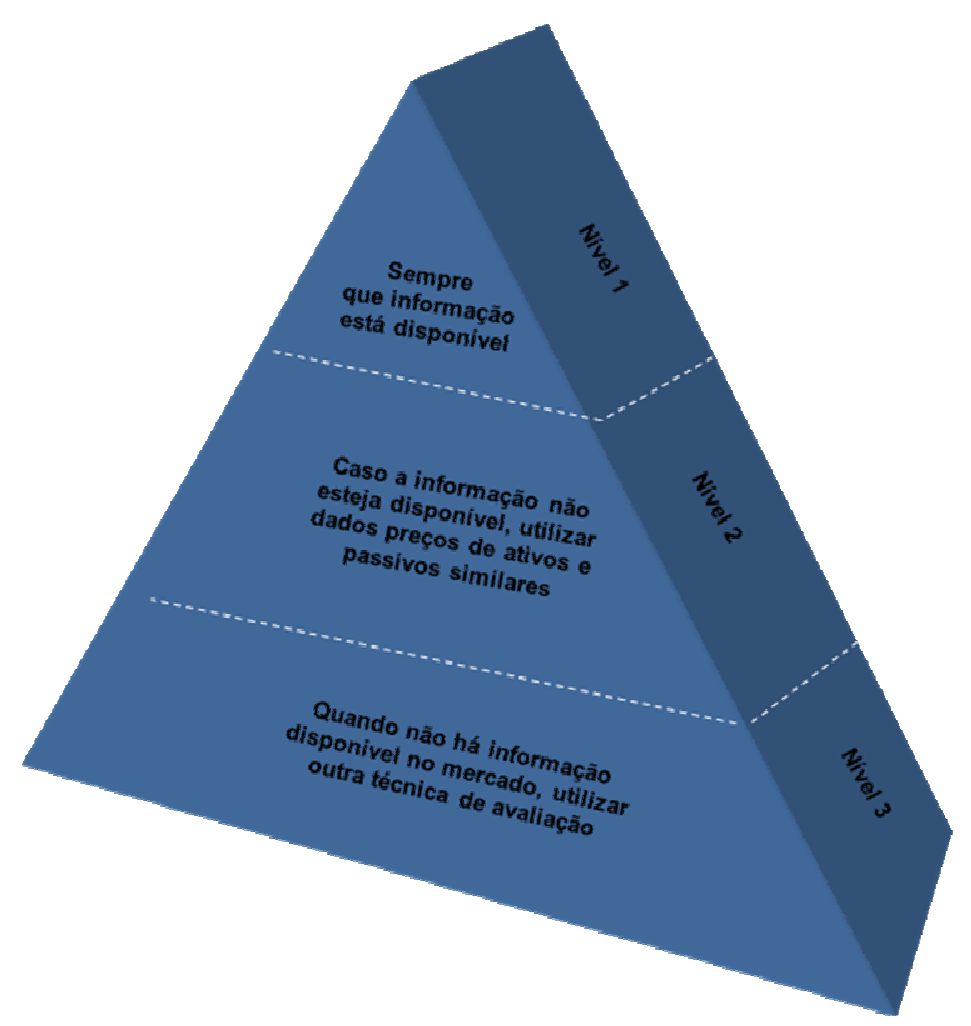

Figura 7: Hierarquia Fair Value - Fonte: Ernst \& Young (2005, p.3)

Em alguns casos, as entradas para avaliar um ativo ou passivo podem ser de diferentes níveis da hierarquia, porém, segundo a SFAS 157, deve-se pensar em considerar, para fins de 
divulgação, o nível de mais baixo de entrada (menos observável), desde que tenha impacto significativo sobre a avaliação do item como um todo.

A disponibilidade de entradas relevantes, assim como a confiabilidade dessas entradas, impacta diretamente a escolha de uma técnica de valuation adequada. No entanto, a hierarquia do valor justo prioriza as entradas, e não as técnicas. Por exemplo, uma medida de valor justo usando a técnica de Valor Presente pode ser considerada como Nível 2 ou Nível 3, dependendo das entradas relevantes que forem utilizadas para compor a mensuração.

Young (2008, p. 4) lembra que, com o desaparecimento dos mercados ativos de alguns instrumentos financeiros na crise do subprime, ativos que eram elegíveis para uma mensuração sob o Nível 1 frequentemente não possuíam mercados ou produtos suficientemente análogos para serem mensurados sob o Nível 2, o que fez com que fossem mensurados sob o Nível 3 da hierarquia do valor justo. O problema é que não haviam modelos estabelecidos para esse tipo de mensuração, que demandava expectativas sobre informações imponderáveis, como preços futuros dos imóveis, taxas de juros futuras e como os mutuários reagiriam sob as novas condições de mercado.

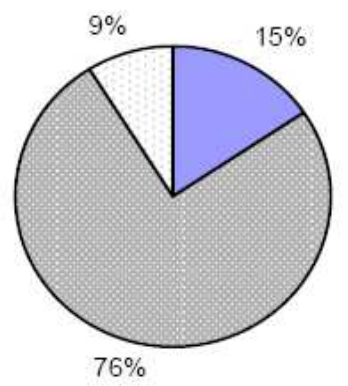

Figura 8: Classificação de ativos mensurados ao valor justo, de acordo com a hierarquia do valor justo, ao final do primeiro trimestre de 2008 - SEC (2008, p. 60) 


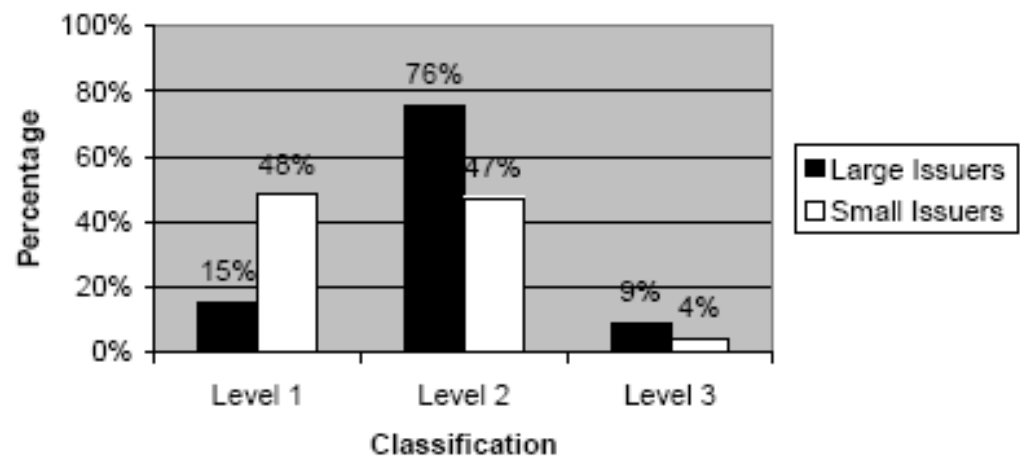

Figura 9: Classificação de ativos ao valor justo, de acordo com a hierarquia do valor justo - SEC (2008, p. 60)

A Figura 9, acima, mostra que a divisão desses percentuais pode variar entre companhias de grande e pequeno porte. A Figura 10 mostra que, para os passivos financeiros, a distribuição dos itens mensurados ao valor justo, de acordo com a hierarquia, é semelhante à distribuição dos ativos, que foi mostrada na Figura 8.
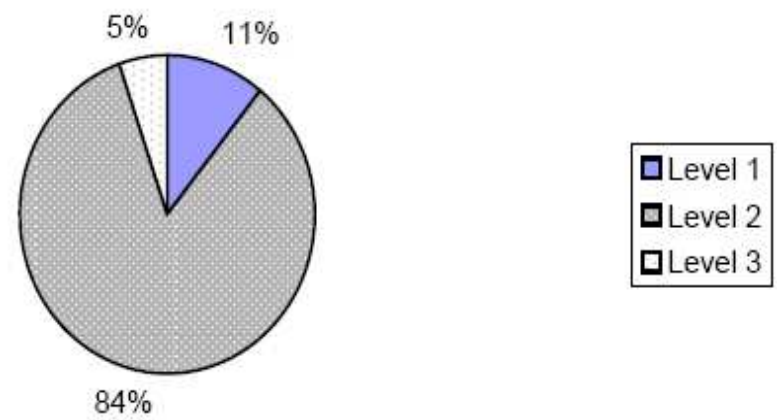

Figura 10: Classificação de passivos mensurados ao valor justo, de acordo com a hierarquia do valor justo, ao final do primeiro trimestre de 2008 - SEC (2008, p. 60)

Objetivando aumento de consistência e comparabilidade, o exposure draft do IASB (2009, p. 25-28) também adota esta hierarquia, baseada em 3 níveis de entradas.

\subsubsection{Valor em uso versus valor de troca}

O parágrafo 12 da SFAS 157 declara que uma mensuração ao valor justo supõe o melhor uso do ativo pelos participantes de mercado, considerando que o uso do ativo é possível, legalmente permitido, e financeiramente viável na data de mensuração. 
Com relação ao uso do ativo, são considerados dois diferentes tipos de premissa:

- Valor em uso. Pressupõe o uso combinado com outros ativos; por isso, mostra-se mais apropriada a certos ativos não-financeiros.

- Valor de troca (in-exchange). Pressupõe a venda do ativo isoladamente, para a aquisição de outros ativos. Bastante apropriada para ativos financeiros.

Pela natureza dos instrumentos financeiros, é provável que a maior parte desses ativos seja avaliada sob a premissa in-exchange (permuta), a qual considera os ativos sob uma base stand-alone, ou seja, isoladamente. A premissa "em uso", oposta à anterior, parece menos apropriada para instrumentos financeiros. No entanto, um grupo de ativos financeiros pode ser vendido ou carregado em conjunto, e a própria IAS 39 não proíbe que esses ativos sejam valorizados sob uma premissa "em uso".

O valor fundamental, também conhecido por valor em uso, se baseia na estimativa de futuros fluxos de caixa através da vida do ativo ou passivo. No entendimento da SEC (2008, p. 186-187), uma das dificuldades da implementação deste conceito reside na escolha de uma taxa apropriada para descontar esses fluxos de caixa. Se a taxa selecionada for uma taxa corrente de mercado, o valor fundamental tende a convergir para o valor corrente. $\mathrm{O}$ valor justo estimado sob o nível 3, algumas vezes chamado de market-to-model, incorpora o conceito de valor fundamental, embora baseado em previsões dos participantes de mercado, e não em um valor em uso específico da entidade.

Exemplos interessantes podem ser mencionados para instrumentos financeiros tratados em conjunto.

Derivativos normalmente são mensurados pelo seu valor justo, com exceção das operações de hedge, que possuem norma específica. Opções são derivativos que garantem a um comprador, denominado "titular da opção", o direito de comprar ou vender uma quantidade de determinado ativo. No entanto, um conjunto de quatro transações com opções de compra e opções de venda pode construir o mesmo efeito financeiro de um instrumento financeiro préfixado, ou seja, o investidor "aplica" determinada quantia sabendo que, no vencimento das opções, terá direito a um valor já determinado. Esta operação é conhecida como "Box de quatro pontas", e a sua vantagem, em comparação com uma aplicação em renda fixa simples, é a tributação. 
Algumas operações estruturadas também são formadas por um conjunto de ativos e/ou passivos financeiros.

Um exemplo de operação estruturada pode ser montado para um produtor de soja. Esse produtor possui ativos e expectativa de rendimentos diretamente relacionados com a variação no valor de mercado da soja. Se o produtor precisasse de crédito, seria interessante se tivesse a possibilidade de obter um empréstimo indexado à variação do preço da soja, de forma que, quando o preço da soja caísse, o produtor teria menos ativos - mas, ao mesmo tempo, teria uma dívida menor. Por outro lado, quando o preço da soja subisse, ele teria mais ativos, porém, uma dívida igualmente maior. Para atender esse tipo de cliente, os bancos criam operações estruturadas, vinculando operações de crédito ou aplicações com derivativos. No caso do produtor de soja, um banco poderia oferecer uma operação de crédito normal a este cliente, por exemplo, uma operação com pagamento em uma única parcela, no vencimento do contrato, indexada ao CDI. O mesmo banco poderia, simultaneamente, oferecer ao cliente uma operação de swap, onde trocaria o rendimento do CDI pela variação no valor de mercado da soja. $\mathrm{Na}$ operação de swap, o banco e o cliente trocam os rendimentos de um valor de referência, acordado entre as partes. Cada uma das partes "aposta" em um indexador, e no final do contrato, o banco paga para o cliente os rendimentos de acordo com o índice que o cliente contratou. O cliente, de forma semelhante, paga ao banco os rendimentos de acordo com o indexador que este contratou. Na prática, só ocorre o desembolso de uma das partes. Ora, se cada uma das partes do swap fez uma "aposta", e deve pagar ao outro o rendimento do seu indexador sobre o valor de referência, no vencimento do contrato somente a parte perdedora, ou seja, aquela que pagaria um valor maior do que sua contraparte na operação, sofre um desembolso, em valor igual à diferença do maior para o menor rendimento. Para um banco, esse tipo de operação é chamado de operação estruturada, pois o banco concede um crédito, faz uma operação de swap para trocar os indexadores do empréstimo e, normalmente, ainda faz uma transação com o mercado para não ficar exposto ao risco que este apresenta. No exemplo, o banco deveria fazer um hedge para se proteger contra os riscos de variação no valor de mercado da soja. Note-se que nenhuma das transações do banco faz sentido isoladamente, ou seja, o produtor de soja aceitou pegar crédito nesse banco porque vislumbrou a possibilidade de ter um passivo indexado ao mesmo item ao qual seu ativo já era vinculado, a soja. O swap trocando rendimento de CDI por variação do preço da soja, por sua vez, é um componente para viabilizar a operação, ou seja, tornar o empréstimo 
vendável. Por último, se as operações anteriores não existissem, o hedge seria desnecessário. Por isso, o banco poderia tratar esse conjunto de operações como um bloco.

Nos dois exemplos acima, é possível perceber que cada operação isolada talvez nem existisse, mas o conjunto dessas transações produz resultados. Assim, a contabilidade também deveria trabalhar para projetar a essência das operações.

\subsubsection{Técnicas de valuation}

Segundo o IASB, uma técnica de valuation poderia resultar em lucro ou prejuízo desde o primeiro reconhecimento de um ativo. Nesse caso, o lucro ou prejuízo deveria ser reconhecido após o reconhecimento inicial somente se esta diferença do valor transacionado para o valor da técnica surgisse de uma mudança no fator que os participantes de mercado considerariam ao definir preços.

Técnicas de valuation coerentes com o approach de mercado, o approach de receitas e/ou o approach de custos podem ser usadas para mensurar o valor justo. Os conceitos-chave desses approaches são sumarizados abaixo:

\section{- Approach de mercado:}

As técnicas de valuation coerentes com o approach de mercado utilizam preços e outras informações relevantes geradas por transações do mercado, envolvendo transações com ativos e passivos idênticos ou comparáveis. Essas técnicas incluem a utilização de cotações de outros ativos e passivos em um mercado ativo. Se esses ativos ou passivos são idênticos ou comparáveis, assume-se que seus valores podem ser utilizados como base para avaliar os ativos ou passivos correspondentes. $\mathrm{O}$ valor de mercado de uma NTN-B, título público indexado ao IPCA, que paga cupom semestral de $6 \%$ ao ano, por exemplo, poderia ser utilizado como base para precificar um título privado com condições financeiras e de prazo idênticas, se o título privado não tiver um mercado ativo. 
- Approach de receitas:

$\mathrm{O}$ approach de receitas utiliza técnicas de valuation para converter montantes futuros (por exemplo, fluxos de caixa ou lucros) para um simples valor presente (descontado). A mensuração é baseada nas expectativas correntes do mercado sobre esses valores futuros. Essas técnicas de valuation incluem cálculos de valor presente, modelos de precificação de opções, como Black-Scholes-Merton, e um modelo binomial, que incorpora técnicas de valor presente e um método multi-período de ganhos excedentes, que é usado para mensurar o valor justo de certos ativos intangíveis.

\section{- Approach de custos:}

O approach de custos se baseia no montante que correntemente seria requerido para repor a capacidade de serviço de um ativo (frequentemente chamado de custo corrente de reposição). Da perspectiva de um participante do mercado (vendedor), o preço que seria recebido por um ativo é determinado com base no custo para o participante de mercado (comprador) para adquirir ou construir um ativo substituto com utilidade comparável, ajustado por sua obsolescência. Obsolescência engloba deterioração física, obsolescência funcional ou tecnológica, e obsolescência econômica, e é um conceito mais amplo que a depreciação para fins de informes financeiros (uma alocação de custo histórico) ou fins fiscais (baseado em expectativas de vida útil prédefinidas).

\subsubsection{O valor justo em mercados com menor volume ou nível de atividade}

O FSP FAS 157-4 (FASB, 2009, p. 1) enfatiza que, sempre que houver um decréscimo no volume e nível de atividade de um determinado ativo ou passivo, independentemente da técnica de valuation utilizada, o objetivo da mensuração ao valor justo permanece o mesmo, não considerando uma liquidação forçada ou uma venda em situação de stress como uma boa evidência para a determinação do valor justo.

De acordo com FASB (2009, p. 4-5), uma entidade deve avaliar os seguintes fatores para determinar se houve um significativo decréscimo no volume e nível de atividade para certo ativo 
ou passivo, quando comparado com a atividade de mercado normal para esse ativo ou passivo ou itens similares:

a. Existem poucas transações recentes;

b. As cotações não são baseadas em informações correntes;

c. As cotações variam substancialmente ao longo do tempo ou entre market makers;

d. Indexadores que antes eram altamente correlacionados com o valor justo do ativo ou passivo são demonstravelmente não correlacionados com as recentes indicações do valor justo do ativo ou passivo;

e. Há significativo aumento dos prêmios por liquidez implícitos, juros ou indicadores de performance para transações observáveis ou preços cotados, quando comparados com as expectativas de fluxo de caixa da entidade, considerando todos os dados de mercado sobre crédito e outros riscos de não-performance disponíveis;

f. Existe um bid-ask spread muito alto ou um significativo aumento nesse spread;

g. Há significativo declínio ou ausência de um mercado para novas emissões de ativos ou passivos idênticos ou similares;

h. Poucas informações são colocadas a público.

Se uma entidade conclui que houve um decréscimo significativo no volume ou nível de atividade para um ativo ou passivo, os valores de transações ou cotações podem não ser determinantes do valor justo. Uma análise mais detalhada das transações ou cotações é requerida, e um ajuste relevante nesses números pode ser necessário para estimar o valor justo de acordo com a SFAS 157.

O Pronunciamento SFAS 157 não prescreve uma metodologia para fazer esses ajustes. No entanto, o FASB $(2009$, p. 6) afirma que uma mudança na técnica de valuation ou o uso de múltiplas técnicas pode ser uma medida apropriada. O objetivo de usar mais de uma técnica é determinar o ponto dentro do range possível que melhor representa o valor justo. Um range muito grande pode indicar a necessidade uma análise adicional. Uma entidade também deve avaliar, segundo FASB (2009, p. 8), se as cotações existentes se baseiam em informações correntes, que refletem transações corriqueiras, ou se as técnicas de valuation refletem as premissas dos participantes de mercado. Ao usar cotações como entradas para uma estimativa de valor justo, uma entidade deve alocar menos peso às cotações que não refletem o resultado de transações em um mercado ativo. 
Uma medida de valor justo deve incluir prêmios por risco, refletindo o montante que os participantes de mercado descontariam por conta da incerteza dos fluxos de caixa. Em alguns casos, reconhece FASB (2009, p. 8), determinar um prêmio de risco pode ser difícil, o que não deve ser motivo suficiente para ignorar este componente.

FASB (2009, p. 6) afirma que a intenção de manter um ativo ou passivo, em vez de vendê-lo, não é relevante para estimar o valor justo, já que este representa uma mensuração baseada no mercado, e não específica de uma entidade.

\subsubsection{Utilidade da informação contábil}

A Figura 11, abaixo, baseada na SFAC 2 (1980, p. 20), sugere que a utilidade da informação é composta por dois componentes que estão no mesmo nível de importância: relevância e confiabilidade. Trata-se de duas características qualitativas da informação contábil que são consideradas no mesmo nível de importância, e a adição das duas características forma a utilidade, de forma que Utilidade = Relevância + Confiabilidade .

Da formulação acima, pode-se pensar que o uso de entradas observáveis para calcular o valor justo de um ativo ou passivo provavelmente resultará em uma informação com maior utilidade, já que a confiabilidade dos itens observáveis é, obviamente, maior. Porém, quando uma entrada não-observável oferece informações substancialmente mais relevantes, a afirmação anterior não é verdadeira.

Segundo Lisboa, Pigatto e Costa (2000, p. 14), a razão comum para o emprego do valor justo nos procedimentos contábeis é que se reflita a posição patrimonial de um item ou do patrimônio como um todo, de modo que a avaliação evidencie a essência patrimonial e não a mera formalidade legal. De fato, as características perseguidas na avaliação a valor justo são confiabilidade e relevância. A opinião dos autores é a de que a contabilidade deve, acima de tudo, informar. Cada usuário da informação tem o seu próprio modelo decisório, cabendo ao mesmo utilizar ou não tais informações. 


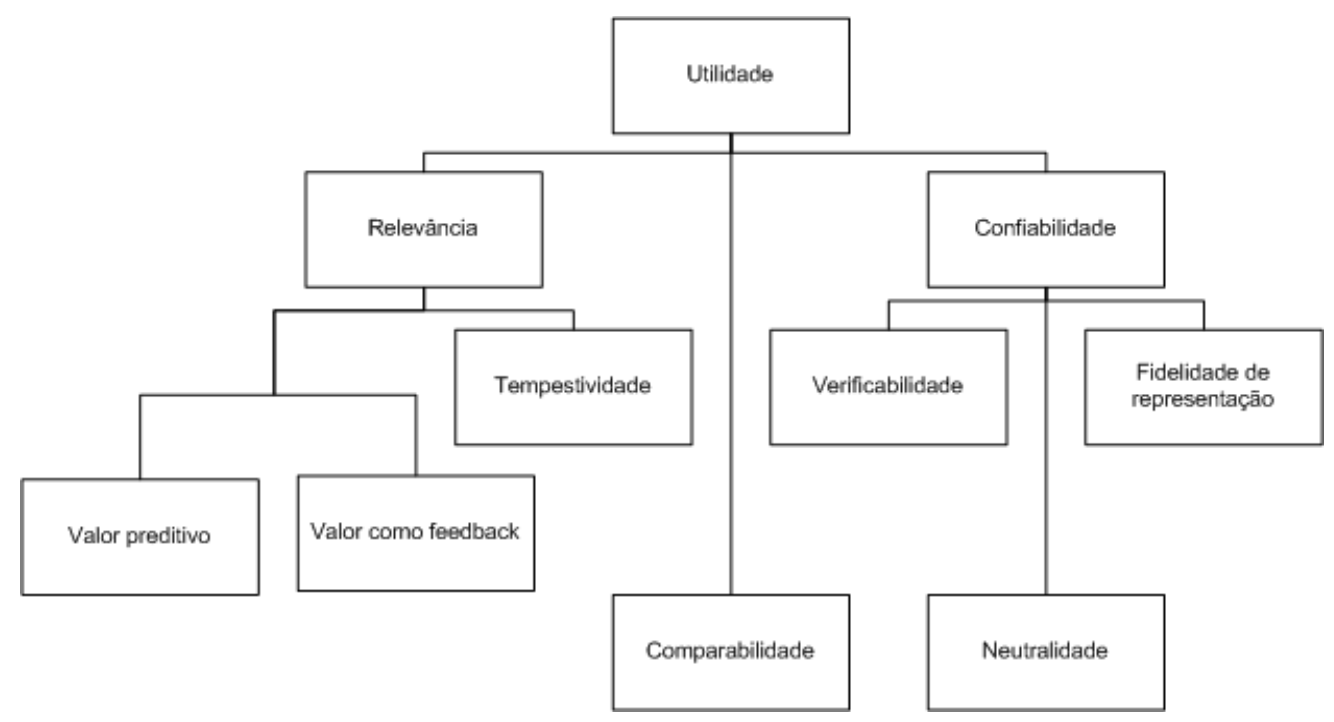

Figura 11: Utilidade da informação contábil - FASB (SFAC 2, p. 20)

Iudícibus, (1978, apud Iudícibus e Martins, 2007) acrescenta a praticabilidade como mais um elemento a ser observado, quando diz que a Contabilidade é um árduo exercício para equilibrar relevância, objetividade e praticabilidade de um determinado procedimento.

\subsubsection{Grandes quantidades de um mesmo ativo}

Quando uma entidade possui grandes quantidades de um único ativo, é comum a preocupação com a influência da liquidez no valor deste ativo, ou seja, o preço de mercado para uma unidade também é aplicável para mil ou para um milhão de unidades? Naturalmente, na maioria das vezes, a resposta para esta pergunta é não.

No entanto, os enunciados da SFAS 157, da SFAS 144 e da IAS 39 não permitem descontos por razão de liquidez, quando a entidade mantém grandes quantidades de um ativo. A justificativa geral é que esse desconto seria específico para uma entidade.

Somente na determinação do valor justo de um instrumento financeiro não negociado em um mercado ativo, a SFAS 157 requer que o preço do instrumento financeiro seja afetado por sua liquidez.

Na opinião deste autor, mesmo sendo atributo específico de uma entidade, as diferenças de valor deveriam ser consideradas na contabilização do valor justo. Isso significa assumir, por exemplo, que a venda de grandes quantidades de um ativo pode influenciar suas cotações. 
Da mesma forma, se uma entidade possui o controle de outra, pode ser inadequado valorizar esta participação utilizando a cotação das suas ações em bolsa, pois esses valores não consideram o direito ao controle da investida.

No exposure draft do IASB (2009, p. 27), este problema é mais bem endereçado. O parágrafo 49 do documento diz que, no caso de uma instituição que mantém grandes quantidades de um mesmo ativo, o preço de mercado (cotação) pode não ser a melhor base para se chegar ao valor justo. Em vez disso, recomenda que sejam utilizados métodos de precificação alternativos, o que resultaria em uma redução do nível de confiabilidade da mensuração, segundo a hierarquia do valor justo.

\subsubsection{Disclosure do valor justo de instrumentos financeiros}

Segundo Iudícibus (2006, p. 123), o disclosure está ligado aos objetivos da Contabilidade, ao garantir informações diferenciadas para os vários tipos de usuários. Hendriksen (1999, apud Iudícibus, 2006, p. 123) destaca as seguintes informações que devem ser reveladas por uma entidade, com o objetivo de não tornar enganosos os seus demonstrativos, no caso de nãodivulgação:

1. Uso de procedimentos que afetem materialmente as apresentações de resultados ou de balanço comparados com métodos alternativos que poderiam ser supostos pelo leitor, na ausência da evidenciação;

2. Mudança importante nos procedimentos de um período a outro;

3. Eventos significativos ou relações que não derivem das atividades normais;

4. Contratos especiais ou arranjos que afetem as relações de contratantes envolvidos;

5. Mudanças relevantes ou eventos que afetariam normalmente as expectativas; e

6. Mudanças sensíveis nas atividades ou operações que afetariam as decisões relativas à empresa.

Em dezembro de 1991, o FASB publicou a SFAS 107, que trata da divulgação de informações a respeito do valor justo de instrumentos financeiros. O pronunciamento recomenda que o valor justo de um instrumento financeiro, quando seu cálculo é praticável, seja divulgado no corpo das demonstrações financeiras ou em notas explicativas complementares. Também 
devem ser divulgados os métodos de avaliação e as premissas relevantes utilizadas no processo de mensuração.

A SFAS 107 lembra que uma instituição financeira não deve confundir um eventual intangível gerado pelo seu relacionamento de longo prazo com clientes com o ativo financeiro propriamente dito. Desta forma, os depósitos passivos devem ser divulgados pelo valor disponível para saque na data da mensuração.

Se a avaliação de um instrumento financeiro não é praticável, a entidade deve divulgar as seguintes informações para o instrumento financeiro ou grupo de instrumentos financeiros:

- Informações pertinentes à mensuração pelo valor justo, como o valor do ativo ou passivo, a taxa de juros efetiva e o maturity;

- As razões pelas quais não é possível a estimativa do valor justo.

De acordo com a SFAS 107 (1991, p. 7), "praticável” é um termo relacionado com o custo da mensuração; por isso, trata-se de um conceito dinâmico. Significa que, em uma entidade, o mesmo processo que foi classificado como "não praticável" por outra instituição, pode ser entendido como praticável, já que os custos e benefícios da avaliação são relativos.

O anexo B da SFAS 107 (1991, p. 11-14) já trazia sugestões para a divulgação do valor justo de instrumentos financeiros, as quais estão organizadas por grupo de ativos ou passivos financeiros, conforme segue.

- Caixa e investimentos de curto prazo: Para instrumentos financeiros de curto prazo, o custo amortizado pode ser uma estimativa razoável do seu valor justo.

- Títulos e valores mobiliários: Para títulos e derivativos mantidos para a negociação, que incluem bônus, futuros, opções, swaps de taxas de juros, contratos em moeda estrangeira e outros, e títulos patrimoniais negociáveis mantidos para fins de investimento, o valor justo deve se basear em preços de mercado ou cotações realizados com compradores ou vendedores interessados. Se não houver preços de mercado para o instrumento avaliado, recomenda-se utilizar o preço de instrumentos semelhantes.

- Recebíveis de empréstimos: Para certas categorias homogêneas de empréstimos, como créditos imobiliários, recebíveis de cartões de crédito, e outros créditos a consumidores, o valor justo deve se basear no valor de mercado de títulos lastreados em operações similares. Caso não seja possível esse tipo de mensuração 
por semelhança, recomenda-se o uso da técnica do valor presente dos fluxos de caixa futuros, utilizando como taxa de desconto uma taxa de empréstimo similar em modalidade, rating do tomador e maturity remanescente.

- Passivos de depósitos: O valor justo de depósitos à vista, depósitos de poupança e outros do mercado monetário, é igual ao montante com liquidez imediata, sob o ponto de vista do depositante, na data de mensuração.

- Dívidas de longo prazo: Taxas correntemente disponíveis para tomar uma dívida com condições e prazo remanescente similares são usadas para estimar o valor justo de obrigações existentes.

- Swaps de taxa de juros: O valor justo de swaps de taxa de juros é o valor estimado que a instituição pagaria ou receberia para encerrar o contrato de swap na data de mensuração, levando em conta as taxas de juros correntes e o risco de crédito da contraparte.

- Limites de crédito não utilizados, cartas de fiança e garantias financeiras prestadas: O valor justo de valores comprometidos é estimado usando as taxas correntemente cobradas para entrar em um acordo similar, levando em conta os termos remanescentes do contrato e o risco de crédito presente da contraparte. Para compromissos pré-fixados, o valor justo deve considerar a diferença entre os níveis correntes das taxas de juros e as taxas contratadas. O valor justo de garantias e cartas de crédito se baseia nas taxas cobradas para entrar em um acordo similar ou nos custos estimados para encerrar ou liquidar o compromisso com as contrapartes na data de mensuração.

A estimativa do valor justo de instrumentos financeiros em uma instituição financeira pode ser divulgada de acordo com a Figura 12: 


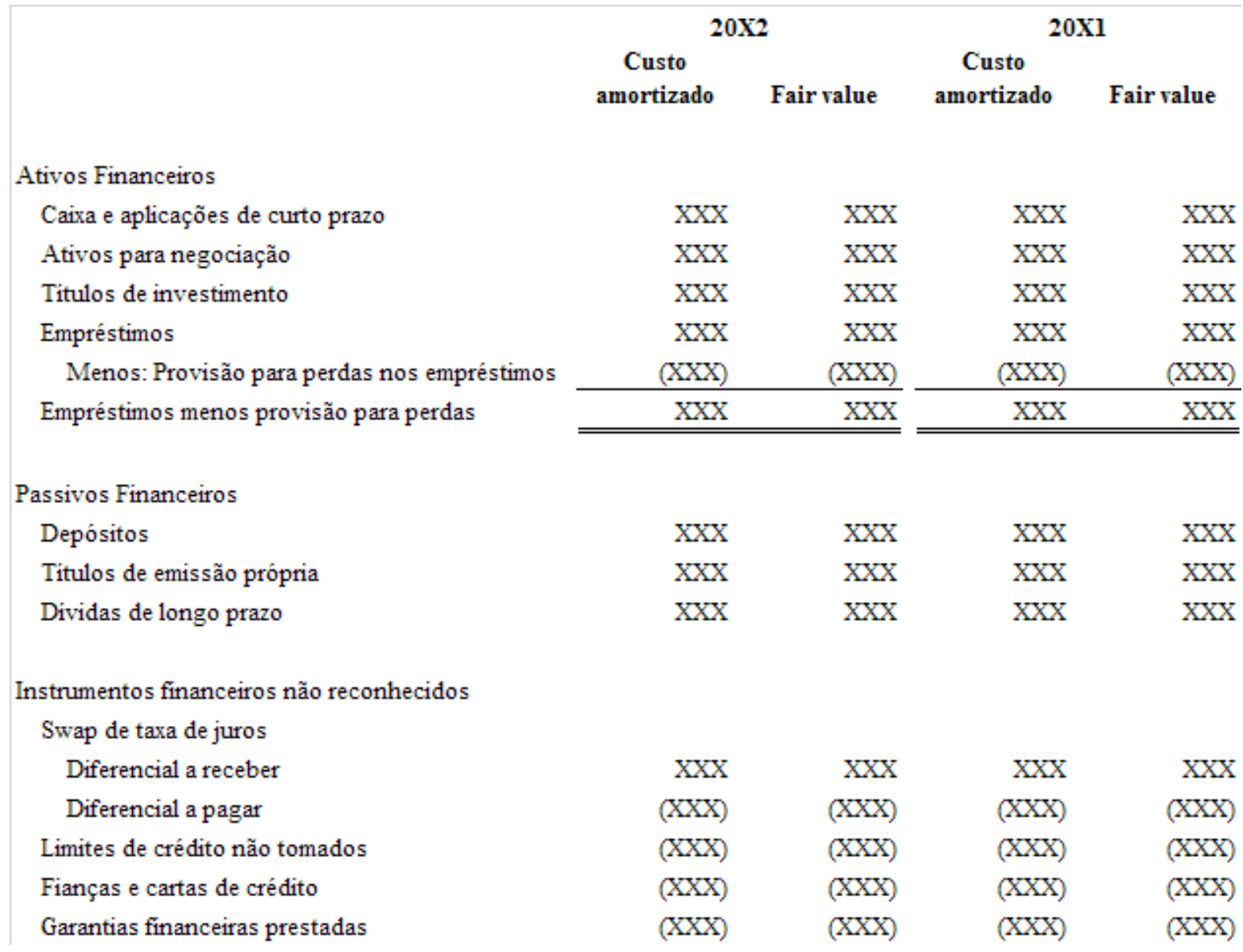

Figura 12: Divulgação do valor justo de instrumentos financeiros em um banco - Fonte: SFAS 107 (1991, p. 11-14)

Em instituições não-financeiras, é recomendável divulgar o valor justo de instrumentos financeiros na forma representada na Figura 13:

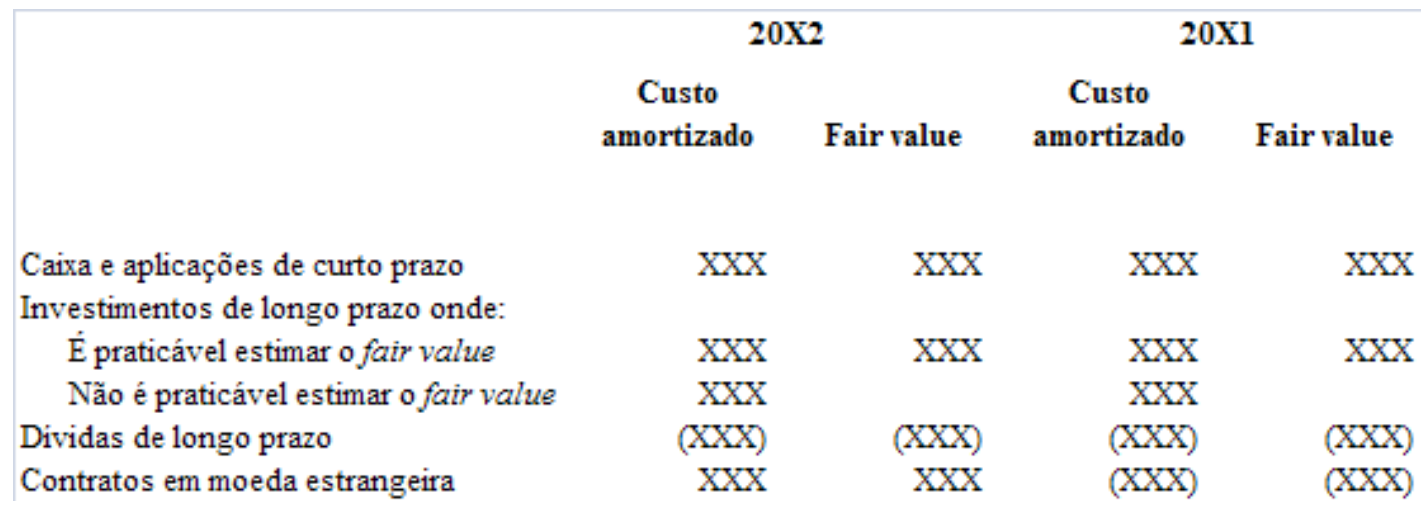

Figura 13: Divulgação do valor justo de instrumentos financeiros em instituição não-financeira Fonte: SFAS 107 (1991, p. 11-14) 
À tabela acima, a instituição ainda deve acrescentar uma explicação sobre por que considerou não praticável a estimativa do valor justo de alguns instrumentos financeiros, incluindo informações sobre o valor dessas operações, taxa de juros efetiva e maturity.

Mais recentemente, a SFAS 157 propôs o disclosure dos seguintes itens relativos à mensuração ao valor justo:

- valor justo na data-base do balanço;

- segregação dos itens mensurados ao valor justo em 3 níveis, de acordo com nível de objetividade da informação de entrada (Hierarquia do valor justo, Nível 1 - Entradas observáveis, como cotações; Nível 2 - Outras entradas observáveis; e Nível 3 Entradas não-observáveis);

- reconciliação dos saldos inicial e final de balanço no caso de alterações significativas nos itens marcados ao valor justo e classificados no Nível 3 da hierarquia do valor justo, considerando:

○ Total de perdas ou ganhos do período, realizados e não realizados, segregando ganhos e perdas reportados na demonstração de resultados. A entidade deve evidenciar onde esses ganhos ou perdas aparecem como alteração no resultado ou como uma mudança nos seus ativos líquidos;

○ Compras, vendas, emissões e liquidações;

- Transferências dos níveis 1 ou 2 para o Nível 3 e deste para o nível 1 ou para o nível 2.

- total de perdas ou ganhos ainda não realizados, referentes a ativos ou passivos que ainda são mantidos pela entidade. A entidade deve evidenciar onde esses valores aparecem nas suas demonstrações financeiras;

- anualmente, as técnicas de valuation utilizadas e as eventuais alterações nessas técnicas devem ser informadas.

A SFAS 157, ao detalhar a definição de valor justo e criar um guia com conceitos e exemplos a respeito do tema, buscou melhorar o nível da informação que era divulgada até então. Mas em termos de exigência de disclosure, a grande inovação da SFAS 157 tem relação com os 
níveis da hierarquia. Para os instrumentos financeiros, a SFAS 107 já exigia uma divulgação bastante completa, porém, a norma publicada em 2006 inseriu novos conceitos e esclarecimentos, o que pode ter enriquecido a informação do valor justo de instrumentos financeiros, hipótese que será testada neste trabalho.

Young (2008, p. 1-6) conta que as grandes instituições financeiras norte-americanas aplicaram a SFAS 157 logo que esta foi publicada, muito antes de se tornar obrigatória. Com isso, os créditos de segunda linha, conhecidos no mercado como subprime, foram registrados pelo seu valor justo, em um momento em que esse tipo de instrumento ainda tinha um grande mercado ativo. Por conta de existirem transações abundantes nesse mercado, foram avaliados sob o Nível 1 da SFAS 157, ou seja, com base em cotações disponíveis no mercado ativo. No entanto, assim que a inadimplência começou a afetar as CDO (Collateralized Debt Obligations), instrumentos que são detalhados na seção 2.3.5 deste trabalho, e os investidores resolveram abandonar esse tipo de operação, o mercado ativo deixou de existir, o que obrigou as instituições a reavaliar seus ativos, desta vez sob os Níveis 2 e 3 da hierarquia. Preparar uma informação útil e, ao mesmo tempo, com a rapidez que os investidores esperavam, não foi tarefa fácil para os contadores, que tiveram de adaptar modelos para avaliar as CDO. O mercado se fechou rapidamente, o que obrigou as instituições a reavaliar seus modelos e premissas, dando munição para os críticos da contabilidade a valor justo. Cada vez mais, a contabilidade mostrava ativos com valores abaixo das expectativas dos investidores, gerando uma frustração totalmente compreensível. Defensores do valor justo argumentam que a volatilidade vista na contabilidade nada mais é do que um reflexo da realidade, algo que em outros regimes contábeis só seria visto por pessoas de dentro das organizações. É claro que evidenciar esta volatilidade, mesmo que ela seja real, nem sempre é algo desejável; porém, esta é apenas mais uma maneira de dizer que "a ignorância é uma benção".

\subsubsection{Other Comprehensive Income (OCI)}

Coelho e Carvalho (2007, p. 8) evidenciam que a prática de registrar algumas reavaliações de ativos/ passivos e/ou ajustes contábeis diretamente no PL, sem o devido trânsito pela DRE, resulta na "contaminação" do incremento no PL por movimentos não reportados, não evidenciados apropriadamente nos relatórios de fluxo de receitas e despesas. Os relatórios de 
mutações do patrimônio líquido, por sua vez, não trazem explicações conceituais, mas somente uma explicitação das variações encontradas do saldo inicial para o saldo final das contas do Patrimônio Líquido.

Para Iudícibus e Martins (2007, p. 7), a contabilidade tradicional, baseada no custo histórico, conceitua o lucro como a diferença entre patrimônios líquidos, após a neutralização das transações de capital com os sócios, como aumento ou diminuição de capital, aquisição e venda das próprias ações e distribuição de resultado. Em uma versão mais rígida, denominada All Inclusive, todas as mutações patrimoniais que não sejam as mencionadas transações de capital transitam pelo resultado, incluindo os ajustes de exercícios anteriores. Na versão oposta, do Operational Income, apenas os itens operacionais e recorrentes são reconhecidos no resultado do período, com todas as demais mutações, inclusive as provisões normais, como despesas de depreciação e provisões de crédito de liquidação duvidosa, sendo refletidas diretamente no Patrimônio Líquido. Esses ajustes efetuados diretamente no Patrimônio Líquido permanecem lá para sempre, nunca passando pelo resultado.

Segundo o Princípio de Realização da Receita, seu reconhecimento está subordinado aos seguintes requisitos:

1. Preço objetivamente definido;

2. Completo desenvolvimento das fases relevantes para a configuração do mérito da receita;

3. Recebimento de dinheiro ou a quase certeza de recebê-lo;

4. Conhecimento das despesas necessárias para a aquisição de tal receita.

Analisando a avaliação de ativos e passivos ao valor justo, é possível perceber que nem sempre variações patrimoniais estarão vinculadas ao reconhecimento de receitas e despesas, como é o caso de instrumentos financeiros classificados como "Disponíveis para a venda", que terão seu ajuste ao valor justo reconhecido no resultado somente no momento de sua realização, quando da sua venda ou transferência para a categoria "Ao valor justo através do resultado".

Para tratar dessas variações, mais especificamente da contrapartida desses ajustes que modificam ativos ou passivos, foi criado um grupo de contas para o registro dos lucros nãorealizados dentro do Patrimônio Líquido. No Brasil, a Lei 11.638/07 criou a rubrica "Ajustes de Avaliação Patrimonial”. 
O FASB, para melhor evidenciar as movimentações nesse grupo de contas, criou a Demonstração do Comprehensive Income, através da SFAS 130, de 1997. Seguindo esta tendência, em 2007, o IASB revisou a IAS 31, e também incorporou o Other Comprehensive Income.

\subsubsection{Aplicação da contabilidade a valor justo}

Sob as USGAPP e as IFRS, o valor justo é o critério de mensuração mais mencionado para ativos e passivos financeiros, de forma oposta aos ativos e passivos não-financeiros, como propriedades e ativos intangíveis.

\section{Títulos patrimoniais (Instrumentos de Equity)}

De acordo com a SEC (2008, p. 25), investimentos em títulos patrimoniais podem ser contabilizados de diversas maneiras. Aqueles que dão o controle a uma entidade geralmente resultam na consolidação do investimento pela investidora, de forma que os ativos e passivos da investida são consolidados com base na sua natureza, de forma proporcional ao percentual de participação da controladora.

Investimentos em títulos patrimoniais de uma entidade na qual a investidora possui influência significativa devem ser apresentados em uma única linha, contabilizados de acordo com o método da equivalência patrimonial. Apesar de estarem baseados no custo histórico, os investimentos consolidados através do método de equivalência patrimonial também estão sujeitos ao reconhecimento de perdas decorrentes de variações no valor justo; porém, essas perdas devem ser reconhecidas somente quando são consideradas perdas já incorridas.

Outros investimentos em títulos patrimoniais, para os quais o valor justo é prontamente determinável, são mensurados pelo valor justo. No entanto, as variações no valor justo podem ser reconhecidas no resultado ou no OCI. Mudanças no valor justo de títulos patrimoniais classificados como trading devem ser reconhecidas no resultado de cada período, enquanto mudanças no valor justo de títulos classificados como AFS devem ser reconhecidos no OCI até que o investimento seja vendido em definitivo ou sofra uma perda por impairment. 


\section{Títulos de dívida}

Conforme citado em SEC (2008, p. 26), insvestimentos classificados como trading devem ser mensurados pelo valor justo periodicamente, com todas as variações no valor justo reconhecidas no resultado do exercício. Em raras circunstâncias, uma companhia pode reclassificar títulos de dívida de ou para a classificação trading. Nas IFRS, a classificação denominada ao valor justo através dos resultados (Fair value through Profit \& Loss - FVTPL) abrange os ativos para trading e os ativos designados para esta categoria através de fair value option, conforme mencionado na seção subsequente deste trabalho.

Títulos de dívida que a companhia adquire com clara intenção e capacidade de manter até o vencimento deve ser designado à classificação mantidos até o vencimento (HTM). Apenas em situações restritas as companhias podem vender títulos HTM ou transferi-los para outras categorias. Títulos HTM são registrados no balanço pelo método do custo amortizado. Reduções no valor justo não são refletidas no balanço ou na demonstração de resultado, exceto no caso de perdas incorridas, quando o valor registrado for maior que o valor justo.

Investimentos que a companhia não classifica como trading (FVTPL para as IFRS) ou HTM são classificados como AFS. Títulos AFS são registrados no balanço pelo valor justo; no entanto, mudanças não realizadas no valor justo geralmente não são registradas no resultado do exercício. Ao contrário, essas mudanças são contabilizadas no OCI do período, até que o investimento seja vendido ou sofra uma perda definitiva. Reclassificações de AFS para HTM são permitidas, desde que a companhia comprove intenção e capacidade de manter o investimento até o vencimento.

De acordo com análise da SEC (2008, p. 49), a menor parte das mudanças em valores de ativos que afetam os resultados são causadas por ativos mensurados pelo valor justo, conforme ilustra a Figura 14.

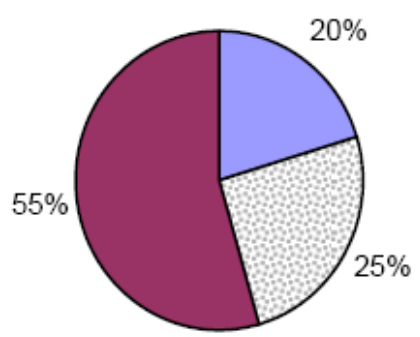


Figura 14: Proporção de ativos para os quais as mudanças no valor justo afetam o resultado, comparado com aqueles que não afetam o resultado e com outros que não são mensurados pelo valor justo, ao final do primeiro trimestre de 2008

SEC (2008, p. 49)

\section{Ativos securtizados}

Alguns ativos passam por um processo chamado securitização, no qual os ativos são transformados em títulos. Em uma securitização típica, lembra SEC (2008, p. 27), a companhia emissora transfere uma carteira de ativos financeiros para uma sociedade de propósito específico, na qual a carteira de ativos é "empacotada".

\section{Investimentos diretos em empréstimos}

A contabilização de operações de empréstimo é diferente quando o mesmo é mantido para investimento (HFI) ou quando é mantido para venda (HFS), de acordo com SEC (2008, p. 27). Geralmente, os empréstimos HFI são contabilizados pelo custo amortizado, com impairment reconhecido apenas para prováveis perdas de crédito.

Empréstimos HFS são contabilizados pelo menor valor entre custo ou valor justo, com reduções no valor justo reconhecidas no resultado.

Companhias podem transferir seus empréstimos entre as categorias HFI e HFS. Como alternativa, a companhia pode mensurar uma carteira de empréstimos pelo valor justo, independentemente da intenção de vender esta carteira.

Nos pronunciamentos do IASB, a contabilização de empréstimos é substancialmente diferente, não tendo segregação entre HFI e HFS. A regra de mensuração pelo valor de custo ou de mercado, dos dois o menor, também não existe nas IFRS.

\section{Derivativos}

Os derivativos não designados como instrumentos de hedge são mensurados pelo valor justo, de acordo com requerimentos do IASB e do FASB, com mudanças no valor justo sendo registradas imediatamente no resultado do exercício. Para derivativos designados como hedge de fluxo de caixa, as mudanças no valor justo (ganhos ou perdas não realizados) são registradas e acumuladas no OCI, e reclassificadas para o resultado somente quando o fluxo de caixa protegido impactar o resultado do exercício. Ao passo que para derivativos designados como hedge de valor 
justo as mudanças no valor justo do instrumento e no objeto de hedge são registradas diretamente nos resultados.

\section{Passivos financeiros}

Atualmente, as USGAAP não requerem a mensuração recorrente de passivos pelo valor justo, exceto quando se trata de passivos decorrentes de instrumentos derivativos. No entanto, a SFAS 159 inseriu a opção de mensurar um passivo pelo seu valor justo (fair value option). A mensuração de passivos deve considerar alterações na classificação de crédito do mutuário. Assim, um declínio na classificação de crédito da entidade resulta no reconhecimento de um ganho, já que o valor justo dos seus passivos é reduzido.

Nos pronunciamentos do IASB, existem duas categorias de passivos financeiros: Passivos Financeiros ao Valor Justo através dos Resultados (FVTPL) e Outros Passivos Financeiros. A primeira categoria, como sugere o nome, requer que passivos sejam mensurados pelo valor justo, e que essas mudanças sejam contabilizadas no resultado. Na categoria FVTPL são classificados os passivos que serão negociados no curto prazo, além da fair value option, mencionada a seguir.

\section{Fair Value Option (FVO)}

A opção pelo valor justo permite, mas não obriga, que as entidades elejam certos ativos e passivos à mensuração pelo valor justo, com contrapartida no resultado. A FVO, presente nos pronunciamentos do FASB e do IASB, tem o objetivo de reduzir a volatilidade nos resultados reportados causados pela mensuração de ativos e passivos de formas diferentes, sem incorrer na aplicação de regras complexas de hedge accounting.

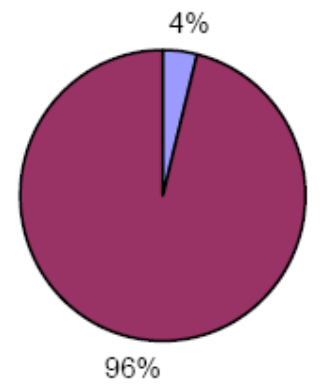

Figura 15: Fair value option de ativos financeiros - SEC (2008, p. 55) 
Estudo da SEC (2008, p. 55) mostra que a opção pelo valor justo não era utilizada em grande escala no final do primeiro trimestre de 2008, conforme ilustra a Figura 15. Para os passivos, a aplicação da fair value option é ligeiramente maior, de acordo com estudo da SEC, Figura 16.

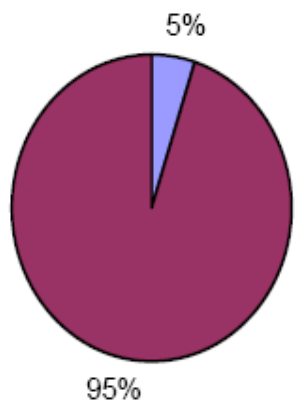

口Fair Value Option Liabilities

口All Other Liabilities

Figura 16: Fair value option de passivos financeiros - SEC (2008, p. 70)

Na Figura 17, pode-se visualizar a distribuição dos passivos mensurados ao valor justo, de acordo com sua natureza.
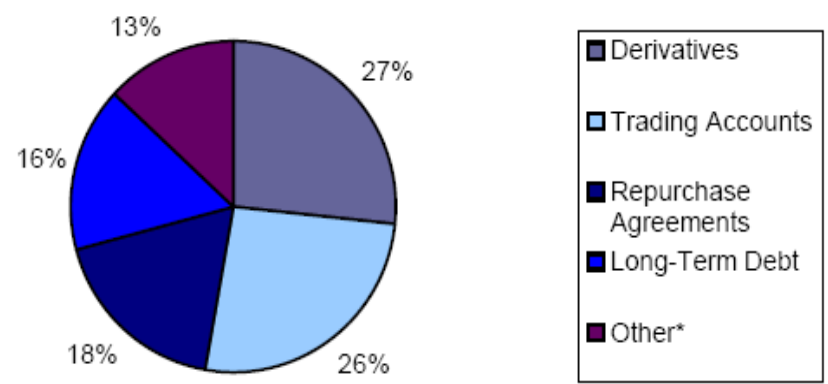

Figura 17: Natureza de passivos mensurados ao valor justo - SEC (2008, p. 74)

A Figura 18, abaixo, ilustra a distribuição da natureza de ativos mensurados ao valor justo, mostrando a maior relevância dos investimentos em títulos de dívida e títulos patrimoniais, e dos instrumentos mantidos com a intenção de negociação. 

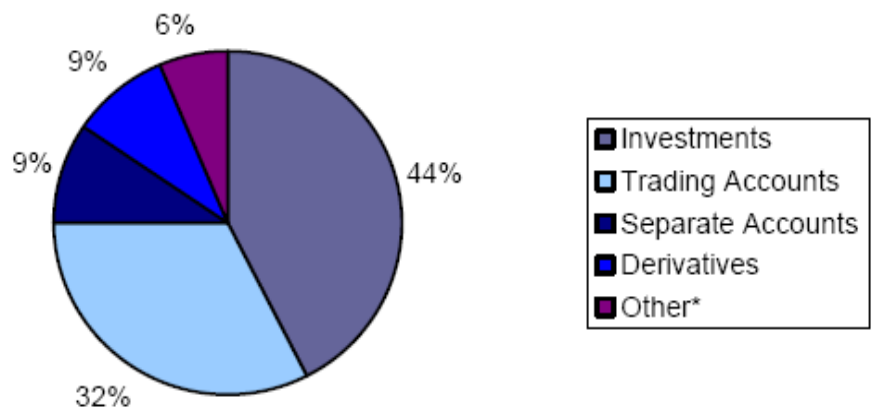

Figura 18: Natureza dos ativos mensurados ao valor justo - SEC (2008, p. 60)

\section{Impairment}

Conforme a SEC (2008, p. 30), a perda por impairment em ativos não sujeitos à marcação a mercado pode ser diferente, dependendo das características do ativo. Por exemplo, um empréstimo para investimento (HFI Loan) normalmente sofre perda por impairment quando é provável que o credor não terá condições de honrar com suas obrigações. A mensuração da perda por impairment é baseada na estimativa da administração da entidade sobre perdas de crédito incorridas. Um título de dívida ou patrimonial geralmente sofre uma perda por impairment quando seu valor contábil (normalmente baseado no custo amortizado) excede o valor justo. Para títulos com perdas por impairment, apenas as perdas não temporárias resultam em uma nova mensuração do valor justo, com mudanças no valor justo sendo reconhecidas nos resultados.

A recente crise econômica global destacou dificuldades nas avaliações de perdas por impairment não temporárias, particularmente no que se refere ao cálculo do valor justo de certos instrumentos financeiros.

\section{IFRS versus USGAAP, de acordo com SEC (2008, p. 31-32)}

- AS IFRS não diferenciam investimentos em títulos de dívida e investimentos em empréstimos. Sob as IFRS, independentemente da forma contratual, investimentos com pagamentos fixos ou determináveis podem ser reconhecidos como empréstimos ou recebíveis, quando não são negociados em um mercado ativo e o investidor não tem intenção de vender o investimento no curto prazo. 
- Antes de outubro de 2008, quando as normas sofreram ajustes em resposta à crise, as IFRS possuíam requerimentos mais restritivos que as USGAAP para regular a transferência de ativos financeiros entre categorias.

- Sob as IFRS, o fator gerador para reconhecimento do impairment difere das USGAAP.

- As perdas por impairment de títulos HTM são reconhecidas nos resultados nas IFRS e nas USGAAP. No entanto, sob as USGAAP, as perdas por impairment são reconhecidas em relação ao valor justo do ativo, enquanto, sob as IFRS, elas são reconhecidas somente para perdas incorridas.

- As IFRS possuem grandes restrições do uso da opção pelo valor justo através dos resultados.

Em resposta à crise, em outubro de 2008, o IASB ajustou a IAS 39, permitindo que ativos financeiros não derivativos mantidos para negociação ou disponíveis para a venda sejam reclassificados em determinadas situações. A emenda permite a uma entidade reclassificar ativos da categoria FVTPL para outras, em situações particulares. Também permite transferir ativos da categoria AFS para $L \& R$, desde que o ativo se enquadre nas definições de $L \& R$, e a entidade tenha intenção e capacidade financeira para mantê-lo até o vencimento. As USGAAP já permitiam esse tipo de transferência entre categorias.

\section{Valor justo em instrumentos não-financeiros, segundo as USGAAP}

Em geral, os ativos e passivos não-financeiros não são avaliados pelo valor justo recorrentemente, sendo a princípio mensurados pelo valor de custo. Adicionalmente, esses ativos podem ter seu valor reduzido quando o valor justo é menor que o valor contabilizado, de acordo com os requerimentos de impairment. Por outro lado, quando o valor justo aumenta em relação ao valor contábil, a regra geral é que este aumento não seja refletido no valor contábil do ativo.

\section{Combinação de negócios}

Sob a SFAS 141, o adquirente é requerido a mensurar muitos dos ativos e passivos adquiridos em uma combinação de negócios pelo valor justo. Mesmo que vários ativos estejam registrados pelo custo histórico nos livros da companhia vendedora, eles devem ser reavaliados 
ao valor justo no momento da aquisição. A SFAS 141 ainda requer a identificação e o reconhecimento de ativos intangíveis pelo valor justo. A SFAS 141 fala somente sobre a mensuração inicial a valor justo, mas não requer reavaliações subsequentes sob uma base recorrente.

\section{Goodwill}

Embora o goodwill não seja mensurado pelo valor justo, ele representa um valor residual depois da dedução de outros montantes do balanço que foram mensurados na data de aquisição. A cada ano, ou até mais frequentemente, o goodwill deve ser testado por impairment.

\section{Ativos intangíveis com vida útil indefinida}

Assim como o goodwill, os intangíveis com vida útil não definida devem ser testados por impairment a cada ano, ou até com maior frequência, na ocorrência de eventos que possam resultar em perdas.

\section{Outros ativos de longo prazo}

As USGAAP requerem que outros ativos de longo prazo, como propriedades, fábricas, equipamentos e outros intangíveis com vida útil finita, sofram ajustes por impairment em certas circunstâncias (por exemplo, quando os fluxos de caixa esperados de um ativo ou grupo de ativos é menor do que o valor contábil). Adicionalmente, os ativos de longo prazo mantidos para a venda devem sofrer ajustes por impairment de acordo com o seu valor justo menos os custos de venda.

Conforme a SEC (2008, p. 33-34), as IFRS diferem das USGAAP no uso do valor justo para instrumentos não-financeiros em dois aspectos básicos: Primeiro, as IFRS consideram a FVO de ativos não-financeiros, como propriedades, fábricas, equipamentos e investimentos em propriedades, mas não para direitos de hipotecas, como permitido pelas USGAAP. Segundo, as IFRS requerem a reversão de perdas por impairment quando o valor do ativo volta ao normal. 


\subsection{A CRISE FINANCEIRA MUNDIAL}

Muitos economistas e autoridades monetárias, de acordo com Krugman (2008, p. 4-5), acreditavam que entre John Maynard Keynes e Milton Friedman o mundo havia aprendido o suficiente para evitar crises como a depressão de 1929; porém, há cerca de uma década, no período da crise asiática dos anos 1990, perceberam que esta crença não estava correta.

Segundo Wolf (2009, p. 37), em seu livro sobre globalização financeira, Frederic Mishkin diz que as crises, em geral, resultam de pelo menos um de dois erros fundamentais:

- Má gestão da liberalização;

- Indisciplina fiscal.

A análise pós-fato é, sem sombra de dúvidas, muito mais fácil do que a percepção desses erros durante os períodos em que tudo vai bem. Em 2003, informa Krugman (2008, p. 9-10), Robert Lucas, vencedor do Prêmio Nobel de 1995, após explicar que a macroeconomia foi iniciada como resposta à grande depressão, declarou que o problema de prevenção a depressões estava resolvido. Ele não reclamou dos ciclos econômicos, com alternância irregular de recessões e expansões, mas reclamou que os ciclos têm sido domados de tal forma que futuras suavizações das ondas de crescimento econômico produziriam apenas ganhos triviais. Portanto, era tempo de mudar o foco de atenção, em busca de um crescimento de longo prazo.

Quando o sistema evolui em sentido ascendente, vai ganhando força e, impulsionado, produz efeitos cumulativos, mas gradualmente vai perdendo potência, até que ocorre a substituição por uma força em sentido contrário, que também vai se intensificando, fortalece-se, e acaba por ceder lugar a forças contrárias, ensina Keynes (1982, p. 243). Este é o princípio dos ciclos econômicos.

Keynes (1982, p. 244) explica movimento cíclico como forças ascendentes e descendentes que não persistem indefinidamente na mesma direção, mas acabam por inverter-se. Para complementar a explanação, ainda insere o conceito do fenômeno da crise - fato em que a substituição de uma fase ascendente por uma descendente ocorre de maneira repentina e violenta.

No início deste milênio, não era difícil encontrar opiniões incentivando o laissez-faire, como forma de aproveitar a volatilidade dos ciclos econômicos para obter ganhos de longo prazo. A partir de meados de 2007, no entanto, grande parte do mercado reviu suas opiniões, e clamou 
pela interferência de governos e órgãos multilaterais no sentido de amenizar os efeitos de uma crise que se iniciava e da qual não se tinha ideia de sua dimensão.

As imprensas escrita, de rádio e de televisão, além das revistas científicas, se referiram à primeira grande crise do terceiro milênio por diversos nomes, como crise financeira internacional ou mundial, crise econômica mundial, crise de liquidez, crise de crédito, crise imobiliária, crise do subprime, crise iniciada no verão - americano - de 2007, crise mundial, crise global, entre outros.

Moura (2008, p. 18-19) aponta sete fatores que levaram o mundo à atual crise financeira:

a. Novo modelo de negócio de banco comercial: originar e distribuir, em vez de originar e manter até o vencimento. Neste modelo, os empréstimos bancários são retirados do balanço dos bancos de origem, fazendo com que os investidores tenham menor interesse em monitorar a situação do devedor original. Com a securitização, os bancos antecipam as receitas das operações de crédito e, ao mesmo tempo, diminuem a necessidade de capital regulamentar.

b. Coexistência de operações entre um conjunto de instituições regulamentadas e outras instituições frouxamente reguladas ou sem nenhuma regulamentação. $\mathrm{O}$ exemplo mais ostensivo desta última situação refere-se aos hedge funds.

c. Crescimento das operações nos mercados de balcão, sem registro centralizado, sem transparência na formação de preços e com maior risco pela não exigência de depósitos de margem.

d. Opacidade dos ativos de alguns players do mercado, particularmente, os hedge funds.

e. Administração de risco nas instituições financeiras baseada em regras convencionais de estabelecimento de limites de crédito de contraparte, método que deixa de funcionar em situações de estresse, devido à dificuldade de avaliar a capacidade de pagamento do devedor e a qualidade dos ativos dados como garantia.

f. Elevados níveis de alavancagem nos segmentos menos regulados do mercado.

g. Remuneração dos executivos das instituições financeiras, que incentiva a assunção de riscos, pois os ganhos são compartilhados pelos executivos e acionistas, enquanto as perdas são totalmente alocadas aos investidores.

Em poucas palavras, Nakano (2008, p. 14-15) resume a crise, informando que o problema de insolvência dos empréstimos imobiliários subprime impactou todo o sistema financeiro, por 
conta da securitização das hipotecas subprime e da alavancagem excessiva das instituições financeiras. As insolvências geram retrações na liquidez, e estas, por sua vez, causam perdas nos valores dos ativos. Isto gera necessidades maiores das instituições financeiras venderem ativos, com deságio, para honrarem seus compromissos. A consequência deste processo de retroalimentação é que o fundamento das transações financeiras e da concessão de crédito, a confiança, é destruído, pois torna-se impossível calcular o risco das contrapartes.

Soros (2008, p. 123-124) culpa a globalização, a liberalização, o boom das commodities, a ascensão da China e inovações financeiras (como instrumentos financeiros sintéticos, cálculos de risco e modelos de negócio) pela grande crise de 2007. Segundo ele, a crise do subprime foi simplesmente o gatilho que deflagrou o desmonte de uma super-bolha.

O chamado segmento subprime, segundo Carta do IBRE (2008, p. 6), acolhe tomadores de crédito hipotecário com episódios de inadimplência ou retomada de imóvel em passado recente, ou que tenham passado por falência pessoal (possível nos Estados Unidos), ou que gastem $50 \%$ ou mais da sua renda com o serviço da dívida.

\subsubsection{A preparação da crise}

Greenspan (2008, p. 11) julga que esta é a mais traumatizante crise em mais de meio século, e atribui as raízes da "bolha" imobiliária e da bolha acionária de fins da década de 1990 à seguinte sequência de eventos:

1. Abandono quase universal do planejamento central;

2. Adoção da economia de mercado praticamente no mundo inteiro;

3. A entrada de meio bilhão de pessoas nas forças de trabalho das novas economias emergentes.

Soros (2008, p. 13-14) também acredita que as raízes da crise vinham sendo cultivadas muito antes. Em resposta ao estouro da bolha da internet, no final do ano 2000, o Fed cortou sua taxa básica de juros de 6,5\% para 3,5\% e, em seguida, para combater os efeitos negativos advindos dos atentados de 11 de setembro de 2001, continuou baixando a taxa, até chegar a $1 \%$ em julho de 2003. Durante 31 meses, a taxa de juros de curto prazo real ficou negativa. 
O crédito barato deu origem a uma bolha imobiliária. Segundo Soros (2008, p. 14), quando o dinheiro é de graça, o emprestador racional continua emprestando até que não haja ninguém mais a quem fazê-lo.

El-Erian (2008, p. 18) afirma que os participantes do mercado começam a tomar consciência de transformações no cenário econômico por meio de "ruídos", e um ruído vem da repentina emergência de anomalias em relacionamentos estabelecidos e considerados estáveis. Em geral, as pessoas tendem a ignorar os efeitos de longo prazo desses ruídos, mas eles podem ser importantes, desde que contenham sinais de mudanças fundamentais que não tenham sido captados pelas ferramentas de monitoramento tradicionais.

Os três seguintes fatores provocaram mudanças seculares (mudanças de longo prazo) que resultaram em anomalias no cenário econômico mundial, conforme El-Erian (2008, p. 25):

- Realinhamento do poder e da influência da economia global, incluindo o deslocamento gradual para um conjunto de países que antes tinham pouca ou nenhuma influência sistêmica.

- Acumulação de riqueza nas mãos de países que costumavam ser mais devedores do que credores. Isso alimentou a influência dos fundos estatais, e o desejo de diversificar investimentos atraiu a atenção de políticos dos países industrializados.

- Proliferação de novos instrumentos financeiros que alteraram profundamente as barreiras de entrada em muitos mercados.

A interação desses três fatores resultou em profundas mudanças nos propulsores e nas relações-chave na economia e nas finanças globais, gerando diversas formas de ruído. Os mercados colidem à medida que entram em cena novas considerações, dificultando o desenvolvimento de ferramentas de análise adequadas. Como as interligações dos mercados estão mudando, a diversificação já não traz aos investidores a mesma comodidade que trazia antes.

A taxa de crescimento dos países emergentes no início do terceiro milênio tornou-se muito maior que a dos países desenvolvidos, de acordo com Greenspan (2008, p. 12), e como a propensão a poupar dos países emergentes é maior do que a dos países desenvolvidos, os emergentes inundaram o mercado financeiro em uma velocidade não acompanhada pelos investimentos da economia real; logo, as taxas de juros de longo prazo caíram drasticamente em todo o mundo. Com isso, assistiu-se à queda da inflação mundial, impulsionada pela competição internacional. 
Embora admita que estudos empíricos não sustentem esta afirmação, as transações internacionais, de acordo com Wolf (p. 28-29), estão mais sujeitas a crises, pois as pessoas compreendem melhor a economia e o comportamento dos agentes de seu próprio país do que os de países estrangeiros. Por outro lado, os cidadãos mais ricos de países em desenvolvimento depositam maior confiança no comportamento e nas instituições dos países avançados do que em suas próprias economias.

Wolf (2009, p. 16) entende que os direitos de propriedade devem ser definidos com exatidão e aplicados com rigor. Também devem ser desenvolvidas normas e práticas contábeis confiáveis, deve-se garantir a boa governança corporativa e zelar pela preservação de registros exatos e completos. Nos Estados Unidos, tudo isso existe em grau avançado, embora ainda incompleto. As famílias americanas confiam nas organizações com as quais se relacionam. Assim, o sistema financeiro americano se ergue sobre uma sofisticada base institucional. E, talvez mais importante, ele se fundamenta no comportamento e nos valores sociais que sustentam essas instituições.

El-Erian (2008, p. 29-30) lembra que, em 2005, Alan Greenspan, a Revista The Economist e Larry Summers, professor de Harvard e ex-secretário do Tesouro dos Estados Unidos, alertaram para mudanças que ainda faziam parte de um enigma. Summers, especificamente, referiu-se à nova configuração dos balanços de pagamentos globais, em que o grande fluxo de capitais ocorre dos países em desenvolvimento para os países industrializados, ou seja, dos pobres para os ricos, o que desafiava não só os manuais de economia como a própria lógica. Summers e os demais preocuparam-se com as implicações ainda desconhecidas do fato.

As figuras 19 e 20 mostram as poupanças, investimentos e conta corrente dos países de alta renda e dos mercados emergentes e países exportadores de petróleo, respectivamente. Em conjunto, as figuras ilustram a inversão dos balanços de pagamento em meados do ano 2000, assim como os níveis de poupança dos países em desenvolvimento superaram o montante dos investimentos, gerando poupança líquida. 


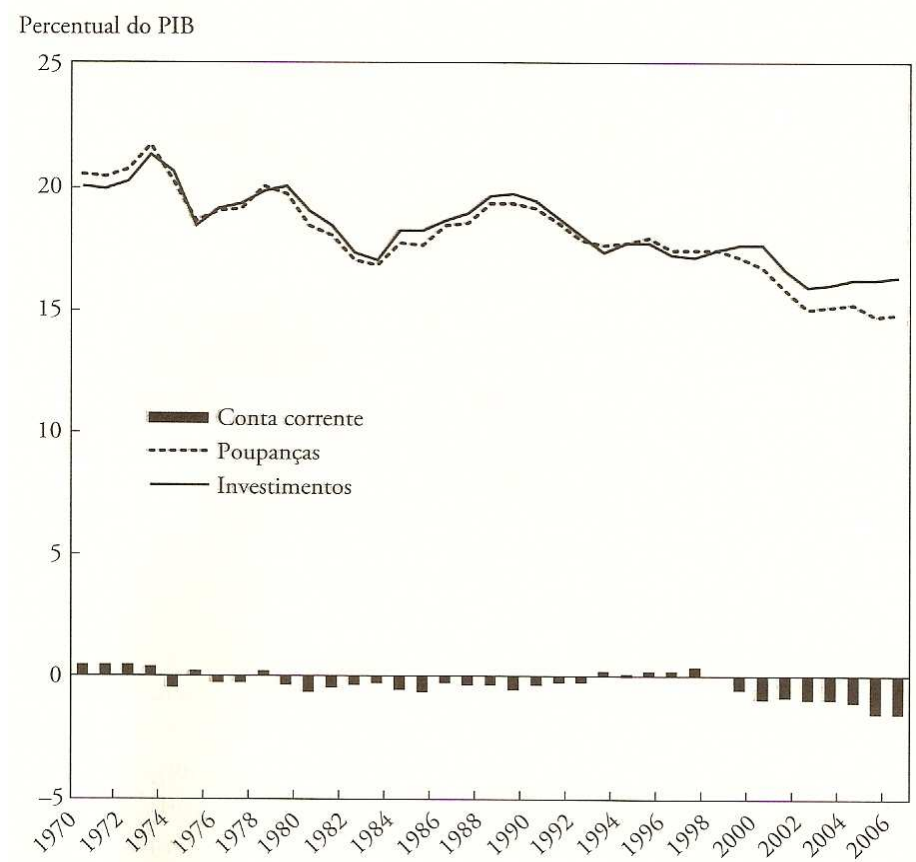

Fonte: Fundo Monetário Internacional, World Economic Outlook, abril de 2007.

Figura 19: Poupanças, investimentos e conta corrente dos países de alta renda Fonte: Wolf (2009, p. 68)

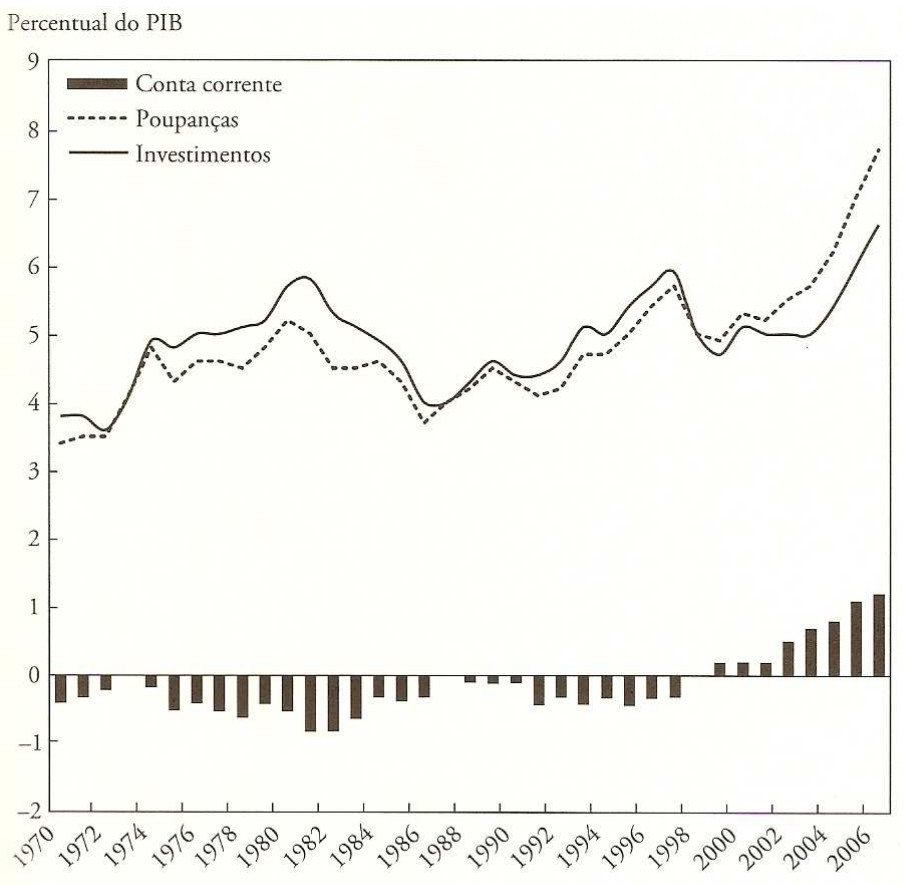

Fonte: Fundo Monetário Internacional, World Economic Outlook, abril de 2007.

Figura 20: Poupanças, investimentos e conta corrente dos mercados emergentes e dos países exportadores de petróleo - Fonte: Wolf (2009, p. 69) 
Wolf (2009, p. 43-44) atribui as inversões nos saldos de conta corrente dos países em desenvolvimento à imensa volatilidade da oferta de fundos do setor privado, que passou longos períodos de otimismo em relação às economias de mercados emergentes, os quais foram seguidos por surtos muito parecidos com pânico.

El-Erian (2008, p. 38-43) fala sobre um enigma das taxas de juros: Ao mesmo tempo que o Federal Reserve aumentava as taxas de curto prazo dos títulos federais, notava-se uma tendência de queda nas taxas de juros de longo prazo, conforme evidencia a Figura 21. A razão para este fenômeno, segundo ele, é a busca dos Bancos Centrais dos países em desenvolvimento, com cofres abastecidos, por títulos de baixo risco, independentemente de seus rendimentos. Instrumentos de equities dos Estados Unidos registraram sucessivos recordes de alta, ao mesmo tempo em que a curva de rendimentos se invertia.

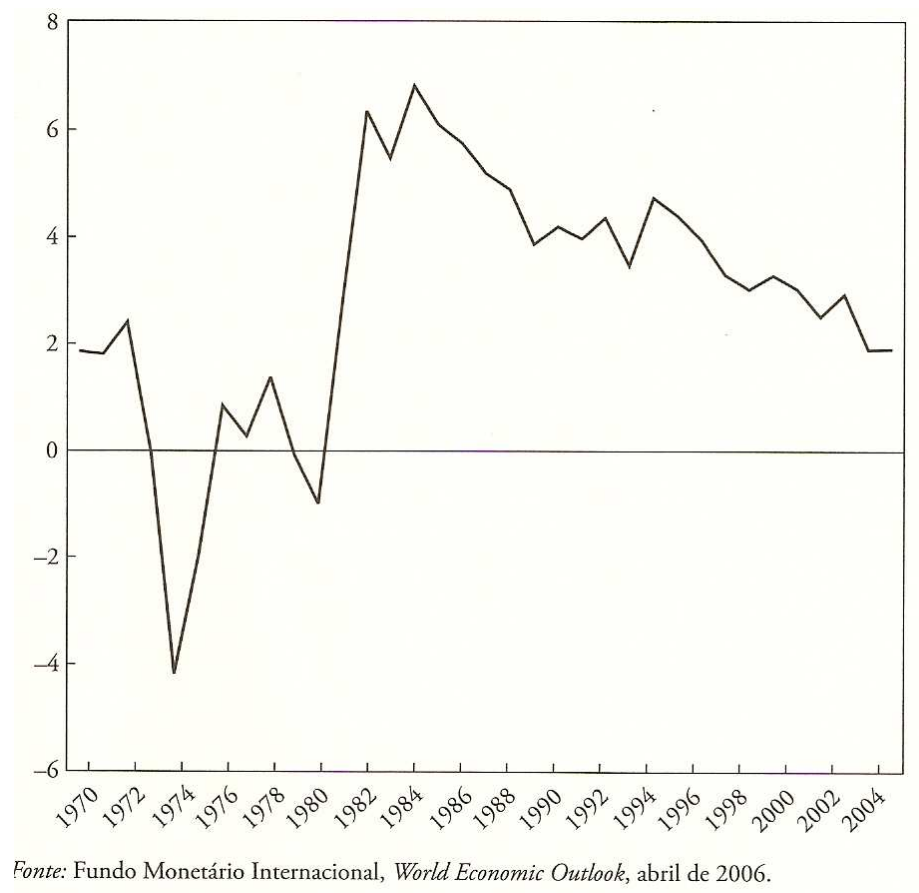

Figura 21: Taxa de juros real de longo prazo no mundo Fonte: Wolf (2009, p. 62)

O cenário de queda nas taxas de juros de longo prazo e inflação cedente resultou em forte alta nos preços dos ativos financeiros e imóveis, conforme lembra Greenspan (2008, p. 13). 


\subsubsection{Prêmios mais baixos e riscos mais altos}

É consenso que o estopim da crise foi a sub-precificação do risco em todo o mundo, pois os investidores passaram a aceitar riscos muito mais elevados em troca de retornos um pouco maiores.

A crise foi causada pela pressão política iniciada no governo Clinton, e mantida no governo Bush, para que as agências hipotecárias gigantes Fannie Mae e Freddie Mac relaxassem seus critérios de concessão de crédito, de acordo com Carta do IBRE (2008, p. 6). A ideia era tornar viável o acesso à casa própria para uma população que antes era excluída.

Aproveitando o cenário político, as instituições financeiras montaram uma engrenagem que estabelecia um vínculo do valor do imóvel com o ganho dos bancos, através de uma multa que o mutuário pagaria quando renegociasse seu contrato em condições mais vantajosas. Esse mecanismo incentivou as instituições a refinanciar esses clientes de risco em condições mais frouxas, acompanhando a valorização das residências.

Todo o ganho, informa Soros (2008, p. 17), da contratação original à colocação final, baseava-se em comissões, de forma que, quanto maior fosse o volume de operações, maior seria o ganho.

De acordo com Greenspan (2008, p. 14-15), durante os anos de surto de preços, os níveis de inadimplência e execuções de hipotecas haviam sido enganosamente baixos, já que o excesso de liquidez provia recursos para novos empréstimos e refinanciamentos hipotecários com base no valor patrimonial atualizado do imóvel, menos o saldo devedor corrente. Altos rendimentos decorrentes de securitização fizeram os fundos de hedge, fundos de pensão e bancos em todo o mundo clamarem por esses produtos. Assim, os emprestadores de subprime facilitaram ainda mais a concessão de créditos, já que o mercado secundário deixava a operação aparentemente sem riscos.

As autoridades monetárias também tiveram papel fundamental na expansão do crédito. Segundo Stiglitz (2004, p. 221), as autoridades monetárias e os agentes reguladores podem afetar o comportamento dos bancos, não só por meio de variações na taxa dos títulos públicos de curto prazo, mas também alterando restrições e incentivos.

Para El-Erian (2008, p. 30), o maior quebra-cabeças está centrado na significativa queda nos prêmios pagos aos investidores para assumir riscos versus o desejo desses investidores por 
assumir ainda mais riscos de baixo preço. Esperava-se correlação negativa entre esses dois fenômenos, mas por um longo período eles mostraram correlação positiva. Alguns investidores hesitavam em aceitar prêmios baixos. Em decorrência disso, contraíram empréstimos para aumentar seu montante disponível para investir, e assim, alavancaram seus rendimentos. Desta forma, a demanda de uma grande porção de investimentos fez com que os prêmios por risco baixassem ainda mais, incentivando outras rodadas de alavancagem. Em vez de aguardarem maiores explanações, muitos investidores lançaram-se em negócios cada vez mais arriscados. Os produtos financeiros, cada vez mais complexos, em alguns casos, ofereciam "alavancagem embutida", favorecendo aqueles que procuravam maiores retornos.

Galbraith (2007, p. 265-266) diz que a legislação e o conhecimento econômico mais ortodoxo não protegem o indivíduo e a instituição financeira em momentos de euforia, levandoos, quando isso acontece, a questionar o aumento dos valores da riqueza, e à corrida participativa que aumenta os preços e ao colapso final. Alguns artefatos capturam a mente financeira ou, talvez, com maior exatidão, o que se passa por tal. O preço do objeto da especulação sobe. Esse aumento e a perspectiva dele atraem novos compradores, que garantem novos aumentos, e assim sucessivamente. Esse processo, quando reconhecido, é claramente evidente e, em particular, após os fatos. Shiller (2008, p. 69) entende que a bolha do setor imobiliário foi incentivada pelo mito de que, em função do crescimento populacional e da escassez de terras, os preços dos imóveis inevitavelmente tenderiam a subir ao longo do tempo.

Galbraith destaca dois tipos de participantes da especulação: em maior número, aqueles que são induzidos a pensar que, por alguma nova situação, os preços aumentarão indefinidamente e, em menor número, aqueles ligeiramente mais astutos, que percebem a tendência especuladora do momento, pretendem aproveitá-la, e acreditam que saberão o momento certo de abandonar suas posições.

O evento especulador nunca termina com um lamento, mas com um choque, pois quando alguns daqueles mais astutos decidem que é o momento de sair, provocam uma reação dos demais participantes, que também decidem vender suas posições, resultando sucessivas perdas até chegar a um verdadeiro colapso.

Para se salvar, é preciso resistir a duas forças imperativas, segundo Galbraith (2007, p. 266):

- O poderoso interesse pessoal que se desenvolve na crença eufórica; 
- A pressão da opinião pública financeira, aparentemente superior, aplicada em favor de tal crença.

Todos os envolvidos com especulação e que experimentam um aumento na riqueza desejam pensar que este fato é resultado da sua própria visão ou intuição superior, de acordo com Galbraith (2007, p. 267). De modo prático, a especulação domina a inteligência dos envolvidos no processo. Um elemento que reforça a tendência eufórica é a condenação que o público e a opinião financeira dirigem àqueles que exprimem dúvida. Alegam que esses últimos são incapazes, devido a alguma inadequação mental, de aprender as circunstâncias novas e recompensadoras que sustentam e garantem o aumento dos valores, ou que sua motivação é suspeita.

Galbraith (2007, p. 268-269) cita alguns exemplos, inclusive o caso de Paul M. Warburg, o mais respeitado banqueiro do seu tempo e um dos fundadores do Federal Reserve System, que foi arduamente criticado quando denunciou uma especulação descontrolada no inverno de 1929, e que haveria um colapso desastroso, se ela continuasse.

Para Keynes (1982, p. 245), as últimas etapas da expansão econômica são caracterizadas por expectativas otimistas relativas ao rendimento futuro dos bens de capital suficientemente fortes para compensar a abundância crescente desses bens, a alta de seus custos de produção e, provavelmente, também a alta da taxa de juros. Wolf (2009, p. 29) afirma que muitos economistas hoje aceitam que a mudança das expectativas pode criar numerosas situações de equilíbrio autorrealizadoras, em que os maus ou bons resultados são consequência das expectativas.

\subsubsection{O estouro da bolha}

Além disso, o pessimismo e a incerteza em relação ao futuro reforçam a preferência por liquidez, estimulando um aumento na taxa de juros. O impacto negativo de uma crise no valor de mercado de títulos também afeta a propensão a consumir, justamente quando ela é mais necessária, segundo Keynes (1982, p. 247). Isso decorre da influência depressiva dos resultados financeiros em bolsa sobre a disposição dessas pessoas para gastar.

De acordo com El-Erian (2008, p. 31), nenhum mentor político americano ou multilateral incentivou medidas efetivas para elevar a taxa de juros e cortar a euforia no "melhor da festa". 
No primeiro semestre de 2006, de acordo com Carta do IBRE (2008, p. 6), o preço das casas parou de subir, piorando o desempenho dos produtos estruturados a partir de hipotecas subprime. Evidentemente, este impacto tornou-se mais drástico a partir do início de 2007.

A Carta do IBRE (2008, p. 6) sugere um breve histórico dos acontecimentos relacionados à deflagração da crise:

- Fevereiro de 2007: Surgiram os primeiros sinais de crescimento da inadimplência em hipotecas do segmento subprime nos Estados Unidos.

- Maio de 2007: A Agência Moody’s reviu para baixo a nota de 62 quotas de 21 contratos de produtos financeiros estruturados a partir de subprimes.

- Junho de 2007: Outras agências de rating seguiram o movimento iniciado pela Moody's.

- Julho de 2007: A venda de casas novas caiu 6,6\%, comparando com o mesmo mês do ano anterior.

Com todos esses sinais, era de se esperar um aumento na volatilidade dos mercados, porém, o VIX, índice de volatilidade da Bolsa de Chicago, apresentava volatilidade comportada de julho de 2003 até meados de julho de 2007, conforme pode ser observado na Figura 22.

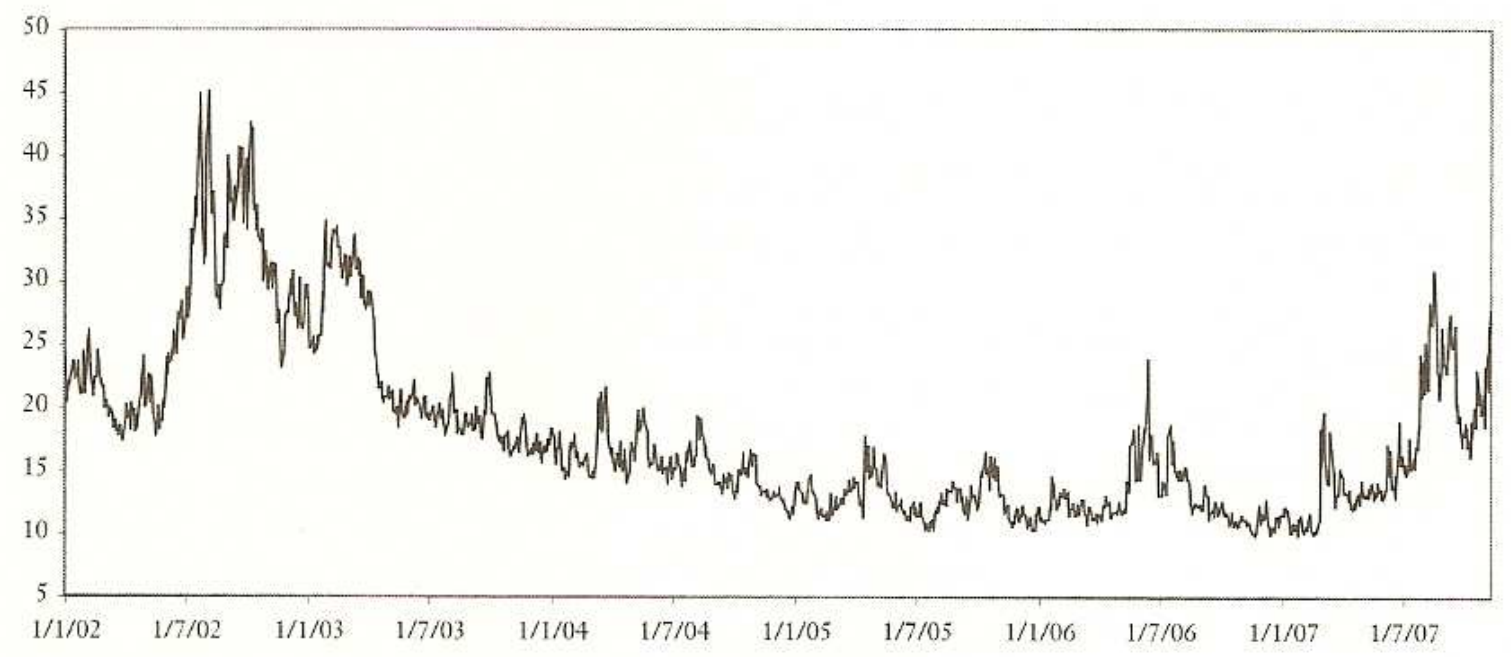

Fonte: Bloomberg.

Figura 22: Evolução do VIX 
Fonte: El-Erian, p. 52

Para Soros (2008, p. 12-13), o início da crise pode ser oficialmente fixado em agosto de 2007. O primeiro acontecimento relevante foi o pedido de concordata da American Home Mortgage, uma das maiores empresas de financiamento imobiliário e hipotecas dos Estados Unidos, em 6 de agosto de 2007, logo após demitir a maioria de seus funcionários.

Greenspan (2008, p. 3) lembra que em 9 de agosto de 2007 o BNP Paribás suspendeu os negócios de três dos seus fundos, afirmando que não poderia mais avaliar os ativos do fundo, pois seu mercado havia evaporado. Em poucas horas, os mercados de crédito de curto prazo em todo o mundo praticamente pararam. As grandes perdas sofridas pelos empréstimos hipotecários subprime desencadearam a crise; porém, problemas com outros produtos ou mercados financeiros teriam produzidos os mesmos efeitos.

Ainda no início de agosto de 2007, segundo Soros (2008, p. 21), os mercados financeiros entraram em pânico, quando o Bear Stearns pediu proteção contra os credores de dois fundos de hedge expostos a empréstimos subprime e impediu que os clientes sacassem de um terceiro fundo.

$\mathrm{Na}$ sequência desses acontecimentos, assistiu-se a uma série de injeções de liquidez capitaneadas pelos bancos centrais dos países desenvolvidos, em especial o Banco Central Europeu, o Federal Reserve e o Banco Central do Japão.

\subsubsection{Regulamentação e supervisão}

Para Nakano (2008, p. 14-15), a crise dificilmente poderia ter sido evitada com maior supervisão e regulamentação do sistema financeiro, pois ela decorre da nova ordem monetária e financeira criada na década de 1980, que combinou novas tecnologias da informação, globalização, inovações financeiras e liberalização dos mercados. Essas inovações financeiras, particularmente dos derivativos, ampliaram fantasticamente a capacidade do sistema financeiro de prover liquidez imediata. É esta explosão de liquidez financeira que vinha provocando inflação no valor dos ativos financeiros. Pode-se falar em geração de valores fictícios, e que a crise veio para destruir esses valores, como na queda de um castelos de cartas. 
Com opinião distinta, Goodhart (2008, p. 11) acha que a regulamentação deveria contar com instrumentos que permitissem aos reguladores atenuar "bolhas" nos preços dos ativos. A combinação de um acordo de Basileia II com uma contabilidade marcada a mercado dos valores dos ativos dos bancos é muito pró-cíclica. Embora não julgue que a regulamentação tenha causado a crise, o autor acredita que fez agravar muito a situação.

O Ato da SEC (2008, p. 2006) deixa claro que as USGAAP não deveriam ser estabelecidas ou modificadas para atender às necessidades de outros usuários em detrimento dos investidores, que são os principais usuários da informação contábil. Desta forma, o FASB não deveria se preocupar com o impacto da contabilidade no capital regulatório, nem com seu consequente efeito pró-cíclico, caso essas preocupações reduzissem a confiança do investidor.

De acordo com Carta do IBRE (2008, p. 7), as agências de rating, pelos acordos de Basileia I e Basileia II, e também pela regulação específica de vários países, concentraram muito poder, o que redundou numa pressão dos clientes para que baixassem os critérios de avaliação. Isto, por sua vez, resultou em uma inflação dos ratings - as mesmas notas, ao longo do tempo, passaram a representar riscos maiores. Os bancos de investimento deveriam ter sido regulados de forma bem mais rígida. No caso do Lehman Brothers, por exemplo, constatava-se que seus níveis de alavancagem eram por demais elevados, e que apresentavam descasamentos muito graves em seus balanços.

Para El-Erian (2008, p. 48), os organismos multilaterais também decepcionaram como reguladores ou conselheiros. O FMI não tinha expertise suficiente para discutir os novos produtos financeiros e por isso não era visto como um conselheiro confiável. Além disso, como os países em desenvolvimento não necessitam mais de recursos financeiros do Fundo, seu poder de enforcement foi reduzido drasticamente. Com menos empréstimos concedidos, seus rendimentos caíram, o que levou o Fundo a um cenário de contração orçamentária, justamente em um período em que precisava de poder político e financeiro. Como outro agravante, a legitimidade do FMI e do Banco Mundial tem sido contestada, pois a posição de chefe do FMI sempre tem sido reservada para um europeu, enquanto a presidência do Banco Mundial é reservada a um norteamericano. 


\subsubsection{Inovações financeiras: CDO, CDS, PDS e SIV}

Bookstaber (2008, p. 257-258) afirma que os mercados estão se tornando mais propensos a crises, e aponta os efeitos da inovação como um dos culpados deste problema. Sem negar os efeitos positivos das inovações, como tornar os mercados mais eficientes, mais líquidos e mais rápidos para reagir às informações, o autor entende que a inovação não só aumenta a complexidade, como também torna os mercados mais acoplados entre si. O forte acoplamento e o aumento de liquidez daí resultante facilitam a assunção de posições mais alavancadas, já que títulos mais líquidos e prontamente precificados representam uma garantia melhor.

No caso do objeto deste estudo, nota-se que, em vez de emprestar e manter os créditos em carteira, os bancos comerciais vendiam suas hipotecas de mais alto risco para corretoras, que em seguida vendiam esses créditos em blocos aos bancos de investimento, que os reembalavam em instrumentos de securitização chamados de CDO - Collateralized Debt Obligations.

Os fundos de hedge especializados em crédito atuavam como companhias de seguro não licenciadas, de acordo com Soros (2008, p. 18), cobrando prêmios sobre as CDO e outras obrigações que seguravam.

Para explicar como funciona uma obrigação de dívida com garantia, Bonfim (2007, p. 147), utiliza um exemplo físico, e não financeiro. Imagine um reservatório de água no alto de uma montanha, o qual, ao ser totalmente preenchido, transborda, fornecendo água ao tanque imediatamente abaixo. O segundo tanque, quando estiver cheio, repetirá o fenômeno de transbordar e ceder água ao próximo tanque. Todo mês os tanques são esvaziados e começam a ser preenchidos pelo tanque mais alto, de forma que, se a água acaba antes de preencher todos os tanques, aqueles reservatórios mais baixos ficam com pouca ou nenhuma água. Assim funcionam as $\mathrm{CDO}$, que são títulos com diferentes níveis de senioridade e com pagamentos de principal e juros suportados pelos fluxos de caixa de um portfólio de instrumentos de dívida como objeto. Desta forma, um título com maior senioridade tem prioridade no recebimento, enquanto os títulos com menor senioridade possuem maior risco de não recebimento, o que é compensado, na maioria das vezes, por uma taxa de remuneração maior ou pela exigência de investimentos menores. Quando os instrumentos de dívida são empréstimos, a CDO é chamada de CLO (obrigações garantidas por empréstimos); se são bônus, a CDO torna-se CBO (obrigações garantidas por bônus). 
Para ilustrar a explicação, Bonfim (2009, p. 148-150) utiliza a figura 23. Considere um emissor de CDO com um portfólio de empréstimos no valor de face total de \$ 100 milhões. Para financiar a compra de empréstimos, o emissor vende obrigações de dívida (notas) a investidores. A corrente de pagamento prometida para essas notas, por sua vez, é garantida pelos fluxos de caixa gerados pelo portfólio de empréstimos. A figura desenha o caso relativamente comum em que o emissor da CDO é uma SPV - Special Purpose Vehicle. Suponha que ambos, os empréstimos que constituem o colateral e as notas, fazem pagamentos mensais. A cada mês, o emissor (SPV) recebe os pagamentos devidos aos empréstimos e os transfere aos investidores que compraram as notas (já líquidos de qualquer taxa administrativa).

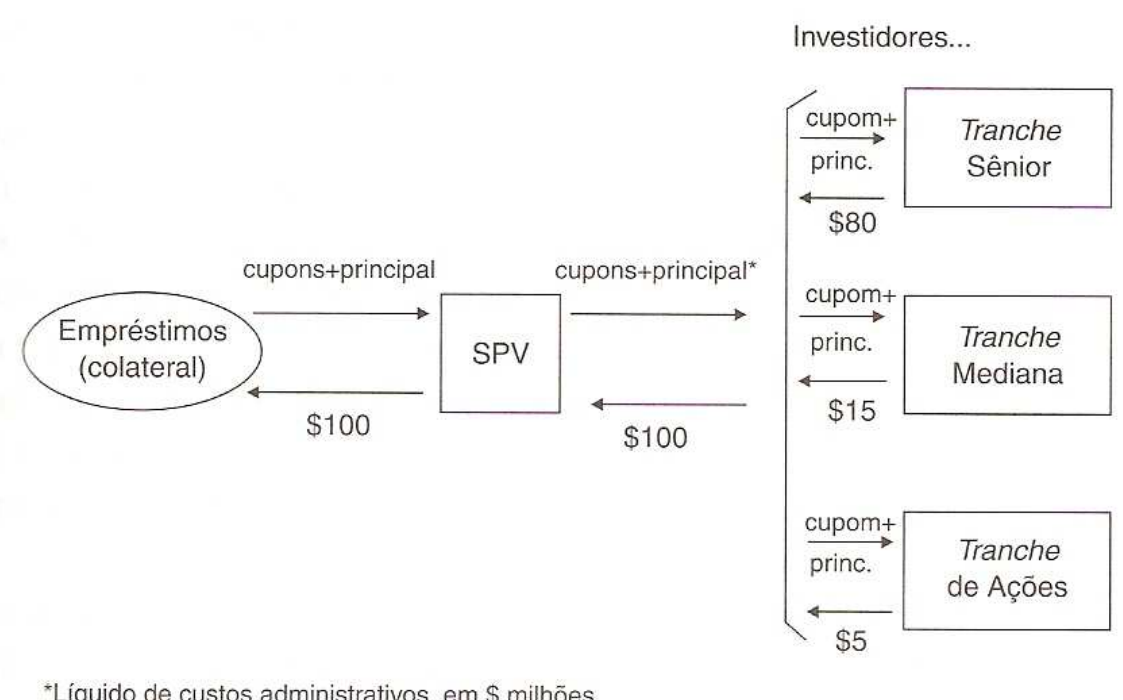

Figura 23: Fluxo simplificado de uma CDO

Fonte: Bonfim (2007, p. 149)

$\mathrm{O}$ aspecto-chave de uma CDO é que as notas possuem diferentes cupons para refletir os vários níveis de risco e senioridade. Em particular, a cada mês, toda a renda paga pelos empréstimos-objeto é usada primeiro para realizar o pagamento das notas sênior. Na linguagem técnica, cada nível de senioridade das notas emitidas sob uma CDO é chamado de tranche. As tranches são tipicamente classificadas pelas principais agências de classificação de risco de crédito.

As CDO foram largamente utilizadas, em geral, para atingir os seguintes objetivos de seus patrocinadores: 
- Excluir ativos do balanço patrimonial, liberando capital regulatório;

- Alavancar suas exposições ao risco de crédito, em operações nas quais as instituições por trás das emissões tentam melhorar seus retornos sobre os ativos-objeto, tornandose investidores de primeira perda nas estruturas criadas;

- Criar liquidez para empréstimos bancários que, de outra forma, seriam ativos sem liquidez.

Grande parte dos subprime securitizados, de acordo com Greenspan (2008, p. 17), foi vendida no exterior, e boa parte dessa securitização assumiu a forma de obrigações creditícias garantidas (CDO), em que as tranches com prioridade no recebimento eram certificadas pelas agências de rating como AAA.

Soros (2008, p. 18) recorda que, antes da invenção dos CDS - Credit Default Swaps, um banco interessado em diversificar sua carteira de ativos teria de comprar ou vender partes de empréstimos, o que era complicado, pois dependia da anuência do tomador.

Um credit default swap, explica Bonfim (2007, p. 76), é um acordo bilateral entre um comprador e um vendedor de proteção de crédito. Em sua forma mais simples, o comprador de proteção concorda em fazer pagamentos periódicos sobre um predeterminado número de anos (o vencimento do CDS) ao vendedor de proteção. Em troca, o vendedor de proteção compromete-se a fazer um pagamento ao comprador no caso do evento de crédito da terceira parte. Como tal, o credit default swap compartilha de muitas similaridades com produtos de seguros tradicionais.

Já o portfolio default swap (PDS), é um instrumento por meio do qual o comprador de proteção protege parte da sua carteira de crédito. Diferente do CDS, que protege o comprador contra perdas relacionadas a uma única entidade de referência, ou de um basket default swap, que protege contra perdas em uma cesta relacionada a um determinado grupo de entidades de referência, o PDS protege o comprador de proteção contra perdas em uma carteira de crédito, sem que sejam nomeadas entidades de referência. Para ilustrar um PDS de primeira perda (first loss portfolio default swap), Bonfim (2007, p. 121) dá o exemplo que segue:

Suponha que o banco está prevendo que as chances de experimentar perdas relacionadas com inadimplência que excedam $10 \%$ sobre o próximo ano sejam suficientemente pequenas, de forma que aceita-se tolerar esse risco. O banco pode entrar num portfolio default swap de um ano com um investidor que deseja vender proteção contra os primeiros $10 \%$ de perdas relacionadas 
com inadimplência que ocorrer na carteira. $\mathrm{O}$ investidor estará disposto a quantas inadimplências individuais forem necessárias para produzir uma perda de 10\% na carteira de referência.

Aumentando um pouco mais o nível de complexidade das transações, Bonfim (2007, p. 152-154) mostra o funcionamento de uma CDO sintética. A figura 24 mostra um banco comercial, rotulado como banco patrocinador, com uma carteira de empréstimos de $\$ 100$ milhões (ativos de referência). O banco deseja remover o risco de crédito associado com a carteira, mas, em vez de vender os empréstimos para um repackaging vehicle (rotulado como SPV - Special Purpose Vehicle - na figura), o banco opta por vender somente o risco de crédito associado com a carteira e manter os empréstimos em seu balanço patrimonial.

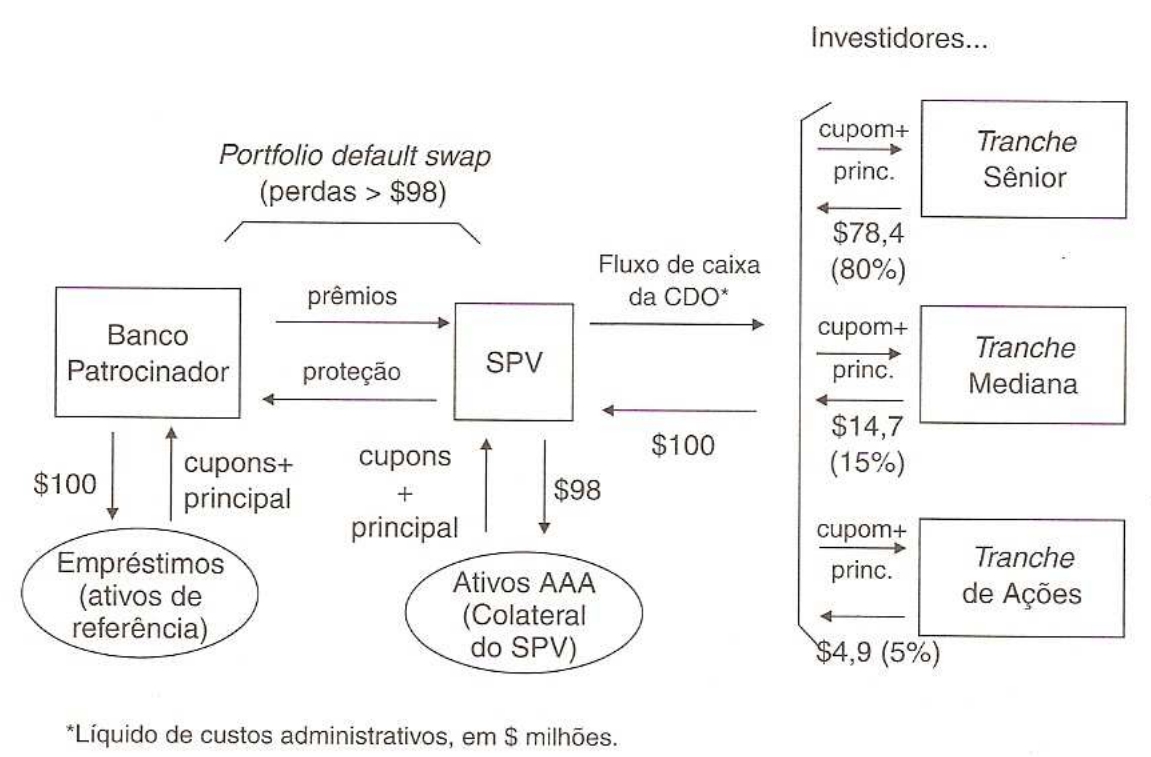

Figura 24: Diagrama de uma CDO Sintética Simples Fonte: Bonfim (2007, p. 153)

A transferência do risco é feita por meio de um portfólio default swap no qual o SPV é a contraparte e a entidade patrocinadora compra proteção contra qualquer perda que exceda $2 \%$ da carteira, no exemplo. Como no caso das CDO tradicionais, o patrocinador tende a manter uma pequena parcela de primeira perda, $2 \%$ nesse caso, em parte para acalmar as preocupações de investidores potenciais. O banco faz pagamentos de prêmios periódicos ao SPV, que se compromete a cobrir qualquer perda com inadimplência que exceda o percentual acordado de $2 \%$ da carteira, como em qualquer contrato de portfólio default swap. 
Em seguida, o SPV, assim como numa estrutura de CDO tradicional, emite notas para várias classes de investidores, onde cada classe corresponde a exigências com um dado nível de senioridade em relação aos fluxos de caixa do SPV. No entanto, como o portfólio default swap é uma estrutura não-financiada, os fluxos de caixa que ele gera não podem compensar completamente os investidores tanto por seus custos de financiamento (as notas emitidas pelo SPV são investimentos completamente financiados) como pelo risco de crédito embutido no portfolio de referência. Para resolver essa desvantagem, o SPV investe os ganhos da venda das notas em ativos com classificação alta (AAA). Então, o SPV utiliza esses ativos tanto como colateral para suas obrigações junto ao banco patrocinador e aos investidores, quanto por meio da renda que ele gera, como uma fonte de fundos para complementar os pagamentos de cupons prometidos pelas notas.

Um SIV - Structured Investment Vehicle - é um tipo de SPV, ou seja, uma estrutura isolada da entidade patrocinadora, que possui ativos, passivos e estrutura patrimonial próprios. Os SIV normalmente investem em ativos de longo prazo, como uma CDO, e captam no curto prazo, através de commercial papers. Em geral, esta captação é baseada em ABCP's - AssetBaked Commercial Papers, que são commercial papers com valor garantido pelo fluxo de caixa de um conjunto de ativos.

Com a eclosão da crise do subprime, o ciclo de refinanciamento constante foi quebrado, pois os investidores temiam que os ativos que garantiam os ABCP's, notadamente as hipotecas, contivessem porções de créditos subprime. A figura 25 , que mostra a evolução de diversas formas de commercial papers, mostra uma impressionante queda no volume de ABCP's. 


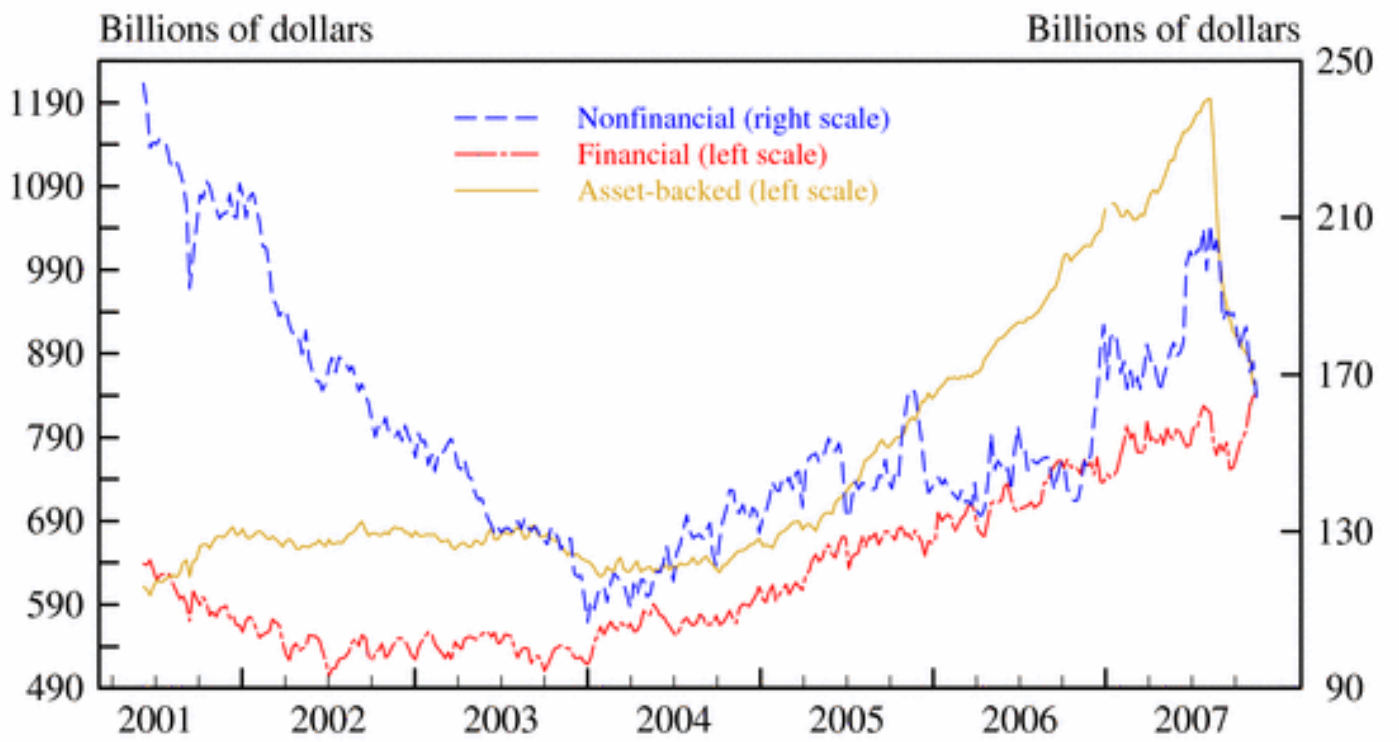

Figura 25: Evolução de várias formas de papel comercial Fonte: http://www.thinkfn.com/wikibolsa/Imagem:ABCPChart.gif

\subsubsection{Precificação e contabilização}

Segundo Greenspan (2008, p. 17-18), foi a incapacidade de atribuir preços adequados a esses ativos arriscados que preparou o palco para a crise. El-Erian (2008, p. 32) acredita que as estratégias convencionais e os modelos de negócios não captam mais de maneira adequada a dinâmica real da economia global.

Quando os mercados finalmente desprezaram as avaliações otimistas, passou-se a questionar a precificação de todas as $\mathrm{CDO}$ e outros produtos financeiros exóticos, como os Veículos Financeiros Estruturados (Structured Investment Vehicles - SIV), notas promissórias comerciais lastradas em ativos (Asset-Backed Commercial Paper- ABCP), e CDO squared.

Os bancos de investimento mantinham grandes posições de CDO fora dos balanços nos SIV. Esses SIV financiavam suas posições emitindo títulos lastreados em ativos. Quando o valor das CDO passou a ser duvidoso, segundo Soros (2008, p. 21), a maioria dos bancos absorveu os SIV em seus balanços e foi forçada a admitir pesadas perdas. Em 26 de novembro de 2007, o HSBC anunciou a consolidação de investimentos que estavam em SIV ligados ao Banco, recorda El-Erian (2008, p. 53). Após este evento, outros bancos acompanharam o HSBC. 
Outro problema, segundo Goodhart (2008, p. 11), é a demasiada fé em modelos de avaliação de riscos complexos, aos quais falta bom senso. $\mathrm{O}$ mundo financeiro necessita de procedimentos muito mais simples e diretos, contando com mais historiadores econômicos e menos físicos e matemáticos.

Greenspan (2008, p. 39-40) tem opinião diferente. Ele acredita que, por mais complexos que sejam, nossos modelos de risco e econômicos ainda são simples demais para captar o conjunto das variáveis que governam a realidade econômica global.

O ex-presidente do Federal Reserve reforça sua tese, informando que, nos últimos 50 anos, apenas em um período correspondente a um sétimo do período todo, a economia americana esteve contraída. Nos seis sétimos restantes, a economia americana viveu tempos de expansão. Com isso, os modelos de risco e econômicos geralmente são desenvolvidos sob uma premissa expansionista. Em alguns casos, ativos que possuem correlação negativa na fase expansionista podem perder essa característica no período de crise, solapando a estratégia de diversificação de investimentos dos participantes do mercado.

O grande desafio nesse sentido, acredita Greenspan (2008, p. 41), é modelar separada e adequadamente cada ciclo e identificar os sinais que identificam a iminência de mudança de um ciclo para outro.

Os primeiros problemas com créditos subprime surgiram na Europa e nos Estados Unidos em meados de 2007, mas a situação agravou-se muito no segundo semestre de 2008, culminando em uma crise sistêmica, a partir da quebra do Lehman Brothers. Segundo Carta do IBRE (2008, p. 7), a preferência por liquidez derrubou os preços dos ativos menos líquidos, e o mecanismo da marcação a mercado intensificou o movimento de queda, ao mostrar instantaneamente cada filigrana do processo de deterioração.

Segundo Yokoi (2008, p. 15), em tempos de crise, o modelo do preço justo se revelou muito frágil. O preço de negociação deixou de ser um valor tido como justo e virou sinônimo de perdas astronômicas e irreais. O jornalista conta que, em maio de 2008, a seguradora AIG, que apresentava perdas significativas em seus ativos financeiros, sugeria aos reguladores dos Estados Unidos da América que repensassem a exigência da marcação a mercado. Mais recentemente, a SEC suspendeu a obrigatoriedade da contabilização a valor justo para títulos de alguns emissores e para algumas classes de ativos financeiros. A SEC também ficou encarregada de, em três meses, preparar para o Congresso Norte-americano um levantamento sobre o impacto do valor 
justo sobre as instituições financeiras, analisando, inclusive, se as regras deveriam ser modificadas.

O GNAIE (2008, p. 1-3) acredita que a aplicação da contabilidade a valor justo em mercados inativos, ilíquidos e desordenados para produtos de crédito estruturados serviu como combustível para a crise de crédito mundial. Em carta-comentário ao FASB, o GNAIE disse que a organização não acredita que a crise global foi causada pela contabilidade a valor justo, mas que uma mensuração não confiável e pouco transparente serviu como um poderoso acelerador. A solução proposta pela entidade foi migrar da mensuração a valor justo para um paradigma de custo amortizado e perda incorrida, mas apenas em situações onde os mercados não são ativos, líquidos ou ordenados.

Em outubro de 2008, o FASB e o IASB divulgaram nota conjunta para anunciar a criação de um grupo consultivo, formado por especialistas e investidores. De acordo com Yokoi (2008, p. 15), ao assistir à flexibilização de regras, os investidores entenderam que as autoridades estariam abrindo mão também do conceito de valor justo, mas o fato é que marcar ao valor de mercado é apenas a forma mais tradicional de se chegar ao valor justo.

Sobre a SFAS 157, faz-se necessário um esclarecimento: O princípio de marcar a mercado para reproduzir o valor justo vale apenas quando os preços de negociação são considerados eficientes. Negócios feitos sob estresse, portanto, não refletiriam o valor justo de um ativo.

Quando não há liquidez, podem ser usadas alternativas para se chegar a ele, como a referência de transações envolvendo ativos com características semelhantes, a projeção de fluxo de caixa e modelos matemáticos.

Yokoi (2008, p. 16) conta que Pedro Malan, em Seminário promovido pelo CPC, em São Paulo, disse que "culpar o valor justo é culpar o mensageiro". Em tempos de crise, contabilizar ativos e passivos a preços de mercado significa reconhecer perdas significativas, mas o critério contábil não é responsável por tais prejuízos.

Para Carvalho (2009), o fair value bem calculado é o fluxo de caixa de amanhã. A migração para um novo paradigma será um enorme desafio, um salto no escuro, no sentido de ser um modelo não testado. Desafio que deve ser enfrentado, pois o modelo antigo não serve mais. O custo histórico, se praticado ainda hoje, faria com que a crise atual fosse percebida, em um tamanho muito maior, daqui a três ou quatro anos. 
Segundo o Professor Nelson Carvalho, na matéria de Yokoi (2008, p. 16), “o que os organismos fizeram foi interpretar o que já estava na norma. O conceito de fair value afasta a ideia de que os preços de liquidação sejam considerados justos". Para ele, além de não ser culpada pelo agravamento da crise, a contabilização pelo valor justo tem o mérito de ter trazido à tona as deficiências do crédito hipotecário americano. "Não fosse o valor justo, a crise só teria sido descoberta daqui a alguns anos, e em estágio muito pior".

Yokoi (2008, p. 16) acredita que o valor justo evidenciou a crise, mas que a crise também escancarou os problemas do valor justo. O primeiro problema é a fragilidade do conceito em situações de forte abalo do mercado financeiro, justamente quando é crucial ter uma avaliação correta de preços. O segundo ponto é a subjetividade. Imagine uma Instituição de Crédito Imobiliário que tinha um ativo de \$100 com vencimento no longo prazo. Hoje, se esse ativo fosse negociado, o valor da transação não passaria de $\$ 5$, de forma que, se contabilizado por $\$$ 100 , este ativo estaria superavaliado, e se estivesse contabilizado por $\$ 5$, estaria subavaliado. O grande desafio é determinar qual valor no intervalo entre \$ 5 e \$ 100 representa o valor justo.

Young (2008, p. 4-5) informa que as grandes instituições financeiras passaram a aplicar a SFAS 157 antes mesmo da sua obrigatoriedade, porém, quando o mercado ativo das CDO deixou de existir, elas foram obrigadas a divulgar seus números sob o Nível 3 da hierarquia fair value, dependente de expectativas subjetivas. Evidentemente, muitos investidores não gostaram da informação que receberam, representada por um valor numérico, que normalmente sugere uma precisão que não seria verdadeira naquele momento. Muitas demonstrações contábeis foram ajustadas subsequentemente, algumas porque seus modelos precisavam ser ajustados e outras porque as premissas precisavam ser atualizadas, o que alimentou o repertório dos críticos da contabilidade a valor justo. Maria Helena Petterson, sócia da área de auditoria da Ernst \& Young, acha que esse alto nível de subjetividade pode postergar o aparecimento de perdas. O professor Nelson Carvalho concorda que é preciso ter argumentos convincentes para afirmar que um ativo vale $\mathrm{x}$ ou y, e lembra que os próprios usuários da informação contábil devem exigir explicações sobre como um item foi avaliado, de acordo com matéria de Yokoi (2008, p. 16).

Em uma análise atenta, de acordo com Véron (2008, p. 1), percebe-se que não há apenas uma crítica à contabilidade a valor justo, mas duas, centradas respectivamente na falta de liquidez e na pró-ciclicalidade. Em relação à falta de liquidez, nota-se que as condições de mercado de muitos instrumentos financeiros complexos, desde agosto de 2007, foram reduzidas 
anormalmente pela evaporação da liquidez, e pode não ter mantido relação com o valor definido como o potencial para geração de fluxos de caixa futuros. Indicações de preços para instrumentos que possam ser considerados "similares", de acordo com o nível 2 da hierarquia do valor justo, como o índice ABX, publicado pela empresa Markit, vêm sofrendo quedas consideráveis desde agosto de 2007, e os volumes de negociação implícitos nesses índices têm sido limitados. Este fato muitas vezes obriga os bancos a registrar uma queda nos seus valores não justificada por fundamentos econômicos. Para manter seus índices de solvência, são forçados a aumentar o capital sob condições deprimidas de valorização, em prejuizo dos acionistas atuais.

A pró-ciclicalidade é uma crítica ainda mais abrangente, segundo Véron (2008, p. 1-2). De acordo com ela, a ideia de que preços de mercado, quando observáveis, são a melhor indicação do valor justo, pode transmitir uma aparente robustez no balanço dos bancos, no momento de pico de um ciclo econômico, e redução catastrófica desta robustez quando este ciclo entrar em depressão. Assim, os padrões de contabilidade poderiam ser culpados pela acentuação de altas e baixas. Essas dificuldades são reais, porém, a conclusão que se chega é que alterar os atuais padrões de forma a restringir o escopo da contabilidade a valor justo não seria um ato convincente, pois não há alternativas críveis, que preencham os requisitos de relevância, confiabilidade, comparabilidade e compreensibilidade. Além disso, uma restrição ao uso do valor justo poderia aumentar a confusão entre preocupações contábeis e conservadorismo, que tratam de objetivos distintos e, portanto, deveriam ser cuidadosamente distintos.

Uma opção proposta para substituir a referência aos "instrumentos similares" seria o uso de precificação por modelos internos, ou market-to-model, o que hoje é permitido somente quando não há cotações ou preços de mercado para o instrumento avaliado ou instrumentos similares. Véron (2008, p. 2), afirma que os modelos são largamente utilizados e podem atingir maior grau de transparência se lastreados em informação detalhada sobre os instrumentos avaliados e premissas. A maioria dos investidores vê a marcação por modelos como último recurso, preferindo a marcação a mercado sempre que houver alguma referência.

Véron (2008, p. 3) recorda que, em um comentário publicado em 3 de abril de 2008 no Financial Times, três membros do European Reporting Advisory Group (EFRAG) propuseram um mecanismo para suavizar os preços de mercado por um período de seis meses a um ano, o qual serviria como padrão de medida para redução do valor de ativos financeiros. Essas alternativas, em geral, reduzem a informação disponível aos usuários externos, e em muitos casos 
disponibilizam ferramentas de gerenciamento de resultados e distorcem os relatórios financeiros de uma maneira que a contabilidade a valor justo não permite. Assim, se essas propostas fossem adotadas, é possível que fossem exigidos maiores prêmios por riscos e que o mercado saísse enfraquecido. Este efeito foi observado de maneira espetacular no Japão da década de 1990, quando o ministro de finanças permitiu que os bancos não depreciassem seus ativos, que haviam sofrido queda de valor resultante de uma depressão do mercado. Como o mercado não sabia onde se concentravam as perdas, todos os bancos japoneses sofreram os efeitos da falta de transparência, não só aqueles que realmente experimentaram as perdas.

Adicionalmente, Véron (2008, p. 3) sugere que o medo associado à superavaliação de perdas decorrentes da contabilidade a valor justo não se fundamenta. No primeiro trimestre de 2008, o Banco UBS divulgou perdas da ordem de USD 19 bilhões. No dia $1^{\circ}$ de abril de 2008 , suas ações subiram aproximadamente $15 \%$ em comparação com o dia anterior, valores que se sustentaram nos dias de negociação subsequentes. Em contraste, há episódios em que o mercado perdeu completamente a confiança em uma instituição financeira, como aconteceu com o Bear Stearns a partir de 13 de março, quando a preocupação dos investidores não estava associada com evidenciação contábil, mas com liquidez e solvência da instituição.

Por fim, Véron (2008, p. 5) lembra que a informação contábil requerida pelos padrões contábeis é apenas parte da informação financeira fornecida pelas instituições financeiras. Transparência a respeito de riscos assumidos, por exemplo, precisam ser melhoradas, em particular à luz das lições da crise financeira e da relativa redução de credibilidade dos ratings de crédito.

\subsubsection{Prevenção}

Na opinião de Taleb (2007, p. 23), o mundo é dominado pelo extremo, pelo desconhecido e pelo improvável. Para o autor, um evento raro equivale à incerteza. Ele cita duas formas de abordar fenômenos:

- Excluindo eventos extraordinários e concentrando-se no normal;

- Considerando primeiro os extremos, para depois compreender um fenômeno.

Para Taleb, a curva estatística normal, que ele chama de curva em formato de sino, ignora grandes desvios, sendo incapaz de lidar com eles. Ele acredita que a abordagem estatística tradicional faz com que as análises sejam ofuscadas por médias e medianas. 
Taleb (2007, p. 73) questiona "como sabemos que o que observamos a partir de certos objetos e eventos é suficiente para que tenhamos a capacidade de descobrir suas outras propriedades?" Essas são armadilhas embutidas em qualquer tipo de conhecimento adquirido por meio da observação.

Soros (2008, p. 27-35) alude a um novo paradigma em economia, referindo-se à teoria da reflexividade, que diz que a compreensão do mundo pelo homem é imperfeita, já que o próprio pesquisador faz parte do mundo que tenta compreender. Assim, o pesquisador interage com a realidade de duas maneiras: de um lado, tentando compreender o mundo em que vive (função cognitiva), e de outro, tentando causar um impacto no mundo e transformar sua própria condição (função manipulativa). Quando essas duas funções operam simultaneamente, podem interferir uma na outra.

Os participantes são incapazes de basear suas decisões no conhecimento, pois devem lidar não só com os fatos do presente e do passado, mas também com o impacto das intenções e expectativas sobre o futuro, o que cria uma relação de mão dupla entre o pensamento dos participantes e a situação da qual eles participam.

Exemplo: Mercado de ações

Pessoas vendem e compram ações baseando-se nas expectativas sobre os preços futuros das ações, mas esses preços dependem das expectativas dos investidores. Expectativas não podem ser consideradas conhecimento. Se falta conhecimento, os participantes têm de agregar algo de avaliação ou propensão ao processo de tomada de decisões. Com isso, o resultado tende a divergir das expectativas.

\subsubsection{Report and Recommendations Pursuant to Section 133 of the Emergency Economic Stabilization Act}

Em 3 de outubro de 2008, o Ato de Estabilização Econômica Emergencial de 2008 ("EESA" ou o "Ato") foi aprovado nos Estados Unidos. A seção 133 do Ato designou a SEC para conduzir, em conjunto com o Fed e a Secretaria do Tesouro, um estudo sobre os padrões de contabilidade baseados na marcação a mercado, providos pelo FASB através da SFAS 157. Conforme mencionado em outras seções deste trabalho, a SFAS 157 não requer contabilizações por valor de mercado ou valor justo, pois tal requerimento está contido em outras normas, 
enquanto a SFAS 157 apenas estabelece uma base conceitual para mensuração ao valor justo e expande requerimentos de divulgação. Entendendo isso, o Staff da SEC (Staff) efetuou a análise da contabilidade a valor justo de uma maneira mais ampla, incluindo a marcação a mercado e a SFAS 157, reportando seu estudo através do Report and Recommendations Pursuant to Section 133 of the Emergency Economic Stabilization Act.

SEC (2008, p. 1) aponta que os participantes de mercado indicaram que as informações a respeito do valor justo são vitais em tempos de nervosismo no mercado, e a suspensão dessas informações poderia enfraquecer a confiança do investidor e resultar em maiores instabilidades. Esses participantes acreditam que as raízes da crise têm relação com decisões erradas na concessão de empréstimos e no gerenciamento de riscos, combinadas com falhas nas práticas de regulação e supervisão, em vez de práticas contábeis. Culpar a contabilidade a valor justo, na visão desses parcipantes, é como "matar o mensageiro" e ocultar dos provedores de capitais a verdadeira condição econômica de uma instituição. No entanto, foram apontados ajustes no cálculo do capital regulatório.

Como o debate a respeito da contabilidade a valor justo se intensificou em meados de setembro de 2008, o FASB publicou alguns documentos a respeito da mensuração pelo valor justo na hipótese de não haver um mercado ativo.

Conforme exigido pelo Ato, SEC (2008, p. 1-204) endereçou seis assuntos-chave em seções separadas.

1. Efeitos dos padrões baseados na contabilidade a valor justo nos balanços das Instituições Financeiras. O Staff observou que os critérios do valor justo foram aplicados na mensuração da menor parte dos ativos (45\%) e passivos (15\%) incluídos nos balanços das instituições financeiras. O percentual dos ativos para os quais mudanças no valor justo afetaram os resultados foi significativamente baixo (25\%), refletindo as flutuações de mercado nos derivativos e ativos para negociação de curto prazo. No entanto, para as mesmas instituições, o Staff observou que a mensuração pelo valor justo afetou significativamente as demonstrações de resultado.

2. Impacto da contabilidade a valor justo na insolvência de bancos em 2008. O Staff observou que a contabilidade a valor justo aparentemente não desempenhou nenhum papel decisivo nas insolvências de bancos durante o ano de 2008. Alguns bancos 
falidos apresentaram grandes perdas decorrentes da mensuração ao valor justo, porém, nada indica que o critério de mensuração tem alguma relação com a bancarrota.

3. Impacto da contabilidade a valor justo na qualidade da informação financeira disponível aos investidores. Foi concluído que os investidores geralmente apoiam a contabilidade a valor justo como provedora de relatórios financeiros mais transparentes. Alguns investidores apontaram a necessidade de melhorias, particularmente na divulgação de informações em tempos de crise e na mensuração de passivos.

4. Processos do FASB no desenvolvimento de padrões contábeis.

5. Alternativas ao padrão contábil baseado no valor justo.

6. Conveniência e praticabilidade de modificações na contabilidade a valor justo.

O Staff da SEC (2008, p. 40) considerou que uma das áreas menos desenvolvidas na estrutura conceitual básica da contabilidade é a da mensuração, para a qual não há nenhum estudo de vantagens e desvantagens de cada uma das bases de mensuração ou mesmo um guia para ajudar na escolha de uma das bases de mensuração listadas. Em um estudo de 2003 sobre uma contabilidade baseada em princípios, entre outras coisas, é destacada a existência de uma estrutura conceitual básica consistente e bem desenvolvida.

O Staff da SEC (2008, pg. 97) concluiu que a contabilidade não foi uma das causas primárias da falência dos bancos americanos no ano de 2008. Para a maioria destes, a contabilidade a valor justo foi aplicada de forma limitada, e as perdas decorrentes do valor justo não tiveram impacto significante no capital desses bancos. O estudo da SEC também concluiu que, quando a contabilidade e os relatórios financeiros relatam uma perda, não estão causando o problema, mas provendo uma informação acerca deste. O decréscimo do capital regulatório desses bancos foi causado primeiramente pelo reconhecimento de perdas de crédito, e não pelo reconhecimento das variações no valor justo dos ativos financeiros.

A conclusão do Report and Recommendations Pursuant to Section 133 of the Emergency Economic Stabilization Act da SEC (2008, p. 200-209) diz que a suspensão da SFAS 157 não reduziria o uso da contabilidade a valor justo, já que o conceito de valor justo está espalhado em diversos pronunciamentos do FASB. Essa suspensão apenas reduziria a comparabilidade e a consistência desse tipo de mensuração. Em vez de suspender a SFAS 157, o Ato concluiu que 
deveria melhorar este guia para o caso de mercados ilíquidos ou inativos, além de aumentar o disclosure relativo ao efeito do valor justo nos relatórios financeiros.

Os desafios enfrentados pela contabilidade a valor justo, de acordo com SEC (2008, p. 179), geralmente passam pelas quatro preocupações seguintes:

1. O valor justo é potencialmente menos confiável na ausência de cotações de mercado, resultando na redução da comparabilidade e da confiabilidade das demonstrações financeiras.

2. A contabilidade a valor justo aumenta a volatilidade dos resultados reportados.

3. Existe inconsistência entre medidas de valor corrente (especialmente quando se fala em valores de saída) quando é esperado que a companhia opere em situação de continuidade.

4. O valor justo subavalia o "verdadeiro valor econômico" de um instrumento financeiro quando os mercados estao deprimidos, levando a preocupações com pro-ciclicalidade.

Segundo o Federal Deposit Insurance Corporation (FIDC), 22 bancos americanos se tornaram insolventes durante o ano de 2008, conforme a Figura 26, onde se pode ver a localização de cada um dos bancos, seu principal regulador na esfera Federal, a data em que foi decretada a falência e o total de Ativos, em dólares americanos, entre outras informações.

Para a maioria dos bancos da amostra, os ativos mais significantes eram os empréstimos mantidos para investimentos (Loans HFI), os quais não estavam.contabilizados pelo valor justo, mas pelo método do custo amortizado, com reconhecimento somente de perdas incorridas. Essas perdas são reconhecidas, segundo SEC (2008, p. 104), quando se torna provável que o mutuário não irá cumprir com os pagamentos contratuais.

Quando espera-se que um empréstimo seja quitado exclusivamente por meio de suas garantias, a perda de crédito deve se basear no valor justo desta garantia, de acordo com SEC (2008, p. 104). Muitos bancos tendem a manter seus portfolios na categoria AFS (Disponível para a venda), sob as USGAAP, na qual perdas no valor justo não realizadas só impactam os resultados quando decorrerem de perdas permanentes.

SEC (2008, p. 104) informa que, quanto mais complexas as operações financeiras de uma entidade, maior a tendência de utilizar a mensuração pelo valor justo. Por exemplo, bancos que originam ou compram carteiras de empréstimos para vender geralmente reportam seus ativos pelo 
valor justo. Esses bancos que originam e vendem um alto volume de ativos geralmente contabilizam os mesmos como HFS nos seus balanços. Sob as USGAAP, HFS Loans em geral são registrados pelo menor valor entre custo e valor justo ou pelo valor justo por meio de resultados.

\begin{tabular}{|c|c|c|c|c|c|c|c|c|}
\hline & Bank Name & Location & $\begin{array}{l}\text { Primary } \\
\text { Federal } \\
\text { Regulator }\end{array}$ & $\begin{array}{l}\text { Date of } \\
\text { Failure }\end{array}$ & $\begin{array}{l}\text { Total Assets } \\
\text { (in U.S. } \\
\text { Dollars)* }\end{array}$ & $\begin{array}{l}\text { Last Reported } \\
\text { Capital Status }\end{array}$ & $\begin{array}{l}\text { Estimated } \\
\text { Cost to FDIC } \\
\text { Insurance } \\
\text { Fund }\end{array}$ & $\begin{array}{c}\text { Source of Last } \\
\text { Reported Capital } \\
\text { Status }\end{array}$ \\
\hline 1 & $\begin{array}{l}\text { Douglass National } \\
\text { Bank }\end{array}$ & Kansas City, MO & $\mathrm{OCC}$ & $1 / 25 / 2008$ & $<\$ 1$ billion & $\begin{array}{l}\text { Significantly } \\
\text { Undercapitalized }\end{array}$ & $\$ 0.006$ billion & $\begin{array}{l}\text { December 31, } 2007 \\
\text { Call Report }\end{array}$ \\
\hline 2 & Hume Bank & Hume, MO & FDIC & $3 / 07 / 2008$ & $<\$ 1$ billion & Well Capitalized & $\begin{array}{l}\text { No estimate } \\
\text { provided }\end{array}$ & $\begin{array}{l}\text { December 31, } 2007 \\
\text { Call Report }\end{array}$ \\
\hline 3 & ANB Financial & Bentonville, AR & $\mathrm{OCC}$ & $5 / 09 / 2008$ & $<\$ 3$ billion & $\begin{array}{l}\text { Critically } \\
\text { Undercapitalized }\end{array}$ & $\$ 0.214$ billion & $\begin{array}{l}\text { March 31, } 2008 \text { Call } \\
\text { Report }\end{array}$ \\
\hline 4 & First Integrity Bank & Staples, MN & $\mathrm{OCC}$ & $5 / 30 / 2008$ & $<\$ 1$ billion & $\begin{array}{l}\text { Critically } \\
\text { Undercapitalized }\end{array}$ & $\$ 0.002$ billion & $\begin{array}{l}\text { March 31, } 2008 \text { Call } \\
\text { Report }\end{array}$ \\
\hline 5 & IndyMac Bank & Pasadena, CA & OTS & $7 / 11 / 2008$ & $<\$ 33$ billion & $\begin{array}{l}\text { Significantly } \\
\text { Undercapitalized }\end{array}$ & $\$ 4$ to $\$ 8$ billion & $\begin{array}{l}\text { June 30, } 2008 \text { Thrift } \\
\text { Financial Report }\end{array}$ \\
\hline 6 & First Heritage Bank & $\begin{array}{l}\text { Newport Beach, } \\
\text { CA }\end{array}$ & $\mathrm{OCC}$ & $7 / 25 / 2008$ & $<\$ 1$ billion & $\begin{array}{l}\text { Critically } \\
\text { Undercapitalized }\end{array}$ & $* 8$ & $\begin{array}{l}\text { July } 25,2008 \text { press } \\
\text { release by the OCC } \\
\text { (NR 2008-88) }\end{array}$ \\
\hline 7 & $\begin{array}{l}\text { FN Bank of } \\
\text { Nevada }\end{array}$ & Reno, NV & $\mathrm{OCC}$ & $7 / 25 / 2008$ & $<\$ 4$ billion & Undercapitalized & $\$ 0.862$ billion ${ }^{* 8}$ & $\begin{array}{l}\text { June } 30,2008 \text { Call } \\
\text { Report }\end{array}$ \\
\hline 8 & First Priority Bank & Bradenton, FL & FDIC & $8 / 01 / 2008$ & $<\$ 1$ billion & $\begin{array}{l}\text { Critically } \\
\text { Undercapitalized }\end{array}$ & $\$ 0.072$ billion & $\begin{array}{l}\text { June } 30,2008 \text { Call } \\
\text { Report }\end{array}$ \\
\hline 9 & $\begin{array}{l}\text { Columbian Bank } \\
\text { and Trust }\end{array}$ & Topeka, KS & FDIC & $8 / 22 / 2008$ & $<\$ 1$ billion & $\begin{array}{l}\text { Adequately } \\
\text { Capitalized }\end{array}$ & $\$ 0.06$ billion & $\begin{array}{l}\text { June } 30,2008 \text { Call } \\
\text { Report }\end{array}$ \\
\hline 10 & Integrity Bank & Alpharetta, GA & FDIC & $8 / 29 / 2008$ & $<\$ 2$ billion & Undercapitalized & $\begin{array}{l}\$ 0.25 \text { to } \$ 0.35 \\
\text { billion }\end{array}$ & $\begin{array}{l}\text { June } 30,2008 \text { Call } \\
\text { Report }\end{array}$ \\
\hline 11 & Silver State Bank & Henderson, NV & FDIC & $9 / 05 / 2008$ & $<\$ 3$ billion & $\begin{array}{l}\text { Adequately } \\
\text { Capitalized }\end{array}$ & $\begin{array}{l}\$ 0.45 \text { to } \$ 0.55 \\
\text { billion }\end{array}$ & $\begin{array}{l}\text { June } 30,2008 \text { Call } \\
\text { Report }\end{array}$ \\
\hline 12 & Ameribank & Northfork, WV & OTS & $9 / 19 / 2008$ & $<\$ 1$ billion & $\begin{array}{l}\text { Critically } \\
\text { Undercapitalized }\end{array}$ & $\$ 0.042$ billion & $\begin{array}{l}\text { September } 19,2008 \\
\text { press release by the } \\
\text { OTS (OTS 08-045) }\end{array}$ \\
\hline 13 & $\begin{array}{l}\text { Washington } \\
\text { Mutual Bank }\end{array}$ & Henderson, NV & OTS & $9 / 25 / 2008$ & $<\$ 308$ billion & Well Capitalized & $\$ 0$ & $\begin{array}{l}\text { June 30, } 2008 \text { Thrift } \\
\text { Financial Report }\end{array}$ \\
\hline 14 & Main Street Bank & Northville, MI & FDIC & $10 / 10 / 2008$ & $<\$ 1$ billion & $\begin{array}{l}\text { Significantly } \\
\text { Undercapitalized }\end{array}$ & $\begin{array}{l}\text { \$0.033 to } \\
\$ 0.039 \text { billion }\end{array}$ & $\begin{array}{l}\text { June 30, } 2008 \text { Call } \\
\text { Report }\end{array}$ \\
\hline 15 & Meridian Bank & Eldred, II & FDIC & $10 / 10 / 2008$ & $<\$ 1$ billion & $\begin{array}{l}\text { Critically } \\
\text { Undercapitalized }\end{array}$ & $\begin{array}{l}\$ 0.013 \text { to } \$ 0.015 \\
\text { billion }\end{array}$ & $\begin{array}{l}\text { September } 30,2008 \\
\text { Call Report }\end{array}$ \\
\hline 16 & $\begin{array}{l}\text { Alpha Bank \& } \\
\text { Trust }\end{array}$ & Alpharetta, GA & FDIC & $10 / 24 / 2008$ & $<\$ 1$ billion & $\begin{array}{l}\text { Critically } \\
\text { Undercapitalized }\end{array}$ & $\$ 0.158$ billion & $\begin{array}{l}\text { September } 30,2008 \\
\text { Call Report }\end{array}$ \\
\hline 17 & Freedom Bank & Bradenton, FL & FDIC & $10 / 31 / 2008$ & $<\$ 1$ billion & $\begin{array}{l}\text { Significantly } \\
\text { Undercapitalized }\end{array}$ & $\begin{array}{l}\$ 0.08 \text { to } \$ 0.104 \\
\text { billion }\end{array}$ & $\begin{array}{l}\text { September } 30,2008 \\
\text { Call Report }\end{array}$ \\
\hline 18 & Franklin Bank & Houston, TX & FDIC & $11 / 07 / 2008$ & $<\$ 6$ billion & $\begin{array}{l}\text { Significantly } \\
\text { Undercapitalized }\end{array}$ & $\begin{array}{l}\$ 1.4 \text { to } \$ 1.6 \\
\text { billion }\end{array}$ & $\begin{array}{l}\text { September } 30,2008 \\
\text { Call Report }\end{array}$ \\
\hline 19 & $\begin{array}{l}\text { Security Pacific } \\
\text { Bank }\end{array}$ & Los Angeles, CA & FDIC & $11 / 07 / 2008$ & $<\$ 1$ billion & $\begin{array}{l}\text { Significantly } \\
\text { Undercapitalized }\end{array}$ & $\$ 0.21$ billion & $\begin{array}{l}\text { September 30,2008 } \\
\text { Call Report }\end{array}$ \\
\hline 20 & $\begin{array}{l}\text { The Community } \\
\text { Bank }\end{array}$ & Loganville, GA & FDIC & $11 / 21 / 2008$ & $<\$ 1$ billion & $\begin{array}{l}\text { Significantly } \\
\text { Undercapitalized }\end{array}$ & $\begin{array}{l}\$ 0.2 \text { to } \$ 0.240 \\
\text { billion }\end{array}$ & $\begin{array}{l}\text { September } 30,2008 \\
\text { Call Report }\end{array}$ \\
\hline 21 & $\begin{array}{l}\text { Downey Savings } \\
\text { and Loan }\end{array}$ & $\begin{array}{l}\text { Newport Beach, } \\
\mathrm{CA}\end{array}$ & OTS & $11 / 21 / 2008$ & $<\$ 13$ billion & Well Capitalized & $\$ 1.4$ billion & $\begin{array}{l}\text { September } 30,2008 \\
\text { Thrift Financial } \\
\text { Report }\end{array}$ \\
\hline 22 & $\begin{array}{l}\text { PFF Bank and } \\
\text { Trust }\end{array}$ & Pomona, CA & OTS & $11 / 21 / 2008$ & $<\$ 4$ billion & Undercapitalized & S0.7 billion & $\begin{array}{l}\text { September } 30,2008 \\
\text { Thrift Financial } \\
\text { Report }\end{array}$ \\
\hline
\end{tabular}

"As reported in the press release issued by the FDIC at the time of the instinution's closure
* FDIC bas estimated a combined cost to the FDIC insuracce fund of $\$ 0.862$ billion for First Heritage Bank of Newport Beach and FN Bank of Nevada

Figura 26: Bancos americanos falidos em 2008 - SEC (2008, p. 102-103)

As próximas quatro figuras (27 a 30) mostram composições de ativos e passivos dos bancos falidos em 2008, com total de ativos inferior a US\$ 1 Bilhão. A Figura 27, abaixo, 
ilustra a significância dos empréstimos mensurados pelo custo amortizado em relação ao total de ativos:

\begin{tabular}{|c|c|c|c|}
\hline Period Ended & $\begin{array}{c}\text { Total } \\
\text { Assets }{ }^{*}\end{array}$ & $\begin{array}{c}\text { Loans on a } \\
\text { Cost Basis }{ }^{* *}\end{array}$ & $\begin{array}{c}\text { Percent of } \\
\text { Total Assets }\end{array}$ \\
\hline \multicolumn{4}{|c|}{ (U.S. dollars in thousands) } \\
\hline June 30,2008 & $\$ 3,134,617$ & $\$ 2,598,764$ & $83 \%$ \\
\hline March 31, 2008 & $3,229,290$ & $2,689,863$ & $83 \%$ \\
\hline December 31, 2007 & $3,290,597$ & $2,761,350$ & $84 \%$ \\
\hline December 31, 2006 & $2,677,288$ & $2,259,851$ & $84 \%$ \\
\hline
\end{tabular}

Figura 27: Empréstimos contabilizados pelo custo amortizado

SEC (2008, P. 106)

Para esses bancos de pequeno porte, a Figura 28 mostra que os ativos e passivos mensurados pelo valor justo sob uma base recorrente não são significativos:

\begin{tabular}{l|c|c|c|c|}
\multicolumn{1}{|c}{} & $\begin{array}{c}\text { Trading } \\
\text { Assets }\end{array}$ & $\begin{array}{l}\text { Non-Trading } \\
\text { Financial } \\
\text { Assets }\end{array}$ & $\begin{array}{l}\text { Non- } \\
\text { Financial } \\
\text { Assets }\end{array}$ & Liabilities \\
\hline \multicolumn{5}{|c|}{ (As a percent of total assets) } \\
\hline June 30, 2008 & $0 \%$ & $0 \%$ & $0 \%$ & $0 \%$ \\
\hline March 31, 2008 & $0 \%$ & $0 \%$ & $0 \%$ & $0 \%$ \\
\hline December 31, 2007 & $0 \%$ & $0 \%$ & $0 \%$ & $0 \%$ \\
\hline December 31, 2006 & $0 \%$ & $0 \%$ & $0 \%$ & $0 \%$ \\
\hline
\end{tabular}

Figura 28: Ativos e passivos mensurados recorrentemente pelo valor justo SEC (2008, p. 106)

Para os investimentos em títulos, a Figura 29 demonstra que as perdas reconhecidas no resultado dos bancos estudados, decorrentes de variação no valor justo, referem-se a perdas por impairment.

\begin{tabular}{|l|r|r|r|c|}
\multicolumn{1}{c}{ Period Ended } & \multicolumn{1}{c}{ AFS* } & \multicolumn{1}{c}{ HTM $^{* *}$} & \multicolumn{1}{c}{ AFS } & HTM \\
\hline June 30, 2008 & $\$ 148,295$ & $\$ 2,990$ & $5 \%$ & $0 \%$ \\
\hline March 31, 2008 & 167,053 & 3,127 & $5 \%$ & $0 \%$ \\
\hline December 31, 2007 & 181,142 & 3,164 & $6 \%$ & $0 \%$ \\
\hline December 31, 2006 & 129,922 & 3,193 & $5 \%$ & $0 \%$
\end{tabular}

Figura 29: Investimentos em títulos (perdas no valor justo reconhecidas no resultado somente em casos de impairment) - SEC (2008, p. 107) 
A Figura 30 ilustra a insignificância dos ativos contabilizados pelo menor valor entre custo e valor justo. É possível notar que o percentual de Loans mantidos para venda (HFS) mensurados pelo menor entre o valor de custo e o valor justo é aproximadamente zero:

\begin{tabular}{|l|r|r|r|c|}
\multicolumn{1}{|c}{ Period Ended } & \multicolumn{1}{c}{ Loans HFS* } & $\begin{array}{c}\text { Other Real } \\
\text { Estate }\end{array}$ & Loans HFS & $\begin{array}{c}\text { Other Real } \\
\text { Estate }\end{array}$ \\
\hline June 30, 2008 & (U.S. dollars in thousands) & \multicolumn{1}{c|}{ Percent of total assets) } \\
\hline March 31, 2008 & 2,157 & 65,375 & $0 \%$ & $3 \%$ \\
\hline December 31, 2007 & 3,059 & 53,333 & $0 \%$ & $2 \%$ \\
\hline December 31, 2006 & 4,965 & 4,758 & $0 \%$ & $0 \%$ \\
\hline
\end{tabular}

Figura 30: Ativos contabilizados pelo menor valor entre custo e valor justo SEC (2008, p. 107)

Nos bancos falidos em 2008 com ativos entre 1 e 10 US\$ Bilhões, a mensuração pelo valor justo ainda é pequena, mas já se mostra um pouco maior que nos bancos de menor porte, conforme ilustram as figuras $31,32,33$ e 34 . Note que as figuras seguem o mesmo conceito das anteriores, figuras $27,28,29$ e 30 .

\begin{tabular}{|c|c|c|c|}
\hline Period Ended & $\begin{array}{c}\text { Total } \\
\text { Assets* } \\
\end{array}$ & $\begin{array}{c}\text { Loans on a } \\
\text { Cost Basis** }\end{array}$ & $\begin{array}{c}\text { Percent of } \\
\text { Total Assets } \\
\end{array}$ \\
\hline \multicolumn{4}{|c|}{ (U.S. dollars in thousands) } \\
\hline June 30,2008 & $\$ 16,406,725$ & $\$ 12,864,533$ & $78 \%$ \\
\hline March 31, 2008 & $19,666,923$ & $15,398,023$ & $78 \%$ \\
\hline December 31, 2007 & $19,652,563$ & $15,685,922$ & $80 \%$ \\
\hline December 31, 2006 & $18,731,349$ & $14,368,103$ & $77 \%$ \\
\hline
\end{tabular}

Figura 31: Empréstimos contabilizados pelo custo amortizado SEC (2008, P. 108)

\begin{tabular}{|c|c|c|c|c|}
\hline Period Ended & $\begin{array}{l}\text { Trading } \\
\text { Assets* }\end{array}$ & $\begin{array}{l}\text { Non-Trading } \\
\text { Financial } \\
\text { Assets } * *\end{array}$ & $\begin{array}{l}\text { Non- } \\
\text { Financial } \\
\text { Assets }= \pm \neq\end{array}$ & Liabilities" \\
\hline & \multicolumn{4}{|c|}{ (As a percent of total assets) } \\
\hline June 30,2008 & $0 \%$ & $1 \%$ & $0 \%$ & $0 \%$ \\
\hline March 31, 2008 & $0 \%$ & $1 \%$ & $0 \%$ & $0 \%$ \\
\hline December 31, 2007 & $0 \%$ & $0 \%$ & $0 \%$ & $0 \%$ \\
\hline December 31, 2006 & $0 \%$ & $0 \%$ & $0 \%$ & $0 \%$ \\
\hline
\end{tabular}

Figura 32: Ativos e passivos mensurados recorrentemente pelo valor justo SEC (2008, p. 108) 


\begin{tabular}{|r|r|r|r|r|}
\multicolumn{1}{c}{ Period Ended } & \multicolumn{1}{c}{ AFS* } & \multicolumn{1}{c}{ HTM $* *$} & \multicolumn{1}{c}{ HTM } \\
\hline June 30 3 , 2008 & $\$ 634,383$ & $\$ 340,354$ & $4 \%$ & $2 \%$ \\
\hline March 31, 2008 & 687,064 & 355,636 & $3 \%$ & $2 \%$ \\
\hline December 31, 2007 & 909,440 & 346,709 & $5 \%$ & $2 \%$ \\
\hline December 31, 2006 & 856,319 & 14,092 & $5 \%$ & $0 \%$ \\
\hline
\end{tabular}

Figura 33: Investimentos em títulos (perdas no valor justo reconhecidas no resultado somente em casos de impairment) - SEC (2008, p. 108)

Other

Other

Period Ended Loans HFS* Real Estate ${ }^{* *}$ Loans HFS Real Estate

\begin{tabular}{|r|r|r|r|r|}
\hline & \multicolumn{3}{|c}{ U.S. dollars in thousands) } & (Percent of total assets) \\
\hline June 30, 2008 & $\$ 195,535$ & $\$ 168,170$ & $1 \%$ & $1 \%$ \\
\hline March 31,2008 & 231,392 & 123,658 & $1 \%$ & $1 \%$ \\
\hline December 31,2007 & 327,299 & 86,524 & $2 \%$ & $0 \%$ \\
\hline December 31, 2006 & $1,954,882$ & 31,862 & $10 \%$ & $0 \%$ \\
\hline
\end{tabular}

Figura 34: Ativos contabilizados pelo menor valor entre custo e valor justo - SEC (2008, p. 109)

O estudo da SEC (2008, p. 118-125) mostra que a redução no capital dos bancos falidos em 2008 foi dirigida basicamente pelo aumento nas provisões para perdas de crédito, conforme ilustram as figuras 35 e 36, em primeira instância para bancos de pequeno e médio porte e, em seguida, para os bancos Washington Mutual, IndyMac e Downey Savings and Loan.

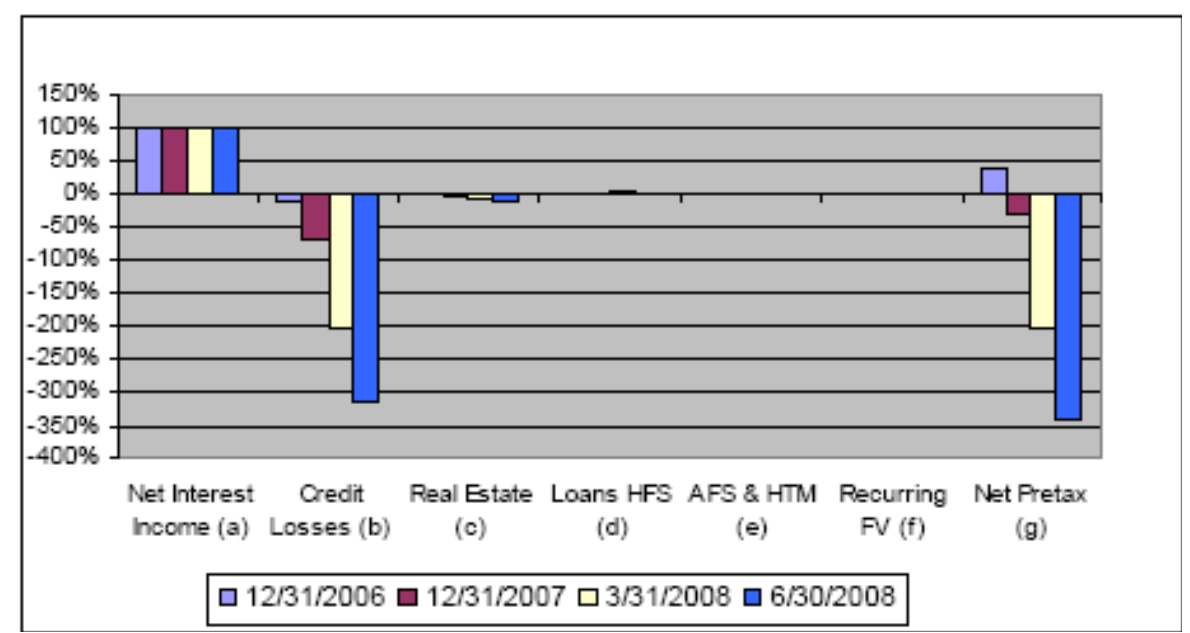

Figura 35: Resultado líquido, por holding categories, para bancos de menor porte - SEC (2008, p. 118) 


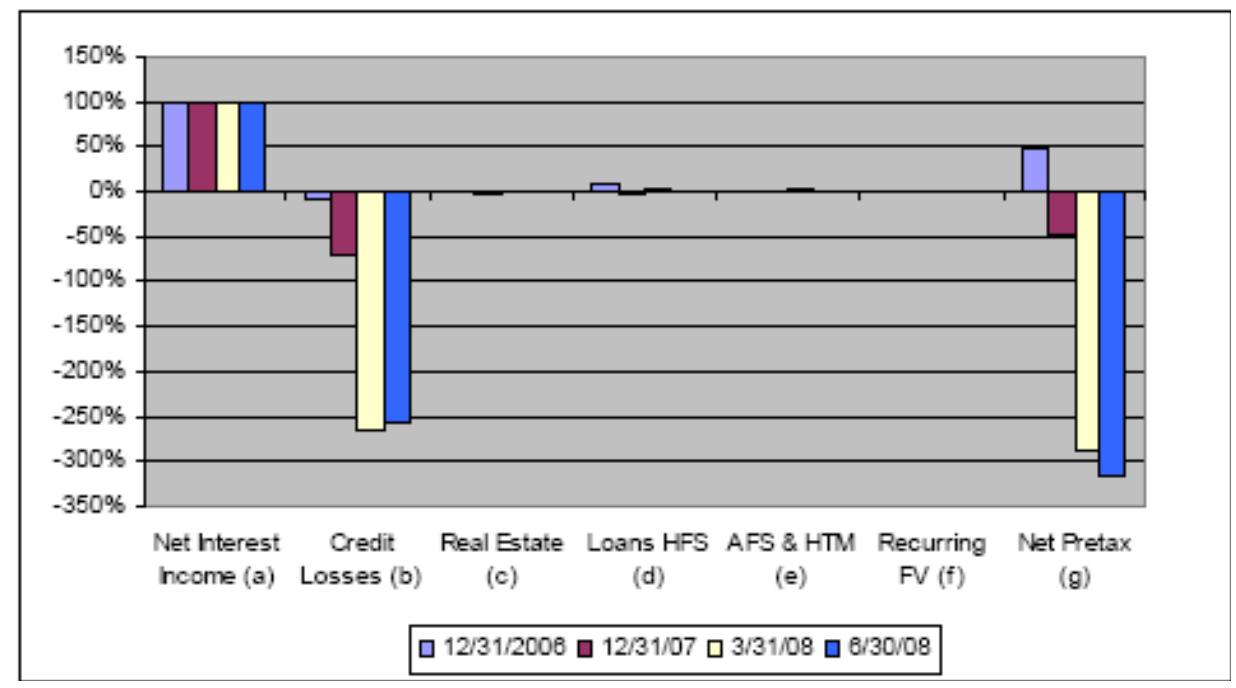

Figura 36: Resultado líquido, por holding categories, para bancos de médio porte SEC (2008, p. 119)

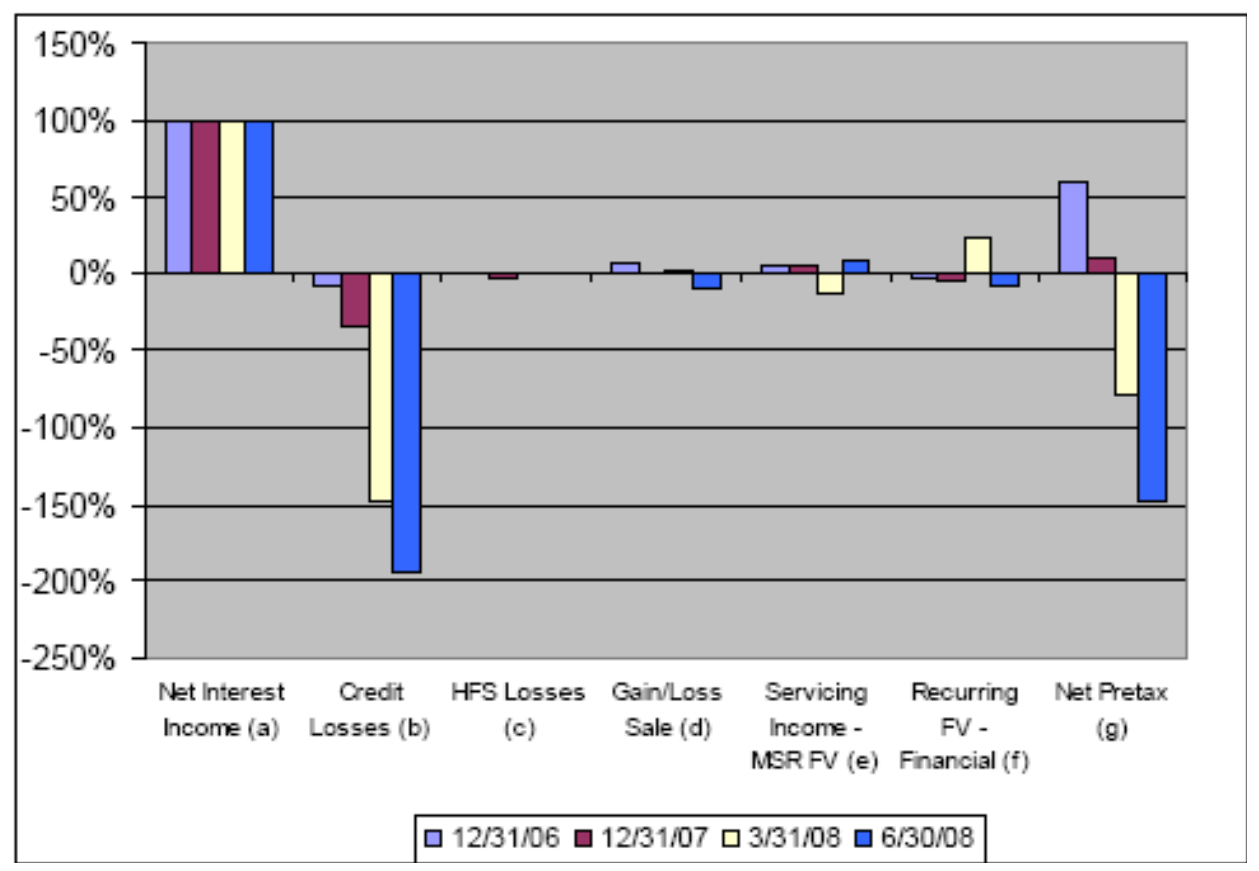

Figura 37: Resultado líquido, por holding categories, para o Banco Washington Mutual SEC (2008, p. 122) 


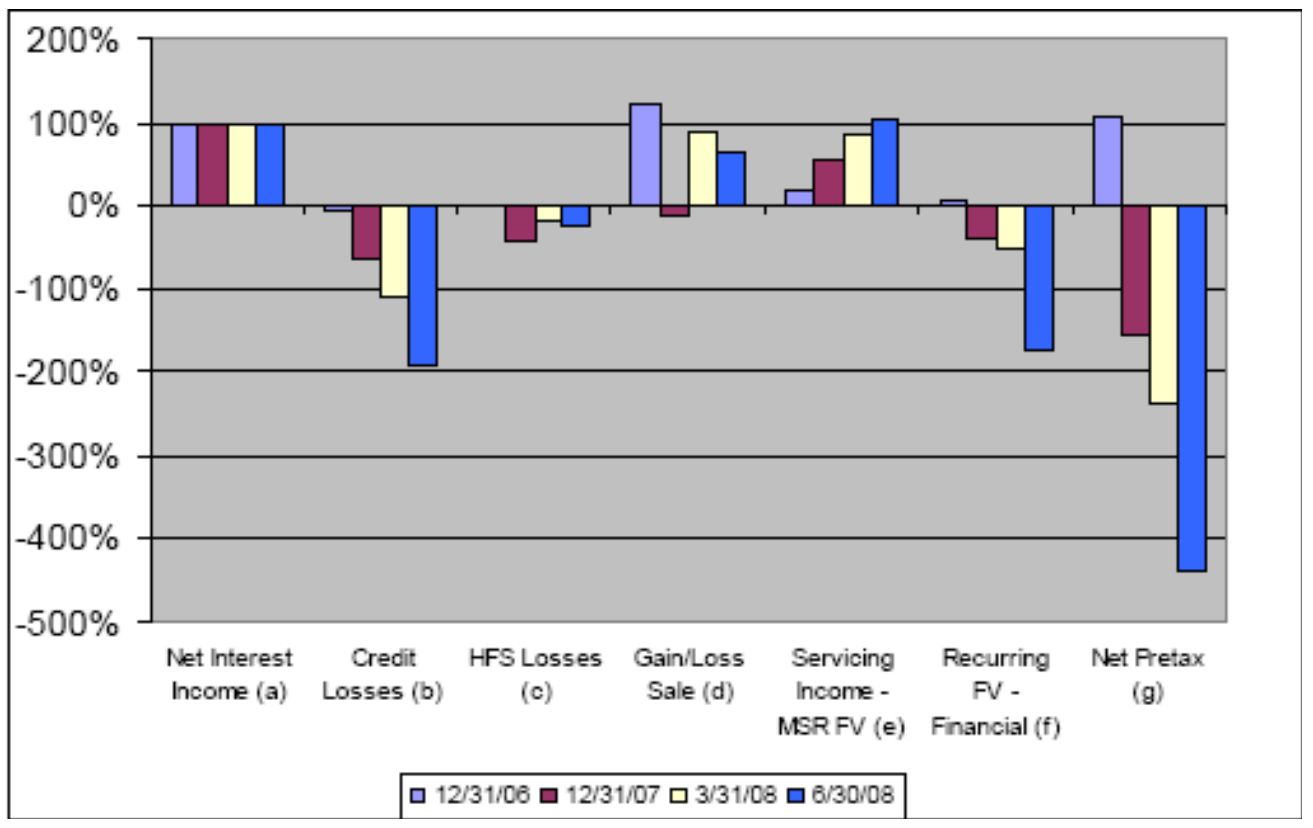

Figura 38: Resultado líquido, por holding categories, para o Banco IndyMac SEC (2008, p. 123)

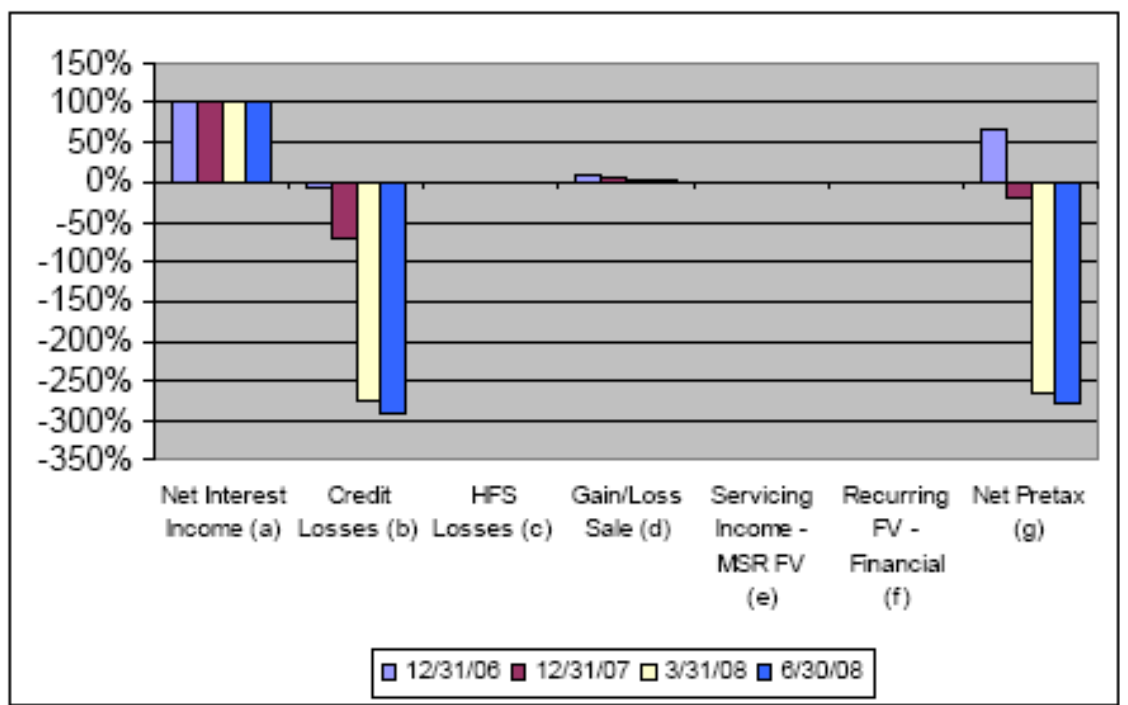

Figura 39: Resultado líquido, por holding categories, para o Downey Savings and Loan SEC (2008, p. 125)

O Bear Stearns sofreu uma rápida deterioção da sua liquidez em março de 2008, quando enfrentou uma corrida bancária semelhante a outras vistas em crises anteriores. Esta pressão, causada pela falta de confiança do mercado, precipitou preocupações a respeito dos ativos 
mantidos pelo Bear Stearns e das pobres decisões no gerenciamento de riscos, as quais permitiram que esses ativos fossem acumulados.

Em período próximo, o mercado soube dos desafios enfrentados pelo Lehman Brothers, que no segundo trimestre de 2008 divulgou uma concentração que foi chamada de "ativos legado". Esses ativos ilíquidos eram acumulados antes de futura securitização. No entanto, quando o mercado de securitizações parou, esses ativos, que o Lehman esperava manter por um curto período, tiveram de ser mantidos em seus balanços.

Até meados de dezembro de 2008, a SEC (2008, p. 139) recebeu cerca de 186 cartascomentário sobre a contabilidade a valor justo. Entre essas cartas, a do CFA Institute foi suportada pela opinião de cerca de 12.000 de seus membros, que mostrava que $79 \%$ daqueles eram contra a suspensão da contabilidade a valor justo, e $85 \%$ acreditavam que a suspensão da contabilidade a valor justo reduziria a confiança dos investidores no sistema bancário. A SEC (2008, p. 183) recebeu diversas cartas de investidores que não concordavam com a visão de que a contabilidade a valor justo seria pró-cíclica. Ao contrário, a pró-ciclicalidade estaria relacionada com os efeitos de mercado da desalavancagem dos bancos, e não com o critério contábil que relata esses efeitos. Mesmo entre aqueles que acreditam na pró-ciclicalidade da contabilidade a valor justo, alguns continuam a acreditar que a contabilidade a valor justo deveria ser mantida. Assim, em vez de suspender a contabilidade a valor justo, a ideia seria suplementar informações sobre esse tipo de mensuração com maior nível de evidenciação. 


\section{TRATAMENTO E ANÁLISE DE DADOS}

\subsection{Proceder metodológico}

O presente trabalho é desenvolvido de acordo com um método indutivo, que parte de opiniões individuais para estruturar uma opinião geral. Indução é um processo mental por intermédio do qual, partindo de dados particulares, suficientemente constatados, infere-se uma verdade geral ou universal, não contida nas partes examinadas. Portanto, o objetivo dos argumentos indutivos é levar a conclusões cujo conteúdo é mais amplo do que o das premissas nas quais se baseiam. Taleb $(2008$, p. 74) lembra que o aspecto mais preocupante da indução é que o aprendizado ocorre de trás para frente, e sugere, em sua obra, que generalizações realizadas sob o método indutivo são sempre arriscadas.

Após a revisão bibliográfica, foram realizadas entrevistas individuais com renomados especialistas em economia e/ou mercado financeiro. Entrevistas normalmente são realizadas para a determinação de opiniões sobre os fatos estudados. No caso deste trabalho, apesar de haver um roteiro previamente estabelecido, que preserva a característica de comparabilidade, trata-se de uma entrevista semiestruturada, que possibilita adaptações no roteiro, de acordo com os conhecimentos e interesses de cada entrevistado.

As entrevistas foram realizadas pessoalmente pelo próprio autor deste trabalho, sendo que cada uma destas foi gravada e arquivada eletronicamente, posteriormente transcrita, submetida à avaliação de cada entrevistado e, por fim, consolidada nesta obra.

No início de cada entrevista, o autor do trabalho explicou aos entrevistados as ideias e motivações da dissertação, garantiu privacidade das informações assinaladas nas questões de múltipla escolha, pediu permissão para gravação da questão aberta (primeiro tópico do roteiro) e autorização para a reprodução das suas teses sobre a crise.

\subsection{Amostra}

A amostra é intencional, não-probabilística, o que faz com que seus resultados não possam ser generalizados. 
Foram selecionados 13 profissionais com grande influência no mercado de capitais brasileiro, para que suas opiniões auxiliassem na composição das conclusões deste trabalho. Foram priorizados profissionais que ocuparam ou ocupam posições de liderança (presidência ou diretoria) no Banco Central do Brasil, Ministério da Fazenda e/ou CVM, e profissionais que ocupam posição de destaque no mercado financeiro.

As seguintes pessoas contribuíram para este trabalho com suas percepções e conhecimentos:

01. Marcos Eugênio da Silva

02. Hélio Nogueira da Cruz

03. Alkimar Moura

04. Gustavo Loyola

05. Clive Botelho

06. Roberto Padovani

07. Gustavo Franco

08. Ilan Goldfajn

09. Mailson da Nóbrega

10. Maria Helena Santana

11. Arminio Fraga

12. Teresa Grossi

13. Antônio Delfim Netto

No Apêndice A existe um curriculum resumido de cada um dos entrevistados.

\subsection{Procedimentos de testes}

$O$ roteiro de entrevista apresentado no Apêndice $B$ faz parte de uma pesquisa exploratória sobre a influência da contabilidade a valor justo na deflagração ou no agravamento da recente crise financeira mundial. Trata-se de uma entrevista semiestruturada que foi aplicada a um número bastante restrito de pessoas com notório conhecimento sobre ciências econômicas e/ou mercado de capitais. 
Para aproveitar ao máximo o conhecimento dos entrevistados, a primeira pergunta do roteiro é totalmente aberta, e o entrevistador pôde interagir com o entrevistado durante suas respostas, explorando melhor o conteúdo de seu discurso.

Em seguida, foi realizada uma pequena série de perguntas fechadas com foco na contabilidade a valor justo; porém, o entrevistador procurou estimular comentários do entrevistado, com o objetivo de enriquecer o trabalho.

O roteiro do Apêndice B teve contribuições dos Professores Nelson Carvalho, Gilberto Martins e Edgard Cornacchione, da FEA-USP, e foi testado em uma fase preliminar com o Professor Ricardo Rochman, da FGV-SP.

\subsection{Resultados}

$\mathrm{Na}$ fase preliminar às entrevistas, o Professor Ricardo Rochman enfatizou fatores como as inovações financeiras, regulação e supervisão deficientes, incentivos dos bancos para seus gestores, incentivos do Fed e do governo americano para o mercado. Um fator não inventariado neste roteiro e que também foi destacado por Rochman foi a importância da estrutura de governança corporativa. Rochman citou ainda a globalização e liberalização dos mercados como fatores que podem ter agravado a crise. Sobre a contabilidade, considera que a mesma não teve nenhum impacto na deflagração da crise. Acredita que a contabilidade a valor justo é pró-cíclica, mas necessária.

Questão 1: Em sua opinião, como a atual crise financeira foi preparada?

A informação transmitida por meio da Figura 40 resume em quadro os assuntos mencionados espontaneamente pelos entrevistados durante resposta à primeira questão. A figura mostra que, apesar da divergência de opiniões, alguns fatores foram mencionados por diversos entrevistados. Cada coluna representa as respostas de um dos entrevistados, enquanto a coluna "T" representa a soma de todas as colunas. Contudo, não é possível tirar conclusões pelo quadro antes de ler o extrato das entrevistas realizadas, material inserido logo após a figura. 


\begin{tabular}{|c|c|c|c|c|c|c|c|c|c|c|c|c|c|c|}
\hline \multirow{2}{*}{$\begin{array}{c}\text { Tópico mencionado espontaneamente durante resposta à } \\
\text { questão } 1\end{array}$} & \multicolumn{14}{|c|}{ ENTREVISTADO } \\
\hline & 1 & 2 & 3 & 4 & 5 & 6 & 7 & 8 & 9 & 10 & 11 & 12 & 13 & $\mathbf{T}$ \\
\hline Supervisão defíciente & r & & & & & & & & & & & r & & 2 \\
\hline $\begin{array}{l}\text { Fé nas previsões dos economistas que acreditavam que } \\
\text { os ciclos estavam "domados" }\end{array}$ & r & 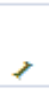 & & & & & & & & & z & & & 3 \\
\hline Fé nos modelos de risco & r & & & & & & & & r & & & & r & 3 \\
\hline Excesso de pessoas brilhantes no setor bancário & r & & & & & & & & z & & & & & 2 \\
\hline Alavancagem excessiva & r & & z & & r & z & & 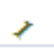 & z & & r & r & & 8 \\
\hline $\begin{array}{l}\text { Geração de poder aquisitivo fora da área regulada/ } \\
\text { Operações com setores menos regulados }\end{array}$ & & 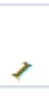 & & & 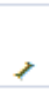 & & & & & & & & & 2 \\
\hline Instrumentos financeiros modernos & & r & r & $r$ & r & & r & r & r & & & & 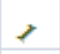 & 8 \\
\hline Politica monetária frouxa nos EUA & & & $\gamma$ & 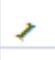 & r & r & & 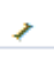 & $\gamma$ & r & & & $\gamma$ & 8 \\
\hline outros & & & r & r & r & & & & r & & r & & r & 6 \\
\hline Afrouxamente de politicas de crédito & & & r & & & & & & r & & & & & 2 \\
\hline Incentivos do governo americano & & & r & & & & & & r & & & r & r & 4 \\
\hline $\begin{array}{l}\text { Modelo de negócio dos bancos, com incentivos à criação } \\
\text { de operações }\end{array}$ & & & 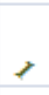 & & & & 2 & & & & & 2 & & 3 \\
\hline Agências de rating não cumpriram seu papel & & & r & & & & & r & & & r & & & 3 \\
\hline Menor aversão ao risco & & & & r & & & $r$ & r & r & $r$ & & & & 5 \\
\hline Globalização & & & & & r & & & & & & & & & 1 \\
\hline Regulação deficiente & & & & & $\gamma$ & r & & $r$ & & r & & 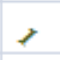 & & 5 \\
\hline Uso de veiculos off-balance sheet & & & & & r & & & & r & & r & r & r & 5 \\
\hline Descasamento de prazos de ativos e passivos & & & & & & & & & & & r & & & 1 \\
\hline $\begin{array}{l}\text { Reversão da politica monetária americana, com a alta dos } \\
\text { juros resultando em aumento da inadimplência }\end{array}$ & & & & & & r & & & & & & & & 1 \\
\hline Responsabilidade limitada dos gestores e acionistas & & & & & & & r & & & & & & & 1 \\
\hline Incentivos dos bancos para seus gestores & & & & & & & r & & 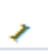 & & & r & & 3 \\
\hline Liquidação do Lehman Brothers & & & & & & & & & & & & $\gamma$ & r & 2 \\
\hline Politica de juros do Fed foram acertadas & 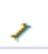 & & & & & & & & & & & & & 1 \\
\hline Valor justo não teve nenhuma culpa na crise & & z & & & & & & & & & & z & r & 3 \\
\hline $\begin{array}{l}\text { Informação contábil não tem força para gerar ou evitar } \\
\text { uma crise }\end{array}$ & & r & & & & & & & & & & & & 1 \\
\hline $\begin{array}{l}\text { solução rápida/ é informação fundamental para o } \\
\text { investidor }\end{array}$ & & & 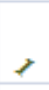 & & & & & & & & & & $r$ & 2 \\
\hline Politica monetária foi muito pouco relevante & & & & & & & $\gamma$ & & & & & & & 1 \\
\hline
\end{tabular}

Figura 40: Tópicos mencionados espontaneamente durante resposta à primeira questão

\section{Marcos Eugênio da Silva}

Segundo o Professor Marcos Eugênio da Silva, a atual crise é fundamentalmente uma crise de crédito. Sua história começa no mercado imobiliário americano e se espalha para outros 
mercados, transformando-se em uma crise generalizada. E, quando isso ocorre, atinge o coração do sistema capitalista, em uma situação difícil de controlar.

O ideal seria ter, no passado, a supervisão dos produtos que o mercado estava gerando, o que não seria algo fácil, pois o capitalismo depende de dois fatores: demanda efetiva e inovação. A intervenção do estado não pode matar a inovação, mas, por outro lado, não pode ser relaxada, como foi nos últimos anos, deixando o capitalismo à própria sorte. Em suma, deve haver um equilíbrio entre o intervencionismo estatal e a liberdade necessária para que os agentes econômicos possam desenvolver o capitalismo.

Além disso, deve-se ter menos fé na capacidade dos economistas fazerem previsões. Menos fé na mitigação de riscos através de modelos sofisticados e produtos financeiros. O que se percebe é que nem os grandes bancos de investimento, que estavam vendendo esses produtos, tinham pleno conhecimento sobre os riscos que estavam vendendo ou comprando. Os modelos de risco existentes são bastante sofisticados e necessários, mas insuficientes. É preciso ponderar quando há um problema localizado ou um problema global.

Não foi por falta de educação, mas por um excesso de pessoas brilhantes que o mundo entrou nessa crise. Essas pessoas criaram produtos financeiros muito sofisticados, como os derivativos aos quais o Professor Marcos Eugênio concede o status de grandes atores da crise, já que permitem uma alavancagem gigantesca e tornam mais difícil avaliar o valor do investimento.

$\mathrm{Na}$ opinião do entrevistado, o Fed agiu corretamente com sua política de taxas de juros. O grande vilão da crise não foram as taxas de juros, mas o capitalismo deixado à própria sorte. As técnicas de mitigação de risco pareciam infalíveis. É a velha crise especulativa, que faz parte do sistema capitalista.

\section{Helio Nogueira da Cruz}

O Professor Hélio Nogueira da Cruz adota uma postura keynesiana e um pouco schumpeteriana, segundo ele mesmo. Sua visão é a de que o sistema capitalista é naturalmente sujeito a flutuações. A palavra ciclo pode não ser tão apropriada, pois dá uma ideia de periodicidade. Hélio acredita que é quase inevitável que seja assim, pois o mercado está sempre fazendo apostas sobre o futuro, e os erros fazem parte do contexto. Não é uma questão de informação, mas de previsão, e não há como fazer previsões totalmente acertadas, já que o futuro é incerto. 
O Professor de Economia fala que houve certa arrogância dos economistas, que acreditavam que não haveria mais crises, que os ciclos estavam domados. Hoje está claro que o problema das oscilações não está resolvido. Pelo contrário, o mundo entrou em uma crise das maiores já vistas.

Segundo o Professor, o sistema tem características que o tornam propenso a gerar oscilações. Uma delas é a possibilidade de o próprio sistema gerar moeda, através do crédito. Antes de falar das crises monetárias, Dr. Helio falou sobre crises não-monetárias. Entre essas, destacam-se as guerras ou eventos como o 11 de setembro americano, mas também merecem destaque eventos como o fim de um grande projeto. Um país que constrói pirâmides, por exemplo. De repente, a pirâmide está pronta. O soberano tem uma vida longa, e sua pirâmide já está pronta. O que fazer com os 40 mil empregados que trabalhavam nesta obra? O mesmo acontece com a construção de catedrais. Um grande número de trabalhadores é mobilizado para o projeto, e quando acaba a construção, o que fazer? Construir outra igreja? É assim que cidades como Salvador foram se enchendo de igrejas.

Por outro lado, existe o sistema bancário, financiando guerras, catedrais e outros projetos. Esse sistema tem a capacidade de gerar poder aquisitivo, e essa capacidade é regulada. A capacidade de o sistema ampliar o crédito gera uma potencial instabilidade, pois pode aumentar descontroladamente a demanda agregada, subir o nível de atividade econômica, e depois entrar em uma fase de baixas.

$\mathrm{Na}$ atual crise, os bancos, principalmente os bancos de investimento, geraram poder aquisitivo fora da área regulada, utilizando mecanismos que geram moeda ou "quase moeda", por meio de tecnologia e de instrumentos financeiros modernos. Então, falta de regulação e novos instrumentos financeiros ajudaram a criar uma bolha de crédito que, quando estourada, se espalhou por outros mercados além daqueles que, a exemplo dos Estados Unidos e de alguns países europeus, apostavam em ativos de alto risco.

A opinião do Professor Hélio é contrária ao uso do valor justo na contabilidade, pois o preço de mercado varia, e as técnicas de valuation são apenas expectativas, não refletindo verdadeiramente um "valor justo". Para ele, a contabilidade tradicional tem a vantagem de se basear em um valor exato: o custo histórico. No entanto, percebe que a contabilidade não teve nenhuma importância na deflagração ou difusão da crise, simplesmente porque a informação contábil não tem essa força. 


\section{Alkimar Moura}

Segundo Alkimar Moura, a política monetária frouxa dos Estados Unidos induziu a alavancagem dos bancos, aumentando seu apetite pelo risco. A China, com uma política cambial que mantinha sua moeda desvalorizada para gerar saldos comerciais, também contribuiu para o aumento de liquidez global, o que favoreceu a demanda por ativos de alto risco, o aumento de alavancagem e, em consequência, o afrouxamento das políticas de crédito. Segundo hipótese de Greenspan, esse fenômeno se concentrou nos Estados Unidos porque a China tinha maior propensão a poupar, e os americanos captaram esse excesso de poupança e investiram no mercado de hipotecas.

Existe uma dúvida sobre se a raiz da crise está mais relacionada com políticas governamentais, no favorecimento do acesso ao crédito para pessoas de baixa renda, ou com os bancos, que afrouxaram seus critérios na gestão de crédito.

Esse cenário incentivou uma mudança no modelo de negócios dos bancos, do tradicional originate and hold para o originate and distribuite. Tal sistema envolvia um broker, agente entre o tomador e o banco, o qual originava os créditos, mas não tinha preocupação com o risco; um banco de crédito, um banco de investimento, que empacotava e distribuía os ativos, um sistema de intermediação, investidores institucionais, e as seguradoras, que alocavam garantias de crédito aos instrumentos lastreados nos referidos ativos, conferindo maior segurança ao sistema.

As agências de rating certificaram milhares de operações geradas nesse sistema com a classificação AAA. Curiosamente, apenas doze empresas mundiais obtiveram classificação AAA, o que mostra que as empresas eram avaliadas com muito mais rigor do que esses ativos. Como o próprio emissor é quem paga pela avaliação do ativo, é preciso gerenciar esse conflito de interesses.

O sistema criou uma concentração de créditos de baixa qualidade, e esses créditos, apelidados de ativos tóxicos, se espalharam pelo mercado por meio de instrumentos de securitização.

Instrumentos como as CDO eram muito complexos para a decisão de investimento. Mais por um problema de opacidade desses ativos do que por culpa dos investidores.

Bem informado sobre o significado de fair value accounting, Alkimar complementou a questão 3 do roteiro de entrevista, informando que valor justo é o montante pelo qual um ativo 
poderia ser vendido ou um passivo liquidado em condições normais de mercado. O fair value escancara a realidade e, mesmo que tenha um caráter pró-cíclico, favorece uma solução mais rápida.

\section{Gustavo Loyola}

O ex-presidente do Banco Central Gustavo Loyola afirma que a atual crise tem como pano de fundo os sucessivos anos de elevada liquidez dos mercados financeiros, políticas monetárias relativamente expansionistas, que foram justificadas por um período de inflações muito baixas: o período da grande moderação. Os Bancos Centrais, focando as metas de inflação, se sentiram confortáveis em manter taxas de juros baixas, não se importando com os preços dos ativos financeiros.

A inflação baixa pode ser justificada por diversos fatores, sustenta o economista, entre eles a atuação da China no comércio mundial, o ganho de produtividade proporcionado pelo avanço tecnológico e a confiança nos Bancos Centrais. Esse ambiente de "fartura" leva a um comportamento menos avesso ao risco pelos agentes econômicos, isto é, esses stakeholders se tornam mais otimistas. Em tempos de exuberância, só existe memória do passado recente, e não dos tempos de maior risco, o que torna os investidores mais agressivos em termos de assunção de riscos.

Em resumo, o período de fundamentos macroeconômicos muito favoráveis, com taxas de juros baixas e inflação sob controle levou investidores a uma atitude de maior tolerância ao risco. Alguns fatores agravaram esse processo. O primeiro deles situa-se na linha dos incentivos. A gestão moderna dos bancos, especialmente dos bancos americanos, criou um sistema em que a sustentabilidade da instituição foi substituída pela busca de retornos de curto prazo, ou seja, era mais importante ter um resultado maior no exercício presente, e não necessariamente um resultado maior durante um período maior.

O processo de incentivos dentro dos bancos gerou uma primazia dos profissionais de negócio sobre os da área de risco, que eram vistos como "aqueles que queriam estragar a festa" e foram colocados em segundo plano.

Outro aspecto que agravou o problema, também no que se refere aos riscos, foi o uso não cauteloso e disseminado de modelos, em especial de modelos de VaR, que embutem uma memória do comportamento passado, seja para estabelecer correlações, volatilidades, etc., e a 
aceitação desses modelos sem crítica, sem que fossem feitos testes de estresse consistentes. Você acredita que o mundo vai se comportar da forma como se comportou ontem. Isso é algo recorrente no ser humano: você elimina os outliers, e o problema está justamente neles.

Para Loyola, outro aspecto relevante foi o relaxamento regulatório sobre a gestão de riscos. Os reguladores confiaram que as instituições geriam bem os seus riscos. Greenspan dizia que os maiores interessados em gerir bem seus riscos eram os próprios bancos e, portanto, o regulador deveria se basear nos próprios modelos de risco adotados pelo setor privado; porém, as pressões competitivas levaram os administradores a não priorizar o melhor gerenciamento de riscos.

Loyola acredita que a questão central no mercado norte-americano não é só o caminho para a desregulamentação, mas as maneiras que os stakeholders desenvolveram para burlar a regulamentação existente. Os bancos de investimento, o mercado de securitização, os instrumentos financeiros complexos e as operações em mercados de balcão foram largamente utilizados por sofrerem menor regulação.

Por fim, Loyola citou os problemas com o mercado de hipotecas e o modelo de originar créditos e distribuir, que era visto como uma maneira eficiente de pulverizar o risco, mas foi provado que os bancos mantinham parte do risco, da maneira como operavam, dando liquidez para fundos de investimento e intermediários financeiros, garantindo linhas de crédito justamente com os papéis securitizados. No momento em que esses títulos perdiam valor, os bancos acabavam recomprando os mesmos para evitar riscos de reputação ou mesmo por uma obrigação assumida.

Sobre o relacionamento entre os países em desenvolvimento e os países desenvolvidos, Loyola fez a seguinte proposição:

Divida o mundo em dois grupos de países: Grupo A e Grupo B, e suponha que esses países têm uma relação equilibrada. (Conforme a Figura 41).

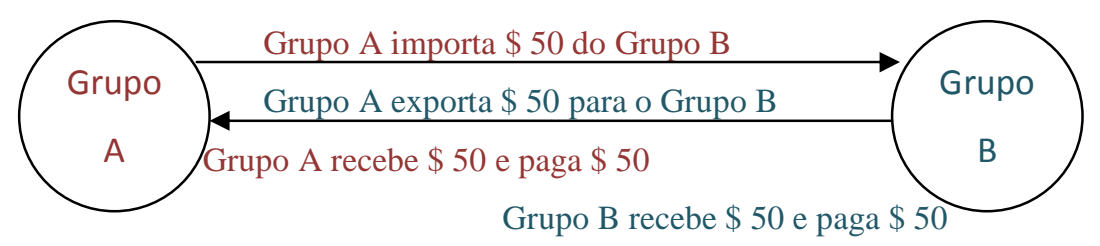

Figura 41: Relação equilibrada entre dois grupos de países 
Nessas condições, o nível de reservas dos dois grupos de países tenderia a zero.

Em uma segunda proposição (conforme Figura 42), o Grupo A importa \$ 100 do Grupo $\mathrm{B}$, que não importa nada do segundo grupo.

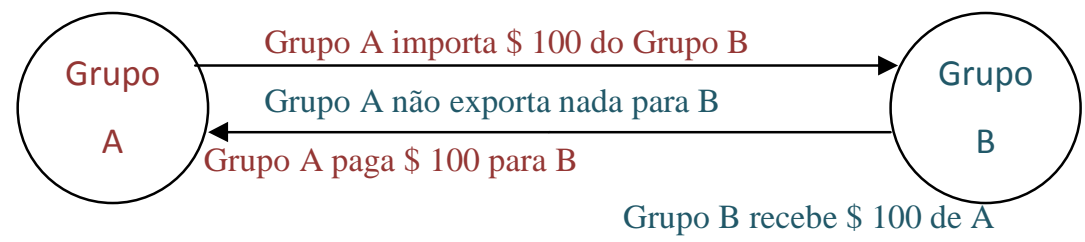

Figura 42: Relação não equilibrada entre dois grupos de países

Desta forma, o Grupo A torna-se devedor do Grupo B, que tende a acumular reservas. O Grupo A, devedor, consegue financiamento justamente com o Grupo B, que investe em ações, títulos e ativos dos países do Grupo A, criando em A um ambiente de liquidez.

A segunda proposição se assemelha a uma realidade recente no comércio mundial, onde os Estados Unidos, país que gasta mais do que a renda gerada internamente, pertenceriam ao Grupo A, enquanto China, Índia e Brasil pertenceriam ao Grupo B. Voltando à questão dos juros, se o Fed tivesse ajustado os juros nos Estados Unidos, provavelmente haveria redução do consumo e aumento da poupança, e, consequentemente, a redução do déficit em conta corrente deste país. Esta é outra maneira de observar o mesmo fenômeno.

\section{Clive Botelho}

Segundo Clive Botelho, Tesoureiro do Banco Pine, com a acentuação da globalização nas últimas décadas, o mundo experimentou um ganho de confiança em relação aos fatores de produção e uma abertura de veia de comércio sem precedentes. Por outro lado, foi fomentado um ciclo virtuoso na economia mundial que teve dois caminhos: $\mathrm{O}$ caminho de comércio exterior e o caminho de mercado de capitais. Trata-se de uma globalização com novos entrantes (China, Índia, etc.), a qual trouxe outra dinâmica para o mercado e contribuiu para que o PIB crescesse tanto. O capitalismo tornou-se único como força, e esses novos entrantes impactaram a alta das commodities e a percepção de investimento para uma demanda. 
O ambiente regulatório esteve relativamente frouxo, de acordo com Clive, pois esperavase que o mercado fizesse sua autorregulação e que os riscos pudessem ser minimizados através de instrumentos como os CDS.

Os bancos de investimento, relativamente menos regulados que os bancos comerciais, tiveram um papel importante na propagação da alavancagem. Além disso, Clive informa que o mercado experimentou um crescimento extraordinário de outros entes que faziam uma desintermediação com alavancagem.

De acordo com Clive, os Estados Unidos mantiveram uma política monetária muito frouxa, acreditando que a inflação estaria sob controle e também para tentar combater outros problemas que poderiam ter gerado quedas na atividade econômica, especialmente a crise da Nasdaq e os atentados de 11 de setembro de 2001.

Desregulamentação, intermediários pouco regulados, alavancagem através de instrumentos off-balance sheet, concentração dos CDS com poucos garantidores. Essa somatória de fatores fez o mundo crescer acima do PIB potencial e contribuiu para que o mercado financeiro ficasse muito acima da alavancagem ideal.

\section{Roberto Padovani}

O economista Roberto Padovani aponta duas origens principais para a atual crise financeira:

1. A política monetária frouxa dos Estados Unidos, no que tange às baixas taxas de juros, que permitiram que o país saísse da crise de 2001/2002, e entrasse em um período de expansão global.

2. A falta de regulação bancária nos Estados Unidos.

A combinação de um período longo de valorização de ativos, crescimento global e pouca regulação bancária nos Estados Unidos fez com que fosse construído o excesso de alavancagem, algo que é clássico e cíclico na economia mundial. Padovani lembra que nos últimos 100 anos as crises financeiras tiveram um padrão muito parecido, com um período de expansão econômica e valorização de ativos e tendo como característica comum o fato de que essa expansão geralmente veio acompanhada de alavancagem bancária.

O que detonou a crise, em sua opinião, foi a reversão da política monetária dos Estados Unidos, com a alta dos juros e o consequente aumento da inadimplência, que inicialmente não 
teve nada de significativo, mas que, devido à alta alavancagem dos bancos, passou a ser um componente grave.

O economista cita o livro Uma breve história da euforia financeira, de Galbraith, que fala sobre características comuns às grandes crises dos últimos séculos. Padovani diz que a descrição das crises passadas é exatamente a mesma da crise atual, e destaca que o papel da alavancagem foi fundamental nesses eventos.

Estimulado pelo entrevistador, Padovani falou sobre dois impactos da entrada dos BRIC no cenário das economias mais atuantes:

1. A entrada dos BRIC foi um fato novo, que tornaria este ciclo diferente dos demais. Esses novos motores de crescimento fizeram com que houvesse maior confiança na sustentação do ciclo.

2. Aumento da liquidez, já que as economias emergentes estavam dispostas a financiar seu maior cliente, os Estados Unidos.

Na opinião do economista, esses impactos existiram, mas foram secundários.

Outro fato novo - pergunta o entrevistador - poderia ser a disponibilidade de novos instrumentos financeiros? Padovani acredita que os juros baixos incentivaram as entidades a buscar maiores riscos, o que aconteceu por meio desses novos instrumentos financeiros e dos créditos subprime, e aconteceria com outros ativos de risco, caso não existissem os atuais.

Sobre os modelos de risco, Padovani diz que o problema não está na simplicidade ou complexidade dos mesmos, mas na tendência de seguirem um padrão baseado no passado. Nos últimos anos antes da crise, por exemplo, a baixa oscilação do mercado fez com que esses modelos projetassem um cenário com pouco estresse, o que pode ter reforçado a tendência de alavancagem dos bancos.

\section{Gustavo Franco}

De acordo com o economista Gustavo Franco, esta crise tem muitos enredos diferentes, começando com o problema do subprime, que já foi bastante estudado, e também com o conflito entre originadores de crédito e bancos, o que gerou grande parte do problema.

O cenário da crise possui um componente de regulação deficiente, especificamente para os originadores de crédito, e também para as operações de securitização. O originador é uma entidade comissionada que não tem nenhum interesse na qualidade do crédito, diferentemente do 
banco. Ele vende o empréstimo como se fosse um intermediário de venda a crédito, não importando se o mutuário vai pagar ou não, baseando seus critérios em um padrão mínimo, muito abaixo do que seria aceitável. Quando um potencial emprestador se enquadra no padrão mínimo, o crédito entra no sistema; o originador recebe sua comissão e não é mais incomodado por aquela concessão.

Esse episódio, segundo Gustavo Franco, é apenas parte do problema, que toca em algo muito mais profundo, que é um defeito estrutural do sistema americano, e tem relação com a responsabilidade limitada dos gestores e acionistas de instituições financeiras. No mercado americano, somente na ocorrência de fraudes os bens pessoais de acionistas e administradores são requeridos para a liquidação de uma instituição financeira. Comparando com o mercado brasileiro, um Ato de Intervenção do Banco Central do Brasil imediatamente torna indisponíveis os bens dos administradores. Desta forma, o sistema americano cria um incentivo perverso para correr riscos.

O ex-presidente do Banco Central acredita que a matriz comum de todas as sub-crises desta crise atual tem relação com correr riscos demais. Se os administradores não correm riscos, acreditam que podem jogar um jogo arriscado por anos, pois quando ganham, levam parte dos resultados para casa, e quando perdem, não têm seus bens ou seus ganhos anteriores sujeitos a risco. Quem perde é a empresa que ele administra. É evidente que, se esse jogo é jogado repetidamente, um dia vai dar errado. Segundo Gustavo Franco, talvez o jogo não tenha dado errado antes porque hoje existem ativos de altíssima octanagem, que permitem apostas envolvendo riscos catastróficos, o que há 10 anos não era possível. Já no início desta onda de ascensão dos derivativos, nos idos de 1998, a falência do LTCM foi a primeira demonstração de como os derivativos poderiam ser usados para o bem e para o mal.

A combinação de derivativos com operações estruturadas, inclusive fora de bancos, talvez tenha sido um dos grandes aspectos desta crise.

Resumindo: há um fator de base legal, no caso de problemas de continuidade no sistema bancário, e a disponibilidade de instrumentos que possibilitam o excesso de riscos. Correr riscos em excesso passou a ser possível em quase todas as áreas e acabou dando errado, quase numa reação em cadeia.

Perguntado pelo entrevistador sobre o impacto da política monetária americana na atual crise, Gustavo Franco respondeu que a política monetária expansionista de Greenspan é um fator 
muito menos relevante que os incentivos estruturais e as inovações financeiras, e complementou dizendo que as crises são sempre surpresas, mas após explicações, elas parecem evitáveis, quão boas são as explicações geradas a posteriori.

\section{Ilan Goldfajn}

Segundo o Professor Ilan Goldfajn, as raízes da crise, com seus exageros no momento da bonança, surgiram muito antes de 2007, quando os preços das hipotecas americanas começaram a cair. Então, o que era a crise do subprime, se tornou uma crise financeira, e hoje já é uma crise mundial. $\mathrm{O}$ problema não se resumiu às hipotecas americanas, houve também um excesso de otimismo em relação à capacidade de crescimento da economia e da valorização dos ativos, que ano após ano continuavam a crescer. E, no momento da euforia, os investidores acreditaram que não havia risco algum. Quando caiu o primeiro quadro, que foram as hipotecas, tudo o que veio depois acabou ruindo.

Em resumo, esta crise foi motivada por excesso de alavancagem, muita gente tomando muito risco sem perceber, uma crença de que os ativos não parariam de se valorizar, a percepção dos reguladores, agências de rating e Bancos Centrais, de que não era necessário ser tão rigoroso na regulação ou na política monetária.

O aumento do uso de derivativos e outros ativos complexos também foi um fato relevante porque produziu ativos muito opacos, difíceis de precificar, mas a culpa não seria dessas inovações. Esses instrumentos têm suas vantagens: ajudam a distribuir ou a realocar riscos. A questão é a limitação. Para tudo deve haver limites, e nos últimos tempos antes da crise esses limites foram ultrapassados.

\section{Mailson da Nóbrega}

Mailson da Nóbrega acredita que a crise de 2008 é uma crise de múltiplas causas; por isso, não aceita nenhuma explicação simplista, como da desregulamentação, que é bastante usada por alguns setores da esquerda. Na origem do problema, segundo ele, está um desequilíbrio macroeconômico mundial gerado pela emergência de um grupo de países, que por alguma razão se tornaram exportadores de capital. Esses países, entre eles a China, a Índia e, por algum momento, o Brasil, acumularam um grande volume de riqueza financeira, e esses recursos foram direcionados para a compra de papéis do Tesouro americano. 
E, como esses países não tinham uma tradição de investidores no exterior, ao contrário do que aconteceu no Reino Unido no Século XIX, nos Estados Unidos, Alemanha e outros países Europeus e Japão no Século XX e, mais recentemente, com e a Coreia do Sul, esses recursos eram vistos como uma espécie de seguro para lidar com crises externas e, portanto, a eles pouco importava a rentabilidade dos papéis nos quais eles investiam, a preferência era por papéis do Tesouro americano, e ela foi percebida pelo Greenspan quando ele falou de um enigma: como é que aumentam as taxas de curto prazo, enquanto as de longo prazo caem? E essas taxas caíam porque esses países compravam papéis. A China era o maior comprador de papéis do governo americano, e o Brasil se tornou o quinto, superando o Reino Unido. Então, essa situação criou um ambiente de ampla liquidez e baixas taxas de juros, um ambiente que no passado levou ao relaxamento da prudência e assunção de riscos elevados.

O fato de ter juros baixos e oferta de crédito levou o Presidente Clinton a propor ao Congresso dos Estados Unidos um relaxamento das regras de alavancagem da Fannie Mae e da Freddie Mac, que se tornaram grandes compradoras de hipotecas. Na visão dos políticos, naquela época, já que havia abundância de recursos para financiamento habitacional a custos muito baixos, era hora de os pobres terem acesso à casa própria; portanto, houve um incentivo à concessão de financiamento para devedores sem histórico de crédito. Por outro lado, entre os anos 1980 e 1990, a tecnologia e as inovações do mercado financeiro permitiram a disseminação do processo de securitização de recebíveis, que se generalizou no mundo inteiro, tornando-se uma característica do mercado de financiamento habitacional, sendo que, nos Estados Unidos, a securitização era feita quase sempre com total transferência do risco, ou seja, o originador na maioria das vezes não tinha nenhuma coobrigação. Esse foi um dos incentivos perversos para originar e distribuir, ou seja, quanto mais os originadores de crédito criassem operações, mais ganhariam. Portanto, houve uma tendência ao relaxamento dos critérios de concessão. Além disso, foram desenvolvidos os derivativos de crédito, como os Credit Default Swaps, que davam aos compradores dessas hipotecas uma segurança razoável de que, no caso de um atraso, o seguro pagaria por meio do derivativo. Esse tipo de operação levou à quebra de uma seguradora com a AIG.

Ao lado desses incentivos, crises no mercado imobiliário, pelo menos no registro pósSegunda Guerra Mundial, nunca tinham sido nacionais, o que dava ao papel hipotecário uma percepção de segurança maior do que outros papéis negociados no mercado financeiro e, 
portanto, todos os incentivos estavam criados para uma expansão irresponsável dos créditos subprime.

Existe um outro aspecto que um diretor do Bank of England, Andrew Haldane, chamou de "miopia frente ao desastre", em um paper. O estudo de Haldane mostra que, sempre que se distancia de um evento desastroso, há uma tendência humana de apagar da memória aquele evento e repeti-lo, ou contribuir para que ele se repita. É como os motoristas que reduzem a velocidade após presenciar um acidente mas tendem a acelerar conforme o desastre vai ficando mais distante em sua memória.

Desde os anos 80, os bancos começaram a desenvolver modelos sofisticados de gestão de risco. Primeiro foi criado o Value at Risk, depois foram modelos de stress test, o que foi criando a percepção de criação de um mundo ideal, com riscos controlados. O que fica claro hoje é que um ingrediente importante nesses modelos é o cenário, o qual tem um componente de subjetividade muito grande, pois quem faz o stress test precisa introduzir um cenário provável.

Também existe um incentivo perverso decorrente da forma de remuneração dos executivos de instituições financeiras, que eram bonificados pelo lucro das instituições, independentemente do fato de essas operações se tornarem ruinosas ou não no futuro.

Além dos incentivos criados para a expansão cada vez maior das operações de alto risco, como aconteceu em outras crises, as instituições financeiras encontraram maneiras de contornar as limitações à alavancagem. Um delas foi a criação dos SIV, verdadeiros bancos paralelos.

Então, a crise é uma conjugação de todos esses fatores, o que não isenta os executivos de bancos, os reguladores, etc. $\mathrm{O}$ que acontece é que o ambiente cria uma espécie de cegueira coletiva. Muitos perguntam por que os reguladores dos países desenvolvidos e os talentosos gestores de riscos de bancos não perceberam o problema antes. No caso dos bancos, os incentivos estavam errados, e no caso dos reguladores, historicamente eles não andam à frente dos desastres. Recentemente, alguns estudos mostraram que o sistema financeiro tem maior capacidade de atrair talentos do que o governo, de forma que existem mais talentos tentando contornar a regulação do que talentos tentando fechar essas portas. É o caso em que o xerife chega depois do bandido.

\section{Maria Helena Santana}

Maria Helena Santana apontou o afrouxamento da política de juros dos países desenvolvidos como um dos fatores que incentivaram a busca de rentabilidade por meio de 
investimentos com riscos maiores. $\mathrm{O}$ ambiente regulatório, em direção à desregulamentação, não estava preparado para prevenir ou controlar a evolução do mercado. Em sua opinião, há de ser repensado o equilíbrio entre a intervenção e a disciplina de mercado. $O$ crescimento descontrolado dos volumes de derivativos negociados no balcão, por exemplo, trouxe muito mais riscos e prejuízos do que benefícios sociais.

\section{Arminio Fraga}

O economista Arminio Fraga Neto acredita que esta crise tem elementos da família das "bolhas especulativas", mas também uma base real bastante clara. Segundo ele, o mundo vivia um momento histórico de grande importância, em uma fase de notória prosperidade, onde o mercado incorporou um grande número de pessoas, especialmente da China, da Índia, do Leste Europeu, e até do Brasil, que trabalhavam, poupavam e acrescentavam mais capital e eficiência ao mercado.

Este momento histórico veio acompanhado de certa ilusão de que os ciclos econômicos haviam sido dominados, no que foi chamado de "a grande moderação". Hoje também está claro, de acordo com o economista, que a administração de risco tinha se tornado, ilusoriamente, uma ciência exata, e prometia um grau de controle muito maior do que era possível na realidade. Outro problema é que muitas entidades utilizavam sistemas de administração de risco muito parecidos, o que individualmente pode ter sido uma decisão racional, mas coletivamente deixava de ser. Partindo de hipóteses simplificadoras, a administração de risco conduziu as entidades ao uso generalizado de técnicas como o VaR.

No campo regulatório, hoje é possível notar que medidas prudenciais poderiam ter sido tomadas, no sentido de não permitir um nível muito alto de alavancagem, assim como o descasamento de prazos entre ativos e passivos, no patamar em que o sistema financeiro vinha trabalhando.

Também teve relevância o uso disseminado de derivativos e instrumentos de securitização que não favoreciam a transparência, escondendo o grau de alavancagem das instituições, utilizando mecanismos off-balance sheet.

Tudo isso ajudou a criar e fazer crescer uma "bolha de crédito" e uma "bolha de preços de imóveis". A situação descolou-se consistentemente de uma realidade econômica, da forma como foi estudado por Hyman Minsky em Can "it" happen again?, onde Minsky se refere à crise de 
1929. Fraga também recomendou a leitura de Manias, panics and crashes, de Charles Kindleberger.

O estouro dessas bolhas acontece como em um estalar de dedos, quando todos percebem que estão na estratosfera, e somente após a ocorrência dos fatos. O mercado percebe que carecia de uma regulação contracíclica, menos dependente das agências de rating, e de uma contabilidade mais transparente, capaz de evidenciar os mecanismos de alavancagem utilizados pelas entidades.

Arminio Fraga está entre aqueles que não acreditam que é possível evitar totalmente os ciclos financeiros e econômicos. Para ele, as crises sempre podem acontecer, porém, este ciclo foi longe demais e desembocou em uma grande crise.

\section{Tereza Cristina Grossi Togni}

Teresa Grossi comentou a crise sob ótica de sua experiência profissional, como conhecedora de mercado financeiro e supervisora bancária, deixando fora da sua análise os fatores macroeconômicos.

A ex-diretora do Banco Central entende que a crise veio sendo preparada ao longo de anos, à medida que os Estados Unidos tinham uma estrutura de supervisão bancária pouco compreendida, com organismos de supervisão com mandatos sobrepostos, o que exigia desses organismos processos de coordenação muito complexos. Essa estrutura ainda excluía uma parcela significativa do sistema financeiro americano. Quando foi tomada a decisão de que os bancos de investimento ficariam fora da supervisão do Fed, provavelmente essas instituições ainda operavam como bancos de investimento puros. A partir de determinado momento, passaram a atuar fortemente como intermediadores.

Houve também decisões políticas, no sentido de tornar os Estados Unidos um ambiente pouco regulado, de forma que estimulasse o desenvolvimento dos mercados. Havia uma crença de que os próprios mercados se regulariam, com as forças de mercado atuando como reguladoras. No entanto, ficou provado que autorregulação só existe quando se tem incentivos para que ela funcione.

Desta forma, os supervisores não faziam o que deviam fazer, ou por que não tinham mandato, ou por que o processo de supervisão, da maneira como foi implementado, não permitia que se entrasse muito profundamente nas operações que os bancos estavam transacionando. 
Um mix de fatores como uma parte do sistema financeiro sem regulação, um sistema financeiro em que a governança corporativa não funcionou corretamente, e alguns incentivos negativos, como a remuneração de executivos, absurdamente elevada e baseada em metas de curtíssimo prazo foi o que preparou um cenário para essa crise.

Acompanhando os fatores de mercado, estão as escolhas políticas. A decisão de fazer empréstimos em massa para pessoas de renda mais baixa, sem procurar conhecer o cliente e entender sua capacidade de pagamento foi eminentemente política. E o processo desses empréstimos em massa foi concebido com incentivos perversos, pois à medida que agentes geravam operações de crédito, recebiam por isso e não carregavam mais os riscos.

É um emaranhado de coisas. O único componente que não teve nenhuma culpa na deflagração da crise foi a contabilidade a valor justo. Outro aspecto da contabilidade americana, especificamente os elementos off-balance sheet, contribuíram significativamente para a crise, pois por meio desses mecanismos algumas instituições esconderam tudo que se passava em veículos de investimento, mostrando um grau de alavancagem menor do que existia na realidade. Mais uma vez, uma falha de regulação. Não foi interpretação de norma, pois esta dizia claramente que veículos de investimento com características particulares não deviam ser consolidados.

Teresa Grossi conclui dizendo que não há um único causador, mas sim uma série de circunstâncias que levaram o sistema americano a uma crise financeira, que depois se alastrou pela Europa e pelo resto do mundo.

O gatilho que detonou a crise, transformando-a em uma crise mundial, segundo ela, foi a liquidação do Lehman, que surpreendeu fortemente os mercados, os quais reagiram muito rapidamente.

\section{Antônio Delfim Netto}

O Professor Delfim Netto começa sua tese sobre a crise falando sobre a fabulosa expansão econômica mundial que ocorreu no início deste século. As exportações, que antes cresciam em média $4 \%$, passaram a crescer cerca de $17 \%$. Nessa expansão, os países emergentes tiveram enorme vantagem, com suas exportações crescendo mais rapidamente, e suas dívidas, que eram avaliadas em dólares nominais, permanecendo em patamares estáveis. A situação dos emergentes melhorou muito, e isso pôde ser verificado nas reservas que acumularam. Isso aconteceu quando 
os Estados Unidos se transformaram em absorvedor de toda a produção mundial excedente, construindo um déficit em conta corrente de 5,7 trilhões de dólares.

Delfim afirma que a referida expansão não seria possível se não tivesse uma concomitante expansão do financiamento, pois desenvolvimento se faz com inovação e crédito. Do lado político, depois da crise de 2001, o governo americano teve a generosa ideia de financiar casas para quem não poderia pagar, o que não poderia ter acabado de forma diferente. Não é verdade que a crise foi uma completa surpresa, pois desde 2004 há estudos acadêmicos mostrando que, se o preço das casas caísse, aconteceria uma tragédia. Mais do que isso, há estudos que estimavam o nível da tragédia. Isso foi ignorado por uma combinação de sofisticação financeira, já que muitos imaginavam que haviam encontrado mecanismos que previam e calculavam corretamente os riscos, com uma taxa de juros muito baixa e uma incapacidade dos Bancos Centrais de acompanhar essas inovações financeiras. Foram criados instrumentos que utilizavam equações diferenciais e estocásticas, e como ninguém sabia como funcionavam esses instrumentos, que apesar de complexos, eram (segundo o entrevistado) pacotes recheados de lixo, tendiam a comprá-los simplesmente porque continham o selo do Lehman Brothers.

Segundo o Dr. Delfim, é importante lembrar que, desde o início, os financistas que criaram as principais fórmulas de mensuração de risco diziam que delas não poderiam ser extraídas conclusões generalizadas. Uma avaliação de risco individual jamais funcionaria no caso de acontecer um movimento de manada. Também é preciso citar a incapacidade da autoridade monetária de entender as consequências da utilização de modelos de risco nas situações em que o risco é coletivo e não individual.

O sistema bancário, de acordo com Delfim Netto, é uma rede que envolve o crédito interbancário e outros milhões de fatores entre bancos, empresas e pessoas. Quando é retirado um ponto da rede, ela desmonta, e foi isso que aconteceu com a liquidação do Lehman Brothers. Estava tudo muito ruim, mas quando caiu o Lehman Brothers, o problema emergiu de maneira fantástica.

Após a eclosão da crise, muitos disseram que seria o fim do capitalismo. Isso não é verdade, pois o capitalismo é um processo de seleção histórico, que foi sendo construído pelo homem através dos tempos. É um sistema que combina eficiência produtiva com liberdade. É claro que o sistema não é perfeito, pois o homem quer igualdade, e é por isso que é necessário o Estado para combinar esses elementos. 
O efeito de avaliar um ativo pelo valor de mercado, na opinião do Professor Delfim Netto, não teve nenhum papel relevante na deflagração ou agravamento da crise. A possibilidade de fazer operações fora do balanço, isso sim, foi um problema. Foi esse tipo de truque que permitiu que os riscos fossem encobertos. A avaliação a mercado é fundamental para calcular riscos corretamente, mesmo que, tecnicamente, ainda tenha muitos problemas. É um componente bastante sensível, pois é uma contabilidade onde o patrimônio flutua diariamente, e não há dúvida de que este é um mecanismo muito mais útil para o investidor.

Questão 2: Em resumo, quais dos fatores inventariados abaixo colaboraram para deflagrar, e/ou agravar a atual crise financeira? Assinale nas duas colunas, indicando uma pontuação de 0 a 3 , onde 3 pontos representa os fatores com maior relevância e 0 pontos representa os fatores irrelevantes. As respostas possíveis para cada item da questão 2 são 0,1,2 e 3. Para apresentação final, estas foram agrupadas em ordem decrescente, de acordo com sua média. Foram criados três grupos, os quais numericamente intercalam as quatro respostas possíveis para esta questão, conforme a Figura 43:

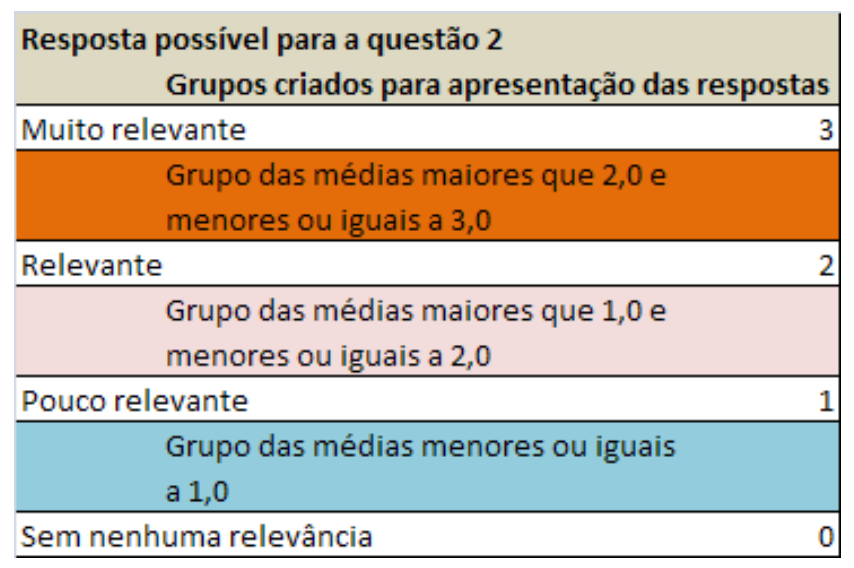

Figura 43: Agrupamentos para apresentação da questão 2

Desta forma, as Figuras 44, 45 e 46 mostram fatores que colaboraram com a deflagração da crise, sendo que cada uma das três ilustra respectivamente aspectos classificados como "muito relevante", "relevante" e "pouco relevante". As figuras 47, 48 e 49 têm função análoga, mas tratam de fatores que colaboraram com o agravamento da crise. 


\begin{tabular}{|l|r|r|r|}
$\begin{array}{l}\text { FATORES QUE COLABORARAM COM A DEFLAGRAÇÃO DA CRISE } \\
\text { GLOBAL - MÉDIA MAIOR QUE 2,0 }\end{array}$ & MÉDIA & MEDIANA & MODA \\
\hline $\begin{array}{l}\text { Incentivos dos Bancos para seus gestores, que faz com que } \\
\text { assumam maiores riscos. }\end{array}$ & 2,33 & 3 & 3 \\
\hline $\begin{array}{l}\text { Regulação deficiente. } \\
\text { Incentivos do Governo Norte-americano para a expansão do } \\
\text { crédito imobiliário. }\end{array}$ & 2,25 & 2,5 & 3 \\
\hline $\begin{array}{l}\text { Excesso de liquidez mundial } \\
\text { Incentivos do FED para os participantes do mercado (Politicas } \\
\text { de taxas de juros). }\end{array}$ & 2,17 & 2 & 2 \\
\hline Supervisão deficiente. & 2,17 & 2 & 3 \\
\hline
\end{tabular}

Figura 44: Fatores mais relevantes para a deflagração da crise

\begin{tabular}{|l|r|r|r|}
$\begin{array}{l}\text { FATORES QUE COLABORARAM COM A DEFLAGRAÇÃO DA CRISE } \\
\text { GLOBAL - MÉDIA MENOR OU IGUAL A 2,0 E MAIOR QUE 1,0 }\end{array}$ & MÉDIA & MEDIANA & MODA \\
\hline $\begin{array}{l}\text { Transações de Bancos com setores menos regulados, como os } \\
\text { hedge funds. }\end{array}$ & 1,83 & 2 & 3 \\
\hline Agências de rating não cumpriram o seu papel. & 1,75 & 1,5 & 1 \\
\hline Investidores mal informados. & 1,50 & 1,5 & 0 \\
\hline Complexidade dos produtos financeiros modernos. & 1,42 & 1,5 & 1 \\
\hline Globalização e liberalização dos mercados. & 1,42 & 1 & 1 \\
\hline Diretrizes de Basiléia II para gerenciamento de riscos. & 1,33 & 1,5 & 2 \\
\hline Deficiências nos processos de auditoria. & 1,17 & 1 & 1 \\
\hline
\end{tabular}

Figura 45: Fatores de média relevância para a deflagração da crise

\begin{tabular}{|l|r|r|r|}
$\begin{array}{l}\text { FATORES QUE COLABORARAM COM A DEFLAGRAÇÃO DA CRISE } \\
\text { GLOBAL - MÉDIA MENOR OU IGUAL A 1,0 }\end{array}$ & MÉDIA & MEDIANA & MODA \\
\hline $\begin{array}{l}\text { Modelos de risco muito complexos (Charles Goodhart diz que os } \\
\text { modelos são muito complexos, mas que falta bom senso. A } \\
\text { solução seria modelos mais simples e diretos). }\end{array}$ & 0,92 & 1 & 1 \\
\hline $\begin{array}{l}\text { Modelos de risco muito simples (Greenspan diz que esses } \\
\text { modelos são muito simples para captar o conjunto das variáveis } \\
\text { que governam a realidade). }\end{array}$ & & & \\
\hline $\begin{array}{l}\text { Regras de contabilidade do FASB ou IASB (Fair value } \\
\text { accounting). }\end{array}$ & $\mathbf{0 , 6 7}$ & $\mathbf{0 , 5}$ & $\mathbf{1}$ \\
\hline
\end{tabular}

Figura 46: Fatores menos relevantes para a deflagração da crise 


\begin{tabular}{l|r|r|r|}
$\begin{array}{l}\text { FATORES QUE COLABORARAM COM O AGRAVAMENTO DA CRISE } \\
\text { GLOBAL - MÉDIA MAIOR QUE 2,0 }\end{array}$ & MÉDIA & MEDIANA & MODA \\
\hline $\begin{array}{l}\text { Transações de Bancos com setores menos regulados, como os } \\
\text { hedge funds. }\end{array}$ & 2,25 & 2,5 & 3 \\
\hline $\begin{array}{l}\text { Regulação deficiente. } \\
\text { Globalização e liberalização dos mercados. }\end{array}$ & 2,08 & 2,5 & 3 \\
\hline $\begin{array}{l}\text { Incentivos dos Bancos para seus gestores, que faz com que } \\
\text { assumam maiores riscos. }\end{array}$ & 2,00 & 2,5 & 3 \\
\hline Supervisão deficiente. & 2,00 & 2 & 2 \\
\hline Complexidade dos produtos financeiros modernos. & 2,00 & 2 & 2 \\
\hline
\end{tabular}

Figura 47: Fatores mais relevantes para o agravamento da crise

\begin{tabular}{|c|c|c|c|}
\hline $\begin{array}{l}\text { FATORES QUE COLABORARAM COM O AGRAVAMENTO DA CRISE } \\
\text { GLOBAL - MÉDIA MENOR OU IGUAL A 2,0 E MAIOR QUE 1,0 }\end{array}$ & MÉDIA & MEDIANA & MODA \\
\hline Excesso de liquidez mundial & 1,92 & 2 & 2 \\
\hline $\begin{array}{l}\text { Incentivos do FED para os participantes do mercado (Politicas de } \\
\text { taxas de juros). }\end{array}$ & 1,83 & 2 & 2 \\
\hline Agências de rating não cumpriram o seu papel. & 1,75 & 2 & 1 \\
\hline Investidores mal informados. & 1,75 & 2 & 2 \\
\hline $\begin{array}{l}\text { Incentivos do Governo Norte-americano para a expansão do } \\
\text { crédito imobiliário. }\end{array}$ & 1,58 & 2 & 2 \\
\hline $\begin{array}{l}\text { Modelos de risco muito simples (Greenspan diz que esses modelos } \\
\text { são muito simples para captar o conjunto das variáveis que } \\
\text { governam a realidade). }\end{array}$ & 1,50 & 2 & 2 \\
\hline $\begin{array}{l}\text { Regras de contabilidade do FASB ou IASB (Fair value } \\
\text { accounting). }\end{array}$ & 1,50 & 2 & 2 \\
\hline Diretrizes de Basiléia II para gerenciamento de riscos. & 1,08 & 1 & 1 \\
\hline $\begin{array}{l}\text { Modelos de risco muito complexos (Charles Goodhart diz que os } \\
\text { modelos são muito complexos, mas que falta bom senso. A } \\
\text { solução seria modelos mais simples e diretos). }\end{array}$ & 1,08 & 1] & 1 \\
\hline
\end{tabular}

Figura 48: Fatores de média relevância para o agravamento da crise

\begin{tabular}{|l|r|r|r|}
$\begin{array}{c}\text { FATORES QUE COLABORARAM COM O AGRAVAMENTO DA CRISE } \\
\text { GLOBAL - MÉDIA MENOR OU IGUAL A 1,0 }\end{array}$ & MÉDIA & MEDIANA & MODA \\
\hline Deficiências nos processos de auditoria. & 0,92 & 1 & 1 \\
\hline
\end{tabular}

Figura 49: Fatores menos relevantes para o agravamento da crise

Questão 3: Qual o melhor significado para "fair value accounting", na sua opinião? 


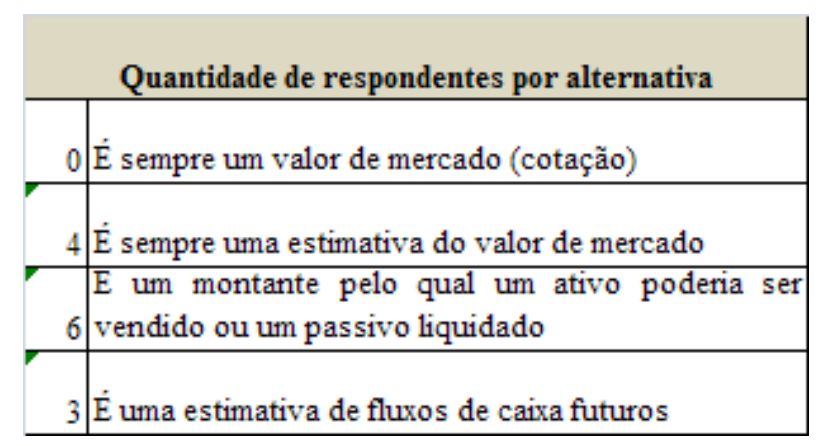

Figura 50: Significado de fair value accounting

A tendência que pode ser observada com auxílio da tabela da Figura 50 é de que o grupo entrevistado percebe o valor justo muito mais como uma estimativa ou expectativa do que propriamente como um valor de mercado. Apesar de, muitas vezes, o próprio valor de mercado (cotação) representar o valor justo, entendê-lo como uma estimativa ou expectativa de fluxos futuros é benéfico, pois mostra que o usuário bem informado não acredita cegamente neste valor. Ora, se um valor foi gerado por estimativa, é preciso conhecer premissas e critérios de valuation para, então, acreditar no número.

Questão 4: Alguns críticos da contabilidade pelo valor justo têm falado que ela cria um efeito espiral, à medida que expõe o valor recuperável do ativo a cada vez que este valor é reduzido, criando um novo patamar para as próximas negociações. Qual o seu nível de concordância ou discordância com esta visão?

\begin{tabular}{|r|l|}
\multicolumn{2}{|c|}{ Quantidade de respondentes por alternativa } \\
\hline 2 & Concordo totalmente \\
\hline 8 & Mais concordo do que discordo \\
\hline 1 & Mais discordo do que concordo \\
\hline 2 & Discordo totalmente \\
\hline
\end{tabular}

Figura 51: Concordância com efeito pró-cíclico da contabilidade a valor justo

Através da tabela da Figura 51, conclui-se que a grande maioria dos entrevistados possui um nível de concordância alto com a afirmação de que a contabilidade a valor justo tem efeito pró-cíclico. Apesar de concordar com a afirmação, no geral, os entrevistados entendem que a informação gerada pela contabilidade a valor justo é fundamental para os investidores. Através da questão 2, pôde-se perceber que, apesar de reconhecerem o efeito espiral mencionado na questão 
4, os profissionais entrevistados acreditam que a contabilidade a valor justo teve um peso muito pequeno no agravamento, e ainda menor na deflagração da crise.

Questão 5: A atual crise provavelmente seria descoberta mais tardiamente, caso os bancos norteamericanos e europeus não utilizassem uma contabilidade baseada no valor justo. Qual o seu nível de concordância ou discordância em relação a esta afirmação?

\begin{tabular}{r|l|}
\multicolumn{2}{|c|}{ Quantidade de respondentes por alternativa } \\
\hline 3 & Concordo totalmente \\
\hline 7 & Mais concordo do que discordo \\
\hline 0 & Mais discordo do que concordo \\
\hline 3 & Discordo totalmente \\
\hline
\end{tabular}

Figura 52: Concordância com proposição: a crise seria descoberta mais tardiamente, sem fair value accounting

A proposição da questão 5 foi aceita pela maioria dos entrevistados, que entendem que a contabilidade a valor justo dá maior transparência ao processo de evidenciação, e tende a agilizar a descoberta de focos de crise, conforme ilustra a Figura 52.

Questão 6: Contabilizar um ativo financeiro pelo valor justo significa reconhecer nos balanços o seu valor de mercado, quando existe um mercado líquido para este ativo, ou um valor estimado, que pode ser baseado em transações recentes com ativos semelhantes, técnicas de valuation, como modelos de precificação de opções ou fluxo de caixa descontado. Você acredita que a contabilidade baseada no valor justo colaborou com o agravamento da crise financeira?

\begin{tabular}{|r|l|}
\multicolumn{2}{|c|}{ Quantidade de respondentes por alternativa } \\
\hline 0 & Concordo totalmente \\
\hline 6 & Mais concordo do que discordo \\
\hline 2 & Mais discordo do que concordo \\
\hline 5 & Discordo totalmente \\
\hline
\end{tabular}

Figura 53: Concordância com a proposição de que a contabilidade a valor justo agravou a crise

Em linha com a questão 4, a tabela da Figura 53 mostra que quase metade dos entrevistados concordam que a contabilidade colaborou com o agravamento da crise. No entanto, um elemento a mais do que a metade dos entrevistados tem opinião diferente, com o agravante de que 5 pessoas discordaram totalmente da proposição. Uma conclusão a respeito da questão de 
pesquisa deve levar em conta o conjunto deste roteiro de entrevista, pois o conjunto de respostas para a questão 6 isoladamente pode não ser conclusivo.

Questão 7: Mesmo que a contabilidade não mostrasse este valor, as tesourarias das instituições financeiras já acompanhavam e calculavam o preço dos ativos financeiros que faziam parte de suas carteiras. Desta forma, você concorda ou discorda que, mesmo sem ofair value accounting, o efeito dos preços sobre a crise seria semelhante?

\begin{tabular}{r|l|}
\multicolumn{2}{|c|}{ Quantidade de respondentes por alternativa } \\
\hline 5 & Concordo totalmente \\
\hline 5 & Mais concordo do que discordo \\
\hline 2 & Mais discordo do que concordo \\
\hline 1 & Discordo totalmente \\
\hline
\end{tabular}

Figura 54: Concordância com a proposição de que sem o valor justo o efeito dos preços sobre a crise seria semelhante

Pela tabela da Figura 54, é possível notar a tendência dos entrevistados para a concordância com a proposição da questão 7. Alguns entrevistados, no entanto, colocaram ressalvas na sua resposta, informando que, sem a contabilidade a valor justo, é provável que a informação sobre os preços demorasse mais para sair das tesourarias e chegar no mercado.

\subsection{Limitações da pesquisa}

Talvez a maior entre as limitações desta pesquisa seja o tamanho da amostra utilizada. Por este motivo, a seleção dos nomes dos entrevistados teve de ser bastante criteriosa, focada somente em profissionais que ocuparam ou ocupam posições de destaque no governo e/ou no mercado financeiro. Desta forma, cabe ressaltar que as opiniões aqui relatadas não devem ser generalizadas, mas analisadas como opiniões de grandes conhecedores do mercado.

Por tratar de um tema bastante recente, a revisão de literatura teve de respeitar a data de corte de 31 de janeiro de 2009. Devido à relevância das publicações, foram abertas exceções para materiais do FASB e do IASB, em especial o discussion paper sobre fair value accounting do IASB, publicado no final de maio deste ano. 


\section{CONCLUSÕES}

Pelo grande número de publicações posteriores à crise a respeito da contabilidade a valor justo, e pelas discussões que foram abertas, é possível deduzir que a crise global serviu como um stress test desse critério de mensuração.

$\mathrm{Na}$ concepção deste trabalho, foi percebida a necessidade de entender bem a conceituação e a aplicação do valor justo. Mercado ativo, venda não-forçada, liquidez, risco de crédito, cotações, técnicas de valuation e outras considerações foram colocadas dentro de um contexto teórico.

Sobre a crise financeira mundial, impactaram fatores macroeconômicos, como a política de juros do Fed e a ascensão econômica dos BRIC, que irrigaram o mundo desenvolvido com seu excesso de reservas; novos produtos financeiros, que ajudaram a criar liquidez para certos instrumentos financeiros e aumentaram a complexidade de precificação e controles; falhas de regulação e supervisão; falha na atuação das agências de rating; incentivos dos bancos para seus gestores, que eram remunerados por assumir cada vez mais riscos; incentivos do governo norteamericano para a expansão do crédito e consequente criação de um sistema baseado em incentivos perversos.

$\mathrm{Na}$ opinião do autor deste estudo, e de acordo com economistas que publicaram livros ou artigos recentes, onde são apontados fatores que dispararam o gatilho da crise, a contabilidade a valor justo não teve um papel decisivo na deflagração da crise financeira, e tampouco poderia ter evitado a mesma.

No entanto, alguns nomes citados neste trabalho afirmam que essas novas normas de contabilidade podem, sim, ter agravado os efeitos da crise, uma vez que criam novos patamares de negociação a cada revisão das bases de mensuração de um ativo ou passivo. Assim, ao evidenciar a verdade, a contabilidade estaria atuando de maneira pró-cíclica. Um dos benefícios da contabilidade a valor justo é justamente trazer aos investidores externos algumas informações que antes só estavam disponíveis para aqueles que dispunham de informações internas da entidade.

Ao lado da contabilidade a valor justo, os contadores que defendem o aumento da relevância da informação, em detrimento de um maior grau de objetividade, informam que a 
contabilidade a valor justo, em essência, é o que busca o mercado, porém, o que não falta é espaço para a evolução das técnicas de valuation. Manter um ativo financeiro por um valor muito superior ao valor que a entidade receberia no caso da venda deste ativo não seria um bom modelo de transparência.

Desta forma, pode-se concluir que o problema não reside em mensurar um ativo ou passivo pelo valor justo, mas sim em como chegar a este valor. Com quais premissas e com quais técnicas a informação foi construída? Existe um valor de mercado para o ativo ou passivo avaliado? Ora, se não existe um mercado, por que utilizar uma cotação, em vez de uma técnica que estime com maior confiabilidade o valor do ativo ou do passivo? É justamente esse o ponto: O valor de mercado é apenas uma das formas de se chegar ao valor justo, e, apesar de ser a mais utilizada, não devem ser desprezadas as demais técnicas de mensuração.

Recentemente, SEC, FASB e IASB estudaram este assunto. Concluíram que a contabilidade a valor justo não esteve entre as causas primárias da crise financeira mundial, e ainda que os investidores entendem esta como uma informação importante para a sua tomada de decisões. O resultado global do nosso teste empírico corrobora esta conclusão. Os especialistas consultados, na sua totalidade, não consideram que a contabilidade a valor justo tenha contribuído para a deflagração da crise e, à exceção de um dos entrevistados, todos os demais entendem a utilidade desta informação contábil.

Alguns entrevistados, no entanto, consideram que a contabilidade a valor justo é prócíclica, e portanto poderia agravar ou acelerar os efeitos de uma crise. Ainda que tenham assumido este fato explicitamente na questão 4 do roteiro de entrevista, as respostas da questão 6 mostraram que não há consenso quanto a esta afirmação. Ainda, quando comparados com outros dezesseis fatores, o critério de mensuração foi classificado entre os que produziram menor efeito na crise financeira mundial.

No geral, os economistas e especialistas entrevistados possuíam um bom entendimento do que é contabilidade a valor justo, diferenciando esse tipo de mensuração de um simples valor de mercado, e a maioria deles entendeu que a crise global talvez fosse descoberta mais tardiamente, caso os bancos não utilizassem uma contabilidade baseada no valor justo. 


\section{BIBLIOGRAFIA}

ABOODY, David; BARTH, Mary; KASZNIK, Ron. SFAS No. 123 Stock-Based Compensation Expense and Equity Market Values. The Accounting Review. V.79, p. 251-2756, 2004.

ARAÚJO, Adriana M. P. de; ASSAF NETO, Alexandre. A contabilidade tradicional e a contabilidade baseada em valor. Revista de Contabilidade e Finanças da USP, n. 33, 2003.

ASSAF NETO, Alexandre. Contabilidade Baseada em Valor. São Paulo: Anais do VI Congresso Brasileiro de Custos, FEA-USP, julho/1999.

BANCO SANTANDER. Manual de precificação. Área de Riscos de Mercado e Precificação, junho/2008.

BANCO DO BRASIL. Manual de marcação a mercado. BBDTVM. Janeiro/2007.

BARTH, Mary. Fair value accounting: Evidence from investment securities and the market valuation of banks. The Accounting Review. V.69, p. 1-25, 1994.

BARTH, Mary; BEAVER, William; LANDSMAN, Wayne. The Relevance of Value Relevance Literature for Financial Accounting Standard Setting: Another View. Journal of Accounting and Economics. V.31, p.77-104, 2001.

BARTH, Mary; LANDSMAN, Wayne. Fundamental Issues Related to Using Fair Value Accounting for Financial Reporting. Accounting Horizons. V.9, p. 97-107, 1995.

BARTH, Mary; LANDSMAN, Wayne, WAHLEN, James. Fair Value Accounting: Effects on banks' Earnings Volatility, Regulatory Capital, and Value of Contractual Cash Flows. Journal of Banking \& Finance. V.19, p. 577-605, 1995.

BEAVER, William; DEMSKI, Joe. The Nature of Income Measurement. The Accounting Review. V. 54, p. 38-46, 1979.

BONFIM, Antulio N. Derivativos de créditos e outros instrumentos. Rio de Janeiro: Elsevier, 2007.

BOOKSTABER, Richard. Mercado Financeiro: a crise anunciada: mercados, fundos de hedge e os perigos da inovação financeira. Rio de Janeiro: Elsevier, 2008. 
CARTA DO IBRE - Instituto Brasileiro de Economia da FGV. Crise financeira e Copom: O tanque monetário está cheio. Revista Conjuntura Econômica, n. 11, 2008.

CARVALHO, Nelson. Fair value: um salto no escuro. Disponível em http://analisedebalanco.blogspot.com/2008/10/fair-value-um-salto-no-escuro-diz-o.html. Acesso em 04/01/2009.

CRC SP - Os Princípios Fundamentais de Contabilidade, as Normas Brasileiras de Contabilidade e o Código de Ética Profissional do Contabilista. CONSELHO REGIONAL DE CONTABILIDADE DO ESTADO DE SP. 26 ed. São Paulo: CRC SP, 1999.

COELHO, Antonio; CARVALHO, Nelson. Análise Conceitual de Lucro Abrangente e Lucro Operacional Corrente: Evidências no Setor Financeiro Brasileiro. Brazilian Business Review. V.4, p.119-139, 2007.

DARÓS, Leandro Luis; BORBA, José Alonso. Evidenciação de Instrumentos Financeiros Derivativos nas Demonstrações Contábeis: Uma Análise das Empresas Brasileiras. Revista de Contabilidade e Finanças da USP, n. 39, 2005.

DENZIN, Norman K; LINCOLN, Yvona S. O Planejamento da Pesquisa Qualitativa: Teorias e Abordagens. 2a . ed. Porto Alegre: Artmed, 2006.

EL-ERIAN, Mohamed A. Mercados em colisão: Como entender a crise e traçar estratégias para uma era de mudança na economia global. São Paulo: Ediouro, 2008.

ERNST\&YOUNG. IFRS Stakeholder Series: How fair is fair value? Londres: 2005.

ERNST\&YOUNG. Fair Value Measurements: The impact for financial instruments. Londres: 2007.

Financial Accounting Standards Board (FASB). Fasb Staff Position FSP FAS 157-4. 2009

Financial Accounting Standards Board (FASB). Statement of Financial Accounting Concepts No.1- Objective of Financial Reporting by Business Enterprises. 1978

Financial Accounting Standards Board (FASB). Statement of Financial Accounting Concepts No.2- Qualitative Characteristics of Accounting Information. 1980.

Financial Accounting Standards Board (FASB). SFAS 107 - Disclosures about Fair Value of Financial Instruments, 1991.

Financial Accounting Standards Board (FASB). SFAS 130 - Reporting Comprehensive Income, 1997. 
Financial Accounting Standards Board (FASB). SFAS 133 - Accounting for Derivative Instruments and Hedging Activities. 1998.

Financial Accounting Standards Board (FASB). SFAS 157 - Fair Value Measurements. 1999. Financial Accounting Standards Board (FASB). SFAS 159 - The Fair Value Option for Financial Assets and Financial Liabilities, 2007.

GALBRAITH, John Kenneth. Galbraith Essencial. São Paulo: Futura, 2007.

GAMBOA, Celso; DANTAS, Roberto. Treinamento de Derivativos ministrado no Banco Pine. São Paulo, 2008.

GOODHART, Charles. A crise financeira global - Entrevista de L. Pinheiro Ronci. Revista Conjuntura Econômica, n. 11, 2008.

GREENSPAN, Alan. A era da turbulência: Aventuras em um novo mundo. Rio de Janeiro: Elsevier, 2008.

Group of North American Insurance Enterprises (GNAIE). Insurances say fair value accounting measurements were "powerful accelerant" to worldwide credit crisis. New York: 2008.

HENDRIKSEN, E. \& VAN BREDA, M. F. Teoria da Contabilidade. $8^{\text {a }}$ ed. São Paulo: Atlas, 1999.

HOLTHAUSEN, Robert; WATTS, Ross. The Relevance of the Value-Relevance Literature for Financial Accounting Standard Setting. Journal of Accounting and Economics. V.31, p.3-75, 2001.

International Accounting Standards Board (IASB). IAS 39 - Financial Instruments. 2005.

International Accounting Standards Board (IASB). Discussion Paper - Fair Value Measurements. 2007.

International Accounting Standards Board (IASB). Exposure Draft - Fair Value Measurements. 2009.

IUDÍCIBUS, Sérgio de; MARTINS, Eliseu. Uma investigação e uma proposição sobre o conceito e o uso do valor justo. Revista de Contabilidade e Finanças da USP, n. 44, 2007. Teoria da Contabilidade. $8^{\text {a }}$. ed. São Paulo: Atlas, 2006. 
MARTINS, Eliseu; CARVALHO, Luís N. Contabilidade: Aspectos Relevantes da Epopeia de sua Evolução. São Paulo. Revista de Contabilidade e Finanças da USP, n. 38, 2005.

KEYNES, John Maynard. A teoria geral do emprego, do juro e da moeda. São Paulo: Atlas, 1982.

KING, Alfred M. Fair Value for Financial Reporting: Meeting the New FASB Requirements. New Jersey: Wiley, 2006.

KPMG. Defining issues: New Statement Allows Fair Value Measurement for Financial Assets and Liabilities. 2007.

KPMG. Insights into IFRS. Edição 2005/2006, Thomson, 2005.

KRUGMAN, Paul. The return of depression economics and the crisis of 2008. New York: Norton, 2008.

LAKATOS, Eva Maria; MARCONI, Marina de Andrade. Fundamentos da Metodologia Científica. 6 ${ }^{\text {a }}$ ed. São Paulo: Atlas, 2008.

LENDO MEUS PENSAMENTOS. Proposta pela Agrenco e Interesse dos Minoritários. Disponível em http://www.lerpensamentos.com/2008/07/proposta-pela-agrenco-e-interessesdos.html. Acesso em: 23/11/2008.

LIMA, Gerlando Augusto Sampaio Franco de. Utilização da teoria de divulgação para avaliação da relação do nível de disclosure com o custo da dívida das empresas brasileiras. São Paulo, 2007. Tese (Doutorado em Ciências Contábeis) - Programa de Pós-Graduação em Ciências Contábeis da Faculdade de Economia, Administração e Contabilidade da Universidade de São Paulo.

LISBOA, Lázaro P.; PIGATTO, José A. M.; COSTA, Fábio M. da. "Valor Justo" em Contabilidade. Anais do XVI Congresso Brasileiro de Contabilidade, 2000.

LOPES, Alexsandro Broedel; GALDI, Fernando Caio. Returns to Value Investing: Fundamentals or Limits to Arbitrage? Social Science Research Network (SSRN), 2008.

Palestra "Derivativos: contabilização e implicações das operações na crise atual". São Paulo: Fipecafi, 14/11/2008.

MARD, Michael J; Hitchner, James R.; Hyden, Steven D. Valuation for Financial Reporting: The determination of fair value for audited intangible assets. $2^{\mathrm{a}}$. ed. New Jersey: Wiley, 2007. 
MARTINS, Eliseu. Avaliação de Empresas: Da Mensuração Contábil à Econômica. São Paulo: Atlas, 2001.

MONTEIRO, José C. Peréa; GUEVARA-GRATERON, Iván Ricardo. Impacto de la Aplicación del Fair Value en la Volatilidad de la Banca Brasileña: Un Estudio Empírico. Revista de Contabilidade e Finanças da USP, n. 40, 2006.

MOURA, Alkimar. Apontamentos para o novo século. Revista Conjuntura Econômica, n. 11, 2008.

NAKANO, Yoshiaki. Origens e consequências. Revista Conjuntura Econômica, n. 11, 2008.

NELSON, Karen. Fair value accounting for commercial banks: An empirical analysis of SFAS No. 107. The Accounting Review. V. 71, p.161-183, 1996.

PEStAnA, Maria H.; GAGEIRO, João N. Análise de Dados para Ciências Sociais: A Complementaridade do SPSS. $2^{\mathrm{a}}$. ed. Lisboa: Edições Sílabo, 2000.

PRESIDÊNCIA DA REPÚBLICA, Casa Civil - Sub-Chefia para Assuntos Jurídicos. Lei $\mathbf{N}^{\mathbf{0}}$ 11.638, de 28 dezembro de 2007.

PRICEWATERHOUSECOPPERS. Measuring Assets and Liabilities. Investment professionlas views. 2007a. Disponível em http://www.pwc.com/uk/eng/inssol/issues/pwc_measure-asset-liabil_mar07.pdf. Acesso em: 20/12/2007.

PRICEWATERHOUSECOPPERS. Has the dust settled yet?, 2007b. Disponível em http://www.pwc.co.uk/eng/publications/ifrs_has_the_dust_settled_yet.html. Acesso em: 20122007 .

RICARDO, David. Princípios de Economia Política e de Tributação. Lisboa: Fundação Calouste Gulbenkian, 2001.

SÁ, Antônio Lopes de. Ajustes Contábeis e Valor Justo. Disponível em http://www.acionista.com.br/mercado/artigos_mercado/190908_antonio_lopes.htm. Acesso em $\underline{23 / 11 / 2008}$.

Securities Exchange Commission (SEC). Report and Recommendations Pursuant to Section 133 of the Emergency Economic Stabilization Act. 2008.

Contabilidade - Justo valor e crise nos mercados. http://neopatrimonialismo.blogspot.com/search/label/Fair\%20Value. Acesso em 21/11/2008. 
SHILLER, Robert. The subprime solution: how today's global financial crisis hapennend, and what to do about it. New Jersey: Princeton University Press, 2008.

SHORTRIDGE, Rebecca T.; SCHROEDER, Amanda; WAGONER, Erin. Fair Value Accounting. The CPA Journal. New York: 2006.

SIEGEL, Sidney; CASTELLAN Jr, N. John. Estatística Não-Paramétrica para Ciências do Comportamento. $2^{\mathrm{a}}$. ed. Porto Alegre: Artmed, 2006.

SOROS, George. O novo paradigma para os mercados financeiros: a crise atual e o que ela significa. Rio de Janeiro: Agir, 2008.

SMITH, Adam. A Riqueza das Nações. São Paulo: Martins Fontes, 2003. 2ª ed. Rio de Janeiro: BestSeller, 2008.

STIGLITZ, Joseph E. Rumo a um novo paradigma. São Paulo: Francis, 2004.

TALEB, Nassim. A lógica do cisne negro: $O$ impacto do altamente improvável.

THE ECONOMIST. All's fair: The crisis and fair-value accounting. Disponível em http://www.economist.com/finance/displaystory.cfm?story_id=12274096. Acesso em: $16 / 11 / 2008$.

TROMBETTA, Rosa et al. Uma Análise Qualitativa do Disclosure de Títulos e Valores Mobiliários das Instituições Financeiras Brasileiras Mensurados a Fair Value. Anais do VII Congresso Usp de Contabilidade e Controladoria. 2007.

VÉRON, Nicolas. Fair value accounting is the wrong scapegoat for the crisis. Paris: 2008. WELFORT, Elionor. O Brasil e a Harmonização Contábil Internacional. São Paulo: Atlas, 2005.

WOLF, Martin. A reconstrução do sistema financeiro global. Rio de Janeiro: Elsevier, 2009.

YOKOI, Yuki. Contabilidade Injusta? Revista Capital Aberto, n. 63, 2008.

YOUNG, Michael R. Fair Value Accounting and Subprime. http://www.willkie.com/files/tbl_s29Publications\%5CFileUpload5686\%5C2566\%5CFair\%20Val ue\%20Accounting\%20and\%20Subprime.pdf. Acesso em 02/11/2008. 


\section{APÊNDICE A - CURRICULUM RESUMIDO DOS ENTREVISTADOS}

\section{Marcos Eugênio da Silva}

Possui graduação pela Universidade de São Paulo (1977) Mestrado em Economia pela Universidade de São Paulo (1982), Doutorado em Economia pela Universidade de São Paulo (1988) e pós-doutorado pela University of California (1990). Atualmente, é Professor Doutor da Universidade de São Paulo. Tem experiência na área de Economia Monetária e Fiscal.

\section{Hélio Nogueira da Cruz}

Possui graduação em Economia pela Universidade de São Paulo (1971), Mestrado em Economia pela Universidade de São Paulo (1975) e Doutorado em Economia pela Universidade de São Paulo (1977). Atualmente é professor titular da Universidade de São Paulo, membro de conselho da Fundação do Desenvolvimento Administrativo, membro - Núcleo de Política e Gestão Tecnológica da Universidade de São Paulo, - Secretaria da Ciência, Tecnologia e Desenvolvimento Econômico e membro do conselho da Fundação Instituto de Pesquisas Econômicas. Tem experiência na área de Economia, com ênfase em Mudança Tecnológica e Desenvolvimento Econômico.

\section{Alkimar Ribeiro Moura}

Possui graduação em Economia pela Universidade Federal de Minas Gerais (1963), Mestrado em Economia - University of California (1966) e Doutorado em Economia - Stanford University (1978). Atualmente é conselheiro independente na BSM - Bovespa Supervisão de Mercado e professor titular da Fundação Getulio Vargas - SP. Tem experiência na área de Economia, com ênfase em Economia e Política Monetária, atuando principalmente nos seguintes temas: economia do sistema financeiro, política monetária, mercado monetário, financeiro e de capitais, e finanças internacionais. Anteriormente, foi Vice-Presidente de Finanças e Mercado de Capitais do Banco do Brasil, Diretor de Normas, Diretor de Política Monetária e Diretor de Dívida Pública e Operações de Mercado do Banco Central do Brasil. 


\section{Gustavo Loyola}

Graduado pela Universidade de Brasília, mestre e doutor em economia pela FGV, e ex-presidente do Banco Central do Brasil, cargo que ocupou em dois períodos distintos. Foi diretor operacional da Planibanc Corretora de Valores de novembro de 1987 a janeiro de 1989 e diretor-adjunto do Banco de Investimento Planibanc S.A. de fevereiro a outubro de 1989. No Banco Central, exerceu o cargo de diretor de Normas do Mercado Financeiro e chefe do Departamento de Normas do Mercado de Capitais (1990-1992). Em seguida se tornou o presidente do Banco Central (novembro de 1992 a março de 1993). Retornou ao cargo de presidente em junho de 1995, permanecendo até agosto de 1997. Foi sócio e diretor da empresa MCM Consultores Associados de agosto de 1993 a maio de 1995. Exerceu a presidência do conselho fiscal do Banco Itaú Holding Financeira S.A. entre março de 2003 e abril de 2006. Atualmente, é sóciodiretor da Tendências Consultoria Integrada.

\section{Clive Botelho}

Atua no mercado financeiro há mais de 25 anos, tento ocupado posições executivas no Banco Santos, Standard Bank, Dresdner Bank Brasil e WestLB. Atualmente é CFO do Banco Pine. É formado em Engenharia pela Universidade Federal de São Carlos e em Administração pela Universidade Presbiteriana Mackenzie. Cursou MBA pelo Ibmec.

\section{Roberto Padovani}

Formado em Economia pela Universidade de São Paulo - USP - e em Administração pela Fundação Getúlio Vargas - FGV, com Mestrado em Economia também pela FGV.

Padovani coordena a área de estratégia e pesquisa para América Latina do Banco WestLB.

Foi analista de investimentos do Banco Safra, de 1988 a 1991, e, depois de concluir seu mestrado - 1991 a 1993, trabalhou como assessor do Ministério da Fazenda, em Brasília, na formulação e implementação do Plano Real, entre 1993 e 1995. Após ter sido diretor de pesquisa do Banco Fonte (1995 / 1996), foi sócio-diretor da Tendências Consultoria, onde trabalhou de 1996 a 2006.

\section{Gustavo Franco}

Graduou-se e cursou Mestrado em economia pela PUC-Rio. Fez Doutorado Universidade de Harvard, onde estudou a hiperinflação sofrida nos anos vinte pela Alemanha, Polônia, Áustria e 
Hungria, tese que venceu o Prêmio Haralambos Simionides da ANPEC, em 1987, para a melhor tese ou livro de economia.

Durante 1993-1999, foi secretário de política econômica adjunto do Ministério da Fazenda, Diretor de Assuntos Internacionais e Presidente do Banco Central do Brasil. A partir de sua experiência de governo publicou os livros: O Plano Real e Outros Ensaios; e O Desafio Brasileiro: ensaios sobre desenvolvimento, globalização e moeda.

Em 2000, fundou a Rio Bravo Investimentos. Participa de diversos conselhos de administração, consultivos e de eventos corporativos como palestrante. Mantém alguma atividade acadêmica (aulas e pesquisas) e escreve para jornais e revistas (O Estado de São Paulo, Jornal do Brasil, Veja, Época).

\section{Ilan Goldfajn}

Graduou-se em Economia pela UFRJ, fez Mestrado na PUC-Rio e Doutorado no MIT Massachusetts Institute of Technology.

Atualmente, é professor de Economia da PUC-Rio, Diretor do Instituto de Ensino e Pesquisa em Economia da Casa das Garças (IEPE/CdG) e Economista do Itaú-Unibanco.

Foi sócio da Ciano Investimentos e da Gávea Investimentos, Diretor de Política Econômica do Banco Central do Brasil, e também trabalhou no Fundo Monetário Internacional e na Universidade de Brandeis, em Massachussetts. Atuou como consultor para diversas organizações internacionais, como o Banco Mundial, o FMI e as Nações Unidas, além de governos e empresas do setor privado.

\section{Mailson da Nóbrega}

Graduou-se em economia em 1974 pela Faculdade de Ciências Econômicas, Contábeis e de Administração do Distrito Federal.

Funcionário do Banco do Brasil desde 1963, foi assessor da presidência (1974), chefe da Divisão de Análise de Projetos (1975) e chefe da Consultoria Técnica (1976). Em 1977, foi cedido ao Ministério da Indústria e Comércio para assumir o cargo de coordenador de Assuntos Econômicos. Em 1979, passou a exercer o mesmo cargo no Ministério da Fazenda, do qual mais tarde se tornou secretário-geral (1983). Entre 1985 e 1987, exerceu o cargo de diretor-executivo do European Brazilian Bank - Eurobraz, representando o Banco do Brasil. Em 1987, assumiu 
novamente a secretaria-geral do Ministério da Fazenda, tornando-se Ministro em 1988. Foi um dos fundadores da MCM Consultores Associados (1990) e da Tendências Consultoria Integrada (1997), da qual continua sócio. Participa do conselho de administração de diversas empresas no Brasil e no exterior e é colunista quinzenal da revista Veja.

\section{Maria Helena Santana}

Formada em Economia pela Faculdade de Economia, Administração e Contabilidade da Universidade de São Paulo - USP, Maria Helena Santana, desde julho de 2007, é Presidente da Comissão de Valores Mobiliários - CVM, onde ocupou, a partir de 2006, o cargo de Diretora. No período entre 1994 e 2006, desempenhou a função de Superintendente de Relações com Empresas e Gerente de Projetos Especiais na Bolsa de Valores de São Paulo - BOVESPA. Também foi Vice-Presidente do Instituto Brasileiro de Governança Corporativa - IBGC - até 2006 e membro do conselho de administração desde 2001. É Membro da Roundtable LatinoAmericana de Governança Corporativa da OCDE - Banco Mundial desde 2000.

\section{Arminio Fraga Neto}

Graduou-se e obteve Mestrado em Economia na PUC-Rio. Obteve Doutorado na Universidade de Princeton.

É sócio da Gávea Investimentos e Presidente do Conselho de Administração da BM\&F-Bovespa. Foi Presidente do Banco Central do Brasil, de 1 de março de 1999 a 17 de janeiro de 2003. Anteriormente, foi Diretor-gerente da Soros Funds Management LCC, membro da Junta de Diretores e Diretor do Departamento de Assuntos Internacionais do Banco Central do Brasil; trabalhou na Salomon Brothers e no Banco Garantia, lecionou na Escola de Assuntos Internacionais da Universidade de Colúmbia, na Escola Wharton, na PUC-Rio e na PósGraduação da FGV-Rio.

\section{Tereza Cristina Grossi Togni}

Bacharel em Administração de Empresas e Ciências Contábeis pela Universidade Católica de Minas Gerais. Diretora de Fiscalização do Banco Central do Brasil no período de 2000 a 2003, após carreira de 20 anos na instituição. Membro do Conselho de Administração do Banco Itaú 
Holding Financeira S.A de fevereiro de 2004 a novembro 2008. Especialista Financeira do Comitê de Auditoria do Itaú Unibanco Holding S.A. desde julho 2004.

\section{Antônio Delfim Netto}

Graduou-se em Economia na FEA-USP. Iniciou carreira acadêmica como professor assistente de Estatística Geral e Econômica logo depois de formado. Obteve o título de doutor com uma tese sobre o café. Em 1958, tornou-se catedrático da USP, onde permanece como professor aposentado.

Foi Ministro da Fazenda e principal artífice do chamado "milagre brasileiro" (1968-1973), quando o Produto Nacional Bruto crescia, em média, 10\% ao ano. Delfim é um liberal, membro da corrente monetarista, que prega o controle severo da emissão de dinheiro como forma de evitar inflação.

No governo Geisel, foi nomeado embaixador brasileiro na França (1974-1979). No governo Figueiredo, foi Ministro da Agricultura (1979) e, pouco depois, assumiu o Ministério do Planejamento.

Delfim iniciou a carreira parlamentar na Assembleia Constituinte de 1986 e elegeu-se deputado federal outras quatro vezes, sempre pelo mesmo grupo político, embora o partido tenha mudado de sigla várias vezes (PDS, 1980-1993; PPR, 1993-1995; PPB, 1995-2003; PP, de 2003 em diante). 


\section{APÊNDICE B - ROTEIRO DE ENTREVISTA}

1. Em sua opinião, como a atual crise financeira foi preparada? Cite os fatores que, em sua opinião, foram fundamentais para a deflagração da crise e, em segunda instância, o que faltou para que seus efeitos negativos pudessem ser evitados.

2. Em resumo, quais dos fatores inventariados abaixo colaboraram para deflagrar, acelerar e/ou agravar a atual crise financeira? Assinale nas duas colunas, indicando uma pontuação de 0 a 3 , onde 3 pontos representa os fatores com maior relevância e 0 pontos representa os fatores sem nenhuma relevância.

0 - Sem nenhuma relevância

1 - Pouco relevante;

2 - Relevante;

3 - Muito relevante.

\begin{tabular}{|l|l|l|}
\hline \multicolumn{1}{|c|}{ Fator } & \multicolumn{1}{|c|}{ Deflagrar } & \multicolumn{1}{|c|}{ Agravar } \\
\hline Finanças & & \\
\hline $\begin{array}{l}\text { Complexidade dos produtos financeiros } \\
\text { modernos. }\end{array}$ & \\
\hline $\begin{array}{l}\text { Modelos de risco muito complexos (Charles } \\
\text { Goodhart diz que os modelos são muito } \\
\text { complexos, mas que falta bom senso. A } \\
\text { solução seriam modelos mais simples e }\end{array}$ & & \\
diretos). & & \\
\hline $\begin{array}{l}\text { Modelos de risco muito simples (Greenspan } \\
\text { diz que esses modelos são muito simples para } \\
\text { captar o conjunto das variáveis que governam }\end{array}$ & & \\
a realidade). & & \\
\hline Regulação e Supervisão & & \\
\hline
\end{tabular}




\begin{tabular}{|l|l|l|}
\hline Regulação deficiente. & \multicolumn{2}{|l|}{} \\
\hline Supervisão deficiente. & & \\
\hline Deficiências nos processos de auditoria. & & \\
\hline $\begin{array}{l}\text { Diretrizes de Basileia II para gerenciamento } \\
\text { de riscos. }\end{array}$ & & \\
\hline $\begin{array}{l}\text { Agências de rating não cumpriram o seu } \\
\text { papel. }\end{array}$ & & \\
\hline $\begin{array}{l}\text { Regras de contabilidade do FASB ou IASB } \\
\text { (Fair value accounting). }\end{array}$ & & \\
\hline Fatores Macroeconômicos & & \\
\hline Excesso de liquidez mundial & & \\
\hline Globalização e liberalização dos mercados. & & \\
\hline Políticas & & \\
\hline $\begin{array}{l}\text { Incentivos dos bancos para seus gestores, que } \\
\text { fazem com que assumam maiores riscos. }\end{array}$ & & \\
\hline $\begin{array}{l}\text { Incentivos do Governo Norte-americano para } \\
\text { a expansão do crédito imobiliário. }\end{array}$ & & \\
\hline $\begin{array}{l}\text { Incentivos do Fed para os participantes do } \\
\text { mercado (políticas de taxas de juros). }\end{array}$ & & \\
\hline Outros & & \\
\hline regulados, como os hedge funds. & & \\
\hline Investidores mal informados. & & \\
\hline Fatores não inventariados & & \\
\hline Outros fatores não inventariado nesta lista & & \\
\hline
\end{tabular}

3. Qual o melhor significado para "fair value accounting", em sua opinião?

( ） É sempre um valor de mercado (cotação)

( ) É sempre uma estimativa do valor de mercado

( ) É um montante pelo qual um ativo poderia ser vendido ou um passivo liquidado 
( ) É uma estimativa de fluxos de caixa futuros

4. Alguns críticos da contabilidade pelo valor justo têm falado que ela cria um efeito espiral, à medida que expõe o valor recuperável do ativo a cada vez que este valor é reduzido, criando um novo patamar para as próximas negociações. Qual é o seu nível de concordância ou discordância com esta visão?

( ) Concordo totalmente

( ) Mais concordo do que discordo

( ) Mais discordo do que concordo

( ) Discordo totalmente

5. A atual crise provavelmente seria descoberta mais tardiamente, caso os bancos norteamericanos e europeus não utilizassem uma contabilidade baseada no valor justo. Qual é o seu nível de concordância ou discordância em relação a esta afirmação?

( ) Concordo totalmente

( ) Mais concordo do que discordo

( ) Mais discordo do que concordo

( ) Discordo totalmente

6. Contabilizar um ativo financeiro pelo valor justo significa reconhecer nos balanços o seu valor de mercado, quando existe um mercado líquido para este ativo, ou um valor estimado, que pode ser baseado em transações recentes com ativos semelhantes, técnicas de valuation, como modelos de precificação de opções ou fluxo de caixa descontado. Você acredita que a contabilidade baseada no valor justo colaborou com o agravamento da crise financeira?

( ) Concordo totalmente

( ) Mais concordo do que discordo

( ) Mais discordo do que concordo 
( ) Discordo totalmente

7. Mesmo que a contabilidade não mostrasse este valor, as tesourarias das instituições financeiras já acompanhavam e calculavam o preço dos ativos financeiros que faziam parte de suas carteiras. Desta forma, você concorda ou discorda que, mesmo sem o fair value accounting, o efeito dos preços sobre a crise seria semelhante?
( ) Concordo totalmente
( ) Mais concordo do que discordo
( ) Mais discordo do que concordo
( ) Discordo totalmente 